\title{
Arte fotográfica e estética moderna: sob o olhar do fotoclube de Goiânia
}

\begin{abstract}
Ana Rita Vidica Fernandes ${ }^{1}$
RESUMO: $\bigcirc$ artigo trata da discussão sobre arte fotográfica no movimento fotoclubista, a partir das produções textual e fotográfica, realizadas nas décadas de 1970-1980 por fotoclubes brasileiros, presentes no acervo do Clube da Objetiva (CO), fotoclube de Goiânia, Goiás, além de entrevistas com integrantes desse fotoclube. A produção fotográfica é vista, principalmente, através de fotografias selecionadas pelo referido fotoclube e veiculadas nos cinco Salões Nacionais de Arte Fotográfica que promoveu. Neste texto, as imagens selecionadas priorizam àquelas cuja apresentação visual dialoga com a estética moderna, utilizando como parâmetro a produção fotográfica dos pioneiros do Cine Fotoclube Bandeirante, de São Paulo, iniciador, no Brasil, das experimentações fotográficas modernas. Para isso, tenta-se fazer entender o fotoclube de Goiânia enquanto instituição fotoamadora, em seu contexto local e no âmbito do movimento fotoclubista, e na sua condição de seletor de fotografias artísticas.

PALAVRAS-CHAVES: Fotografia artística. Estética moderna. Fotoclube. Goiânia.

ABSTRACT: This article will treat the discussion of photographic art in photo-club movement, from the textual and photographic productions, performed by Brazilians photo-clubs, present the achievements of the Clube da Objetiva (CO), Goiania's photo-club, in the decades from 1970 to 1980, plus interviews with members of the CO. The photographic production will be seen mainly through photographs selected by that photo-club and broadcast in five National Photographic Art exhibits, which promoted. The selected images, in this text, prioritize those whose visual presentation dialogues with the modern aesthetic, utilizing the production of photographic Pioneers of the Cine Fotoclube Bandeirante, São Paulo's photo-club, pioneer in modern trials. For this, it is the understanding Goiania's photo-club in their local context and within the photo-club movement as an institution and its condition selector art photographs. KEYWORDS: Artistic photography. Modern aesthetic. Photo-club. Goiânia.
\end{abstract}

1. Docente da Universidade Federal de Goiás. E-mail: <anavidica@gmail.com>. 
2. Primeiro contato realizado pela pesquisadora em jun. de 2005, para a realização da dissertação de mestrado Clube da Objetiva (1970-89): um fotoclube no Central do Brasil, defendida em 2007 e desenvolvida no Programa de Pós-Graduação em Cultura Visual, da Faculdade de Artes Visuais da Universidade Federal de Goiás.

3. Essas palavras são atribuídas a Ruy Esteves (presidente do CO de 1972-1977) em matéria publicada em $\mathrm{OPO}$ pular. Ver Leila Daher Costa ([s. d.]). Desta matéria, foi encontrada, no acervo do CO, uma fotocópia também sem referência de data.
Papéis amassados e carcomidos, com palavras apagadas pelo tempo. $\bigcirc$ cheiro de lembranças e histórias esquecidas. Imagens de um passado que ficou distante. Mas que ainda pulsam em negativos e positivos, retratados por olhos ávidos por tornar visível o que viam e sentiam, e que materializavam através do disparo de suas manuais Rincon, Zenit, Nikon e tantas outras.

Alguns desses materiais acabaram se perdendo e ficando somente na memória dos integrantes do fotoclube de Goiânia, o Clube da Objetiva (CO). Contudo, os que resistiram ao tempo e foram guardados contam um pouco da história e da formação, tanto da instituição quanto da fotografia, inseridas na cultura da cidade.

Entrando uma sala empoeirada e abafada no fim de um dentre tantos corredores da Universidade Católica de Goiás, localizado na Faculdade de Arquitetura, foi feito o primeiro contato com estes materiais ${ }^{2}$. Entre panos de chão, vassouras, rodos e enceradeiras antigas, em um canto do apertado cômodo, estavam duas caixas enormes, cheias de esquecimento.

Ao abrir a primeira, um mundo, até então restrito às quatro paredes da caixa, também se abriu. Com grande curiosidade, os folderes, catálogos e correspondências foram sendo abertos e olhados sem grande profundidade, em um primeiro momento. Até que me deparei com o catálogo de um dos salões promovidos pelo Clube da Objetiva, o segundo, de 1978, como escrito na capa.

Folheando, vi reproduções fotográficas de outros fotoclubes. Na sua última página, esperando ver a continuidade dessas imagens, vários olhos me olharam nas fotografias dos integrantes do fotoclube de Goiânia, que participavam do salão em uma mostra paralela. O olhar penetrante de A menina dos Olhos, de Luiz Mauro Vasconcelos, os olhos tristes de $\bigcirc$ engraxate ou Mimetismo, de Cidinha Coutinho e de Odessa Arruda Hermano, respectivamente. De forma inusitada, os olhos da fotomontagem do casal Cenhor e Cenhoura, de Ruy Esteves.

Assim, aflorou uma ânsia de descobrir sobre este fotoclube. Então, vi um papel com a sua parte de cima rasgada, impossibilitando verificar sua data. Nele estava a pergunta: "O que é o Clube da Objetiva?" A primeira resposta é a de se tratar de um clube de fotografia, o que levava a explicação à pergunta; "O que se faz em um clube de fotografia?", e uma resposta: "Os fotoclubes são entidades que promovem o desenvolvimento dos processos fotográficos como arte. São locais onde uma fotografia é apresentada para crítica, com seu autor já preparado para ouvir opiniões que poderão ser frontalmente contrárias às suas, mas que têm como objetivo, sempre, uma crítica construtiva" ${ }^{3}$.

Além de as fotografias poderem ser mostradas dentro do próprio fotoclube, como exposto no texto, elas poderiam ser levadas para apreciação em outros fotoclubes. Nesse sentido, percebe-se que o Clube da Objetiva, apesar de estar localizado na cidade de Goiânia, mantinha relação com outras instituições do mesmo fim, que faziam parte de um movimento, o fotoclubismo.

Segundo Ângela Magalhães e Nadja Pelegrino, "o fotoclube se constituía num lugar ideal para o reconhecimento social dos aficcionados que 
participavam de concursos e saraus fotográficos, onde podiam mostrar a cultura adquirida em viagens pelo País e pelo exterior, e ainda habilidades artísticas"4.

Logo, o fotoclube constituía um espaço de troca de experiências fotográficas, em que havia a preocupação de uma produção artística, a partir de um intercâmbio entre os fotoclubes. Essa relação entre as associações caracterizava o movimento fotoclubista.

Outros questionamentos foram suscitados - Como o Clube da Objetiva faz parte deste movimento? Em que sentido se dá sua atuação no fotoclubismo brasileiro? Existiriam algumas características próprias que o diferenciariam dos demais? -, sobretudo ao ver aquelas caixas empoeiradas na sala quente e abafada da Faculdade de Arquitetura da referida universidade. Aqui tenta-se dar respostas a essas questões, pela construção da história do clube, a partir dos documentos de seu acervo, e do entendimento de alguns aspectos de seu funcionamento interno, para, posteriormente, verificar como se deu a construção visual do fotoclube.

Um breve histórico do Clube da Objetiva

No início dos anos 1970, a fotografia em Goiás, ainda incipiente, não dispunha de um local para a formação de fotógrafos, apesar da existência de profissionais e lojas comerciais nessa área ${ }^{5}$. Por tal razão, no ano de 1970, a Faculdade de Belas Artes e Arquitetura da Universidade Católica de Goiás cria o primeiro curso de fotografia de Goiânia. Com relação a essa iniciativa, há registro de depoimento do então diretor da faculdade, Amaury Menezes: "Achei que era oportuno para a Escola de Belas Artes e Arquitetura ter um fotoclube sediado ali dentro. Então cedemos os espaços para o clube usar, o laboratório, o estúdio e sala de aula. Foi um momento oportuno, tanto para a universidade enquanto instituição quanto para o clube como associação"b

O curso de Fotografia, a convite do diretor, era ministrado por Décio Marmo de Assis, chegado recentemente dos Estados Unidos, onde participara do fotoclube norte-americano Sierra Club, com sede em Yosemite, e da Associação de fotógrafos de São Francisco. A faculdade, inicialmente, cedia somente o espaço físico para o curso, sendo os equipamentos fotográficos levados pelo professor. Contudo, no ano seguinte, a Faculdade de Belas Artes e Arquitetura adquiriu os equipamentos necessários e absorveu definitivamente o curso, incorporando-o em suas atividades. No primeiro ano de existência o curso esteve estruturado, teoricamente, a partir do livro The Zone System, de Minor White, aluno de Ansel Adams?

Com a formação da primeira turma, no fim de 1970, os "recém-fotógrafos" sentiram necessidade de continuar praticando fotografia. Então, foi sugerida por Décio, e acatada pela turma, a ideia da formação de um fotoclube em Goiânia, já que a cidade não dispunha de espaços para a realização de reuniões e produções em torno da fotografia.
4. Cf. Ângela Magalhães $\mathrm{e}$ Nadja Pelegrino (2004, p. 36).

5. Não se sabe com certeza o número de lojas de fotografia da época, mas presume-se que existissem em torno de 17 lojas, como constam em cartas enviadas pelo $\mathrm{CO}$. Eram elas: Foto Taiwan; Hoffer Fotografias; Foto Luis; Cine Foto Fugiama; Equipe Aguinaldo Carlos; Foto Estúdio 7; Eletro Foto Baroni; Foto Ideal; Foto Amarante; Pepe Fotografias; Foto Eldorado; Foto Kazuo; Óticas Motta; e Sakamoto Sato.

6. Entrevista à autora, realizada no ateliê de Amaury Menezes (29 mar. 2006)

7. Informações dadas por Décio Marmo de Assis em entrevista à autora (22 maio 2006). 
8. Informações retiradas do Livro de Atas do Clube da Objetiva, inclusive a ordem dos nomes dos sócios-fundadores, presente no acervo do mesmo (Ata n. 1, 16 dez. 70).

9. Em entrevista à autora (maio 2006), Décio Marmo de Assis contou que, como nome do fotoclube, Ruy Esteves sugerira Zoom, que não foi escolhido. Décio, porém, aproveitou a ideia para o nome de sua loja de fotografia, a Zoom Fotografia e Publicidade, criada em 1974.

10. Apesar de o clube funcionar na Universidade Católica de Goiás em caráter provisório, houve reuniões nas casas de alguns membros como Ruy Esteves, Maria de Lourdes Pacheco, Fausto Rodrigues Valle ou mesmo em bares e restaurantes. E, em 1977 , aventou-se a possibilidade de utilizar o espaço do Parthenon Center para as reuniões, contudo foram realizadas poucas, devido à falta de segurança para os integrantes, que voltaram para a $\mathrm{Fa}$ culdade de Arquitetura. Atualmente, o clube ainda não tem sede, mas funciona na escola de fotografia da integrante Rosary Esteves, a Casa da Fotografia Rosary Esteves, com encontros quinzenais, aos sábados.

11. Os depoimentos foram colhidos em visitas aos integrantes, Amaury Menezes, Décio Marmo de Assis, Rosary Esteves e Ruy Esteves. Ver Referências.

12. Entrevista à autora, realizada no ateliê de Amaury Menezes (29 mar. 2006)

13. Cf. Helouise Costa e Renato Rodrigues da Silva (2004, p. 108).

14. Alberto Bacelar era membro da Abaf; na época, já há 24 anos.
Em 16 de dezembro de 1970, o Fotoclube de Goiânia foi fundado, em reunião que aconteceu na casa de Rosary Esteves, à rua 10, n. 250, Setor Oeste. Teve, como sócios-fundadores, Décio Marmo de Assis, José Amaury Menezes, Elder Rocha Lima, Beatriz Rocha Lima, Marilda Bastos de Assis, Rosary Caldas Esteves Pereira, Ruy Esteves Pereira, Lurdinha Pacheco, Joacy Eneida Côrtes, Antônio Martins Sobrinho, Fausto Rodrigues Valle, José Francisco Braga, Luiz Mauro Vasconcellos e Gratuli Nóbrega.

novo fotoclube passou a se chamar Clube da Objetiva9, nome proposto pelo membro Fausto Rodrigues e escolhido por votação nessa reunião de fundação. Na ocasião, além da escolha do nome, foram discutidos alguns pontos para a estruturação da embrionária associação fotográfica. Vale ressaltar, aqui, que o local decidido pelo clube para as suas reuniões foi a Escola de Arquitetura e Artes da Universidade Católica de Goiás ${ }^{10}$. Logo, o clube e o curso de fotografia da UCG acabam dividindo o mesmo espaço.

Com isso, pode-se dizer que, desde o nascimento do Clube da Objetiva, há uma relação entre ele e o curso de fotografia. Além da divisão do espaço, a maioria dos membros tinha passado pelo curso, que inclusive fora o responsável pelo agrupamento das pessoas, culminando na formação do fotoclube. Contudo, entre os participantes, há opiniões ${ }^{11}$ divergentes sobre tal relação. $\mathrm{Na}$ opinião de Amaury Menezes, "era uma relação tão umbilical, que a gente não sabia qual era o limite da faculdade de arquitetura, do curso de fotografia e, posteriormente, do Clube da Objetiva"12.

Rosary Esteves concorda que não havia separação clara, uma vez que a maioria dos integrantes do fotoclube advinha do curso, e completa dizendo que até a imprensa não fazia distinção entre um e outro. Décio Marmo de Assis até arrisca dizer que o clube se tornou um acessório do curso, mas que a associação ao curso também fora um meio de sobrevivência do clube, visto que havia um local de encontro e pessoas interessadas em participar. Apesar de haver grande concordância sobre esta relação, Ruy Esteves mostra uma opinião diferente, dizendo que "a separação era clara".

Embora não exista um consenso sobre o assunto, nos fotoclubes brasileiros era comum a relação com cursos de fotografia, que se dava, na maioria das vezes, de maneira inversa à que aconteceu no Clube da Objetiva, ou seja, era o fotoclube que originava o curso de fotografia. Com isso, essas associaç̃es forneciam mão-de-obra especializada para o mercado fotográfico, como expõem Helouise Costa e Renato Rodrigues da Silva: "Em busca de mão-de-obra especializada, este mercado precisou recorrer aos únicos cursos de fotografia existentes no Brasil, aqueles organizados pelos fotoclubes" 13 .

E mesmo que algum fotoclube não tenha tido - antes ou depois de sua criação - um curso regular de fotografia, era comum entre os fotoclubistas encarar a própria associação como um espaço de aprendizado: uma "escola de fotografia".

Nesta perspectiva, Alberto Bacelar ${ }^{14}$ escreve, em boletim informativo de jutho de 1977: 
Na minha opinião, acho o Foto Clube a maior escola de fotografia de uma cidade, e vou mais além: pouquíssimos ou quase nenhum profissional, dos bons, é claro, deixou de ser Sócio e frequentar por determinado tempo um Foto Clube. É no Foto Clube que se conhecem as tendências, as novidades, as criações e aberrações da fantástica arte fotográfica. Por melhor que seja o fotógrafo, frequentando um Foto Clube (eu disse um Foto Clube), vendo, ouvindo, sempre há algo a juntar aos seus conhecimentos. As dicas, honestas, como ajudaram nestes 24 anos de fotografia e de ABAF (nem podia deixar de ser)! Aprendi e aprendo até hoje, qualquer que seja o assunto, o detalhe, a viragem, a técnica, como poderia ter sido feito.

Com isso, fica clara a relação entre escola e fotoclube, não só no sentido de um curso formal de fotografia, mas principalmente quanto ao aprendizado realizado neste local. Logo, o Clube da Objetiva alinha-se aos demais fotoclubes, mesmo havendo uma inversão de como curso de fotografia e fotoclube se entrelaçaram.

Mas, sobre esta questão dos cursos de fotografia, houve um alinhamento posterior, uma vez que o CO passou também a oferecê-los. Mesmo não sendo permanentes, como os cursos do Foto Cine Clube Bandeirante ${ }^{15}$, de São Paulo, há informações de que, em 1979, o Clube da Objetiva teria promovido seu primeiro curso de fotografia para principiantes, ministrado por Décio Marmo de Assis, nos dias 2, 9, 16 e 23 de outubro, no auditório da Federação do Comércio ${ }^{16}$

Por meio de ofício à Federação do Comércio, o CO informa o deferimento da solicitação somente mediante pagamento. Apesar de não haver comprovação de que esse curso promovido pelo clube tenha sido ministrado, de fato já acontecera um Curso de Fotografia a cores, também oferecido por Décio Marmo de Assis, iniciado em 23 de março de 1980.

Apesar de, desde o início, o fotoclube de Goiânia parecer estar em consonância com as demais associações, através do alinhamento às práticas fotoclubistas, ele ainda não se inserira oficialmente no movimento. Para isso, logo no ano de fundação do CO, Décio Marmo de Assis, o presidente em exercício, viu a possibilidade de filiação à Confederação Brasileira de Fotografia e Cinema $(\mathrm{CBFC})^{17}$, entidade criada em 1950 ${ }^{18}$, que conseguiu reunir os fotoclubes do Brasil.

Como norma da CBFC $^{19}$, o fotoclube de Goiânia entrou como "aspirante à filiação"20, categoria em que permaneceu por 2 anos. Em 1974, como o clube tinha o mínimo de sócios (25), foi aceito como membro efetivo da Confederação, o que the concedeu o direito ao voto em reuniões, palestras, conferências e possibilitou a entrada na Sociedade de Fotógrafos Americanos $(P S A)^{21}$. Com isso, o Clube da Objetiva ficou respaldado pelo órgão brasileiro responsável por reunir, como membro oficial do movimento fotoclubista brasileiro, os demais fotoclubes do país.

A ligação com o movimento fotoclubista já começara nos primórdios do Clube da Ob́jetiva, antes mesmo da filiação à CBFC, pois houve, por integrantes do CO, um esforço de aproximação com outros fotoclubes, para entender a formação estrutural de uma entidade fotoclubista. Ruy Esteves, vice-presidente em exercício, e Rosary Esteves visitaram a Confederação, cuja
15. Os primeiros cursos de fotografia no FCCB aconteceram na década de 1940 . Disponível em: <www.fotoclub. art.br>.

16. Clube da Objetiva, Ata n. 30 (1980, sem referência ao dia).

17. Clube da Objetiva, Ata $n$ 2 , verso da p. 2 (22 de dez. de 1970).

18. Apesar de a CBFC ter sido fundada durante a 1 . Convenção Nacional de Arte Fotográfica, promovida pelo Foto Cine Clube Bandeirante (dez. 1950), seu funcionamento efetivo só se deu a partir da 2. Convenção, realizada em Niterói, na sede da Sociedade Fluminense de Fotografia (9-10 ago. 1958), quando foram aprovados os estatutos e eleita sua primeira diretoria efetiva. Ver Eduardo Salvatore (1988g)

19. Informação extraída do estatuto da CBFC, capítulo II, art. 8., alínea b (1966).

20. Quando pedida a filiação do clube, o integrante José Francisco Braga foi nomeado representante do $\mathrm{CO}$ junto à CBFC.

21. Os secretários Herros Capello e Ernesto Victor Hamelmann comunicam que o Clube da Objetiva e o Foto Clube de Londrina adquiriram nos termos do estatuto a condição de sócio efetivo, tendo direito a voto pela voz de seus representantes. Ver Circular n. 6 da CBFC, Ata da 8. Assembléia Geral Ordinária da entidade ( 24 e 26 maio 1974). 
22. Carta sem data pedindo auxílio ao FCCB sobre produção de estatuto e regimento interno (Acervo do CO)

23. Informações retiradas do Livro de Atas do Clube da Objetiva (Ata n. 9, 27 jan. 71). Nesse Livro, não há registro nem da autoria da logomarca nem de quem ganhou o concurso.

24. Na época, Ana Maria Pacheco era artista plástica e professora de artes da Universidade Católica de Goiás; Cleber Gouvêa, professor da Faculdade de Belas Artes da Universidade Federal de Goiás; Eduardo Simões, arquiteto e aluno do curso de fotografia da Universidade Católica de Goiás; e Marcos da Veiga Jardim, artista gráfico.

25. Aqui não há a preocupação em colocar a discussão entre arte e fotografia de forma aprofundada, deixado para mais adiante. Contudo, vale ressaltar a existência dessa relação, pois faz parte do movimento fotoclubista, e foi agregada também ao Clube da Objetiva.

26. Fotoarte (1974b).

27. Idem, p. 8. Não há informação do sobrenome da autora ou se ela é fotógrafa ou integrante de algum fotoclube.

28. Ibidem. sede "física" funcionava no Foto Cine Clube Bandeirante, em São Paulo22. O objetivo da visita era buscar as bases administrativas para oficializar a criação do clube: material para constituir o estatuto, o regimento interno, etc. e informações sobre formas de avaliação de fotografia e outras.

Após sua elaboração, o Estatuto do Clube da Objetiva foi aprovado em 12 de janeiro de 1971. No artigo 1. o fica claro o tipo de entidade que o fotoclube constitui; e suas alíneas a e b esclarecem os objetivos, estabelecendo, também, a ligação com outros fotoclubes e, consequentemente, ao movimento fotoclubista brasileiro.

Art. 1..- O clube da Objetiva, sociedade civil, sem fins lucrativos, com personalidade jurídica própria, sede nesta capital, fundado em 16 de dezembro de 1970, tem por finalidade proporcionar a seus associados:

Reuniões de caráter sócio-cultural buscando o mais elevado convívio para difusão da arte fotográfica;

Manter relações com sociedades congêneres e entidades públicas ou particulares para meIhor atingir suas finalidades.

Apesar de prever essa ligação com outros fotoclubes, o estatuto do Clube da Objetiva se volta, de início, para reuniões com os próprios membros, a fim de decidir questões de identidade e organização interna do clube.

Dentre essas questões, houve um concurso, em janeiro de 1971, para a confecção da marca do clube, julgado em 27 de janeiro do mesmo ano pela comissão julgadora: Ana Maria Pacheco, Cleber Gouvêa, Eduardo Simões, Marcos da Veiga Jardim e Luiz Mauro Vasconcellos ${ }^{23}$.

Embora os membros desta comissão, exceto Luiz Mauro, não fizessem parte do CO, eram representantes de setores das artes, no estado de Goiás, tanto na área do ensino quanto da prática ${ }^{24}$. Havia, portanto, uma tentativa clara de relacionar a fotografia à arte.

Assim, a ligação fotografia-arte com o fotoclubismo, em Goiânia, além de estrutural, se dá também em nível ideológico, uma vez que há a tentativa de integrar a fotografia ao "mundo das artes". Isso é percebido pela própria história da fotografia e também por ser assunto sempre discutido entre os fotoclubistas, na tentativa de elucidar a questão sobre o que é uma foto artística e, com isso, partir do pressuposto de uma relação quase intrínseca entre arte e fotografia ${ }^{25}$, ao desenvolvê la no interior dos fotoclubes.

Uma das formas de colocar esse posicionamento, na época, era por meio de revistas como a Fotoarte 26 , em que consta o texto "Foto artística" assinado por Marly ${ }^{27}$. Para essa autora a condição primordial para o fotógrafo que pretende ser artista é praticar "certa arte" e ter o domínio de técnica. Segundo ela, a boa foto é aquela que atinge a finalidade desejada. E coloca a questão: "Qual a finalidade da foto artística?", retórica, respondendo que a fotografia artística, como todas as artes plásticas, procura o mesmo fim, ou seja, "a arte é tudo que se cria, que se torna presente, da maneira como se quer" 28 .

Embora essa discussão apareça nas revistas, boletins informativos de outros fotoclubes ou mesmo nas fotografias dos fotoclubistas, nenhum dos artigos 
do Estatuto do Clube da Objetiva contempla tais questões de fundo ideológico, e volta-se para a prática. Algumas atividades 29 a compõem, direcionadas tanto ao público interno quanto ao externo. Internamente, destacam-se o julgamento de fotografias e as excursões; e, externamente, a realização de uma exposição e um concurso (de âmbito internacional) pelo menos uma vez ao ano.

No primeiro ano de atuação do fotoclube de Goiânia, dessas quatro atividades, somente a exposição e o julgamento interno de fotografias parecem ter sido concretizados ${ }^{30}$. Contudo, o julgamento não perdurou por muito tempo, enquanto a organização de exposições tornou-se uma prática constante.

Para o final de cada trimestre, ficou decidida a realização de concursos internos e julgamentos de fotografias, com um tema escolhido pelo grupo. $\mathrm{Na}$ apresentação dessas fotografias, não era necessário ineditismo, sendo que mesmo as já pontuadas poderiam ser reapresentadas.

Em 1972, os temas propostos nos concursos internos foram: Alegria, Tristeza, Chuva; Ação, Baixo; Paisagem, Telhados; Carnaval, Velhos; Marginais, Expressões Fisionômicas; Profissionais, Mãos. A variação temática mantinha aproximações com os tipos de temas tratados em outros fotoclubes, como se pode perceber através da circular mensal do FCCB, de junho de 1973, que apresenta como temas para o concurso interno daquele mês "Expressões humanas e/ou noturno em movimento".

As fotografias apresentadas também passaram a ser avaliadas segundo os critérios do FCCB ${ }^{31}$ - visão, interpretação, composição e técnica -, que constam do modelo de ficha de inscrição do concurso interno, pontuados de 1 a 5 para cada item, sendo anotada a pontuação dada por cada membro do júri e a média obtida, resultando na categoria do classificado ${ }^{32}$. No boletim informativo do Foto Cine Clube Bandeirante de junho de 197333, há explicações sobre os critérios de análise de uma fotografia, especificados a seguir.

"Visão ou Concepção", consistia na avaliação da escolha do assunto, pela originalidade do tema ou da apresentação, ligada à criatividade. Os pontos negativos estavam ligados a banalidade, imitação, confusão e reprodução. "Interpretação e Tratamento" em que se verificava a adequação ou não ao tema, considerando a naturalidade ou artificialidade, a fim de perceber se o fotógrafo tinha um interesse amplo, geral; ou restrito, limitado e de caráter pessoal. Com isso, também era avaliado o tratamento formal, constatando se a foto era simples documentação e se a escolha do processo utilizado fora, ou não, adequada.

No terceiro item avaliava-se a "Composição", cujo objetivo era verificar se a organização dos elementos que formam o quadro estava harmoniosa: formas, linhas, massas, tons, luzes e sombras, ângulo de tomada, perspectiva, utilização do campo focal, corte, enquadramento, equilíbrio, cores (nas fotos ou diapositivos em cores). E, por último, verificava-se a "Técnica de Laboratório", que avaliava a qualidade da cópia ou ampliação, por meio dos aspectos de definição, textura e rendimento tonal, analisando, também, se a execução técnica do processo utilizado havia sido bem ou mal feita, resultando em um bom acabamento e apresentação e, ainda, um bom aproveitamento e rendimento das cores.
29. As atividades exposição, concurso e excursão estão descritas no artigo 25 , respectivamente alíneas $e, f$ e $\boldsymbol{k}$ Já o julgamento interno não consta no estatuto, mas no Livro de Atas (Atas n. 4, 6 jan. 1971, p. 5).

30. Considera-se 1971 o primeiro ano de atuação, pois o clube fora criado em fins de 1970.

31. Houve proposta de mudança dos critérios de avaliação das fotografias, baseando-se no julgamento do FCCB (Ata n. 18, 28 set. 1971).

32. Na ficha está a pontuação e a correspondente categoria. Principiante: 8 a 11; Aspirante: 11 a 13; Júnior: 13 a 15 Sênior: 15 a 18 . Contudo, não há informações se tal pontuação era cumulativa ou reiniciada em cada julgamento.

33. Estas informações estão na página 2 do referido boletim. Cada item ganha uma pontuação - 1: fraca; 2 : sofrível; 3: regular; 4 : boa; 5 : muito boa. 
34. Tais concursos internos não parecem ter tido a freqüência desejada nem perdurado por muito tempo, mas há registro no Livro de Atas, no ano de 1971 , da apresentação de fotografias a partir dos temas: Feira, escolhida Rosary Esteves (p.13), 2. lugar, Décio Marmo de Assis; e 3, Ruy Esteves (Ata n. 12, 6 abr. 1971); Abstrato de Décio Marmo de Assis (Ata n. 14, 10 ago. 1971; Tipos Populares, venceu Rosary Esteves (Ata n. 18, 28 set. 71).

35. Palavras ditas em entrevista à pesquisadora.

36. Cf. Carlos R. Asborno (1987, p. 8).
Percebe-se, com isso, um alinhamento claro do Clube da Objetiva às regras, não só as administrativas, como também as que balizavam a produção fotográfica, caracterizando a instituição como participante do movimento fotoclubista. Fica clara a preocupação desse movimento tanto com a questão artística quanto com a técnica, perceptível pela adequação à avaliação. Embora o fotoclube de Goiânia tenha exposto que, em um primeiro momento, priorizara, na avaliação, os aspectos artísticos, em detrimento da técnica.

Esses critérios, além de serem utilizados no interior dos fotoclubes, serviam de base para a avaliação em salões de fotografia. Logo, os concursos internos acabavam servindo de preparação à participação nesses salões, configurados como concursos externos interclubes de fotografia.

Com essa possibilidade de preparação, os concursos internos adquiriam grande importância, uma vez que proporcionavam o crescimento artístico e técnico dos integrantes e a adequação ao movimento clubístico. Embora se perceba essa importância, o Clube da Objetiva parece ter abandonado a prática em 1972, pois não há registro de outros concursos internos ${ }^{34}$. A razão para a diluição desses concursos talvez seja o atrito gerado entre os integrantes, devido a críticas às fotografias. Sobre isso, Rosary Esteves diz que "mesmo as críticas não sendo explícitas, elas aconteciam"35. As reações às críticas aos julgamentos das fotografias não aconteciam somente no $C O$, mas também em outros fotoclubes, como relata Carlos R. Asborno, membro do FCCB:

Alguns fotógrafos se ofendem, acham que os elementos do Júri não têm qualificação para opinar sobre as obras de arte de um fotógrafo do nível dele; alguns consideram o Júri "acadêmico" demais, outros opinam que é "moderno" demais [...] Outros autores (mais esclarecidos) ouvem atentamente todas as opiniões, analisam os comentários e depois decidem se devem trabalhar em cima das ideias sugeridas ou, talvez, usar as opiniões dos julgadores como ponto de partida para criar em cima delas ${ }^{36}$.

O retorno dos concursos internos parece ter acontecido em 1977, no mês de junho, com os temas Portas e Janelas, ou Livre. A prática voltou a ter continuidade em 1978, contudo com uma mudança na forma de avaliação. Ao invés de a pontuação se dar pelas fotografias apresentadas internamente, passa a ser obtida pelas fotografias selecionadas em salões nacionais e internacionais e concursos fotográficos.

Na Ata n.․ 30, de 12 de julho de 1978, foi feita a descrição da pontuação considerada válida para os concursos internos do clube, conforme a participação em salões de fotografia: fotografia aceita em Salão Nacional (2 pontos); fotografia aceita em Salão Internacional (4 pontos); menção honrosa em Salão Nacional (6 pontos); menção honrosa em Salão Internacional (12 pontos); 3. lugar em Salão Nacional (12 pontos); 3. lugar em Salão Internacional (24 pontos); 2. lugar em Salão Nacional ( 15 pontos); 2. lugar em Salão Internacional (30 pontos); 1. lugar em Salão Nacional (30 pontos); 1.. lugar em Salão Internacional (60 pontos). Para os resultados obtidos em salões e concursos regionais, era considerado apenas 1 ponto. No final de cada ano, o resultado geral tornava-se conhecido, com os nomes dos 
vencedores. Mas era feito um balanço, de vez em quando, acumulando-se os resultados de um mês para o outro.

A mudança do método de pontuação foi decorrente de uma nova forma de análise, que sai do escopo do fotoclube local e vai para o âmbito nacional ou internacional, na medida em que os fotoclubistas não mais criticavam as fotos uns dos outros. Em contrapartida, aceitavam as críticas dos fotoclubes nacionais e internacionais, o que pode ter gerado uma diminuição das discussões internas acerca das fotografias. Ao mesmo tempo, pode ter estabelecido um ambiente mais agradável entre os participantes, uma vez que, muitas vezes, as críticas geravam certo desconforto entre os integrantes.

Apesar de ter havido essa mudança formal no método de avaliação do concurso interno, o seu objetivo foi mantido, ou seja, criticar a produção fotográfica de cada membro do clube, a partir dos itens visão, interpretação, composição e técnica de laboratório. Os membros do Clube da Objetiva, contudo, eximiam-se disso, evitando atritos posteriores, uma vez que, de uma maneira sutil, tal tarefa foi passada aos membros de outros fotoclubes. Dentro do $\mathrm{CO}$, os integrantes passam a ser apenas produtores, eximindo-se do papel de críticos das fotografias dos colegas.

Como, naquele momento, a pontuação se dava pela aceitação das fotografias nos salões, essas passavam por críticas, recebidas pelos integrantes através da seleção ou não de sua fotografia. Com isso, o que se dava internamente, de fato, não era mais a avaliação, mas somente a contagem dos pontos.

A mudança administrativa do concurso não criou um distanciamento com os critérios do movimento fotoclubista, e gerou, ao contrário, maior aproximação, na medida em que impulsionava os integrantes do $\mathrm{CO}$ a participarem de salões e concursos organizados por outros fotoclubes. Com isso, o fotoclube de Goiânia perde no desenvolvimento de características visuais locais, mas ganha no alinhamento à visualidade do fotoclubismo em nível global.

Também no sentido de impulsionar a produção fotográfica do Clube da Objetiva, organizaram-se, desde seu início, além dos concursos internos, também exposições fotográficas. De acordo com relatos do Livro de Atas, a primeira exposição do clube ficou marcada para 15 de fevereiro de $1971^{37}$. Porém, no Livro de Visitas dessa exposição (com 1260 assinaturas), a data de abertura foi 28 de fevereiro de 1971 e o fechamento em 7 de março do mesmo ano, no edifício sede da Caixa Econômica do Estado de Goiás - Caixego ${ }^{38}$.

Com essa primeira Exposição do Clube da Objetiva há o contato inicial com o público externo, constituindo-se no primeiro passo efetivo para a divulgação da instituição. As primeiras respostas começaram a vir, através de comentários (escritos no Livro de Visitas) de visitantes sobre as fotografias $A$ madona e o menino, Luz e sombra, Os carvoeiros, Condenado ao inferno, Ninguém está me vendo, Tocador de melância, Labuta diária, Reflexo e Pesquisa 1, mostrando, assim sinais de aprovação e aceitação do público às fotografias aí apresentadas.

Além da exposição, outra atividade de grande importância foi a realização de três palestras, dadas por integrantes do Clube, Elder Rocha Lima,
37. Ver Ata (n. 6, 19 de jan. 1971).

38. A Caixego era a caixa econômica do estado de Goiás, fechada em 1990. 
39. Os salões de fotografia promovidos pelo $\mathrm{CO}$ são abordados mais adiante; agora só são citados para melhor compreender o encadeamento histórico do clube.

40. A posse da nova diretoria deu-se em 5 jul. 1976. A presidente escolhida foi Lurdinha Pacheco.

41. Não há informações sobre o tempo de duração desta Fundação e se realmente teve um trabalho efetivo.
Rosary Esteves e Amaury Menezes, cujos temas foram respectivamente A fotografia como artes plásticas, Papel fotográfico e Composição. Entretanto tal atividade parece ter sido esporádica, tanto que não consta no Estatuto como prática permanente do clube.

No ano de 1972, o CO seguiu com a promoção anual de uma exposição de fotografias e conseguiu cumprir a realização de um salão de fotografia ${ }^{39}$. Apesar de ainda não ser anual, organizou o 1. Salão de Arte Fotográfica de Goiás, de nível estadual, juntamente com a Prefeitura de Goiânia. Com isso conseguiu a propagação de seu nome e de sua produção fotográfica a todo estado de Goiás, além de uma aproximação com o poder público.

Com isso, nota-se certa flexibilidade em relação ao cumprimento do Estatuto. O próprio documento, contudo, prevê sua mudança, conforme artigo 16.․ alínea f: "Modificar o presente estatuto" - as alterações poderiam ser aprovadas em Assembleia Geral. Em contrapartida, mudavam-se as práticas (as atividades e o funcionamento do CO), e a teoria (regras contidas no estatuto) permanecia a mesma.

Do fim de 1971 até 1976, essa flexibilização chegou ao extremo, uma vez que as reuniões do clube estiveram suspensas no período. Entretanto, o Clube da Objetiva não fora extinto, pois os integrantes continuaram se encontrando e participando de salões, prevalecendo neste momento o contato com os outros fotoclubes.

Em 1976, Ruy Esteves, o então presidente, sugeriu a reestruturação do clube e anistia das anvidades vencidas, além de convocar assembleia ordinária para eleições. A nova eleição ${ }^{40}$, aconteceu em 28 de junho de 1976, de acordo

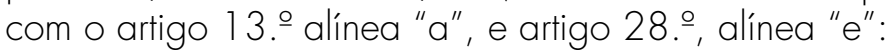

Art. 13.- - A Assembleia Geral reunir-se-á:

a) Ordinariamente de dois em dois anos para eleição de Diretoria, na segunda quinzena de março;

Art. 28.. - Compete ao Presidente:

e) Convocar as reuniões da Diretoria, do Conselho Deliberativo e as Assembleias Gerais Ordinárias;

Apesar da nova diretoria, o direcionamento do clube continuou norteado pelas mesmas atividades: exposições, saídas fotográficas e promoção de salões. A novidade foi que o $\mathrm{CO}$ conseguiu realizar os salões nacionais, que aconteceram nos anos de 1977, 1978, 1980, 1981 e 1987. Com a promoção desses salões, o clube consegue atingir dois públicos que estavam sendo tratados separadamente. Assim, o CO estabeleceu contato direto com a sociedade goiana e também com a "comunidade" fotoclubista, e começa a ter a sua legitimidade institucional tanto em nível local quanto em nível nacional, tornando-se, portanto, parte da cultura de Goiânia e dos fotoclubes brasileiros.

Em nível local, essa legitimação foi promovida não só pela sociedade como também pelas autoridades da cultura no Estado de Goiás. Percebe-se isso pela inserção do Clube da Objetiva na programação da Fundação Cultural de Goiás, entidade do Governo do Estado ${ }^{41}$, criada em 1979, cuja finalidade era 
promover, incentivar e amparar a prática, o desenvolvimento e a difusão das atividades culturais em Goiás.

A Fundação convidou o CO para mensalmente fazer parte de sua programação cultural, a fim de ser incluído no "Boletim-calendário", distribuído às entidades culturais do estado ${ }^{42}$.

Devido à realização de várias atividades culturais, ao reconhecimento do público e do estado e pelo fato de o Clube da Objetiva ser uma instituição sem fins lucrativos, foi sugerida (em 1980, em reunião ${ }^{43}$ ) a possibilidade de tornar-se de Utilidade Pública o Clube. Segundo Helouise Costa e Renato Rodrigues da Silva, no fotoclubismo em âmbito nacional, esse título começou a ser outorgado aos fotoclubes em meados dos anos 1950, período que os autores consideram o de maior desenvolvimento "tanto do ponto de vista artístico quanto social" do movimento. E completam: "Alguns clubes passaram a ser considerados entidades de utilidade pública, título outorgado pelas Assembleias Legislativas locais pelos serviços prestados à comunidade" 44 .

Mesmo nas décadas de 1970 e 1980, esta prática continuou. Embora - Clube da Objetiva tenha aventado a possibilidade desse reconhecimento, como disse Lurdinha Pacheco ${ }^{45}$, a ideia não foi levada adiante, o que impossibilitou a aquisição do título. Entretanto, isso não invalida a divulgação da fotografia, promovida pelo CO na sociedade goiana, e a inserção efetiva do CO e de Goiânia no movimento fotoclubista.

Para isso, outra atividade que aproxima o Clube da Objetiva dos demais fotoclubes é a confecção de boletins informativos, prática bastante comum no ambiente fotoclubista. Em 1980, a diretoria presidida por Lurdinha Pacheco adotou a publicação de boletins informativos mensais ${ }^{46}$, que tinham como finalidade divulgar o clube e informar os associados e pessoas interessadas em fotografia. Entretanto, a periodicidade dos boletins durou apenas dois meses e não se sabe se foram entregues aos demais fotoclubes, o que diferenciaria o Boletim do CO na prática de intercâmbio de boletins entre os clubes.

Pelos seu conteúdo, os boletins tiveram a preocupação de veicular notícias das atividades internas do clube, referentes às decisões de reuniões e datas de acontecimentos, como exposições. Em nenhum momento foram utilizados como espaço para discussão da estética fotográfica ou da relação entre arte e fotografia desenvolvida no interior do fotoclubismo, como se fez em outros fotoclubes, a exemplo do Foto Cine Clube Bandeirante (SP), da Associação Brasileira de Arte Fotográfica (RJ) ou mesmo da Confederação Brasileira de Fotografia e Cinema (SP) ${ }^{47}$.

Como não se sabe se os boletins informativos foram veiculados fora do clube, não se pode afirmar se serviram como mais uma "ferramenta" de aproximação do clube e da fotografia com a sociedade goiana e os demais fotoclubes. É patente, porém, a divulgação do fotoclube e da fotografia através dos salões e exposições, atividades que melhor mostravam a "cara" do Clube da Objetiva.

Assim, em 25 de setembro de 1987 o CO recebeu o prêmio Tiokô48, na área de fotografia, pela União Brasileira de Escritores, Seção Goiás, no Museu
42. Embora tal carta-convite exista, não foram encontrados indícios (calendários, por exemplo) da participação do CO nessa Fundação.

43. Ver Ata (n. 31, 8 set. 1980).

44. Cf. Helouise Costa e Renato Rodrigues da Silva (2004, p. 48).

45. Em Entrevista à pesquisadora (out. de 2006).

46. Só há registro da publicação de dois boletins informativos do $\mathrm{CO}$, ambos nessa diretoria. E não se sabe se foram distribuídos para outros fotoclubes e entidades ou se foram utilizados só internamente.

47. Os conteúdos dos boletins informativos destes fotoclubes serão melhor abordados mais adiante.

48. Prêmio máximo da cultura em Goiás. Ver Brasigóis Felício (1987). Ganharam também este prêmio: Maria Helena Chein (literatura); Gomes de Sousa (artes plásticas); ex-prefeito de Goiânia Venerando de Freitas Borges (especial); Martiniano J. Silva (história); Antônio Poteiro, Iza Costa, Betúlia Machado e Flávio Köthe (homenagens especiais) 
49. Cf. Roland Barthes (1984, p. 57)
Pedro Ludovico. Com a premiação, o fotoclube de Goiânia recebe a oficialização da sua legitimidade enquanto instituição fotográfica presente na cultura da cidade de Goiânia e firma-se como instituição promotora da cultura no estado de Goiás.

Salões de Arte Fotográfica

Fotografias $30 \mathrm{~cm} \times 40 \mathrm{~cm}, \mathrm{P} \& \mathrm{~B}$ ou coloridas, expostas uma do lado da outra em paredes ou painéis. Em geral, era essa a configuração dos salões de arte fotográfica promovidos por fotoclubes de nível estadual, nacional ou internacional. Esses salões tinham como objetivo principal a divulgação da fotografia como arte, desenvolvida no interior dos fotoclubes, tanto para o público em geral quanto para os fotoclubistas. Com isso, era gerado um intercâmbio entre clubistas e clubes. Nesse sentido, pode-se dizer que havia uma tentativa de uniformização da prática fotográfica.

Apesar de ser aberta a qualquer fotógrafo a inscrição de fotografias a serem julgadas para um salão de fotografias promovido por algum fotoclube brasileiro, o regulamento era remetido aos fotoclubes, ou divulgado através dos boletins informativos, e não, pelas mídias convencionais, o que acarretava uma maior participação dos fotoclubistas em detrimento de pessoas vindas de fora.

Como os participantes dos salões compartilhavam de um mesmo princípio fotográfico, no que tange à técnica e à visão artística, não havia grandes mudanças de estilo de um salão para outro. Para Roland Barthes,

a foto se torna "surpreendente" a partir do momento em que não se sabe por que ela foi tirada; qual motivo e qual interesse para fotografar um nu, contra-luz, no vão de uma porta, a frente de um velho automóvel na grama, um cargueiro no cais, dois bancos em uma pradaria, nádegas de mulher diante de uma janela rústica, um ovo sobre uma barriga nua lfotos premiadas em um concurso de amadores ${ }^{49}$.

Por considerar a ausência de novidade, de imagens capazes de surpreender o espectador, o autor não vê surpresa nas fotografias de salões fotoclubistas. Barthes defende que a surpresa da fotografia está em ser tirada sem um objetivo específico, o que já invalidaria as fotografias de salão, uma vez que são pensadas para ser aceitas aí.

Em contrapartida, na visão do fotoclubismo, as fotografias de salões podem surpreender, desde que o fotógrafo não se prenda às normas ou ao que o julgador vai pensar de sua fotografia. Apesar do fotoclubista Eduardo Salvatore ver tal possibilidade da novidade nas fotografias dos clubistas, em dezembro de 1987, no boletim informativo do FCCB, ele escreve a respeito da estagnação fotográfica percebida nos salões de fotografia:

Pouca criatividade, pouca originalidade, muita repetição de temas já bastante explorados, bastante vistos e, o que é pior, tratados sempre da mesma maneira [...] Trabalhos comuns, 
portanto, que nada de novo nos trazem. [...] Isto reflete a busca somente pela conquista de títulos para figurar estatísticas como a PSA ou a FIAP, o que se denomina de "Salonismo", o que pode dar uma satisfação pessoal ao "salonista", mas não leva a nada em termos de evolução (mesmo pessoal) e não acrescenta nada à arte fotográfica ${ }^{50}$.

Percebe-se, então, que a busca pela aceitação nos salões acabava gerando a mesmice fotográfica, impedindo a agregação de novos valores à fotografia artística. Ainda conforme Salvatore, "o que se deve procurar é uma visão e interpretação pessoal, original e criativa dos mesmos. Não a simples cópia de algum trabalho que alcançou sucesso" ${ }^{\prime 51}$.

Esta mesmice conferida às fotografias dos salões fotoclubistas também foi alvo de críticas em um jornal de Goiânia ${ }^{52}$, na ocasião da realização do 3. Salão promovido pelo Clube da Objetiva. $\bigcirc$ então presidente Odessa Hermano critica, em matéria do Top News, as críticas desse jornal por elas afirmarem que o salão não apresentava nada de diferente:

Perguntamos: existe alguma coisa de diferente em fotografia? A fotografia pelo que sabemos continua sendo apenas um registro do cotidiano, algumas com o uso de técnicas e outras, simples, sem tratamento especial. Além da variação do tratamento e da diversificação dos temas abordados, não há o que se falar em "novidade" ou em "diferença". Fotografia é só isto aí mesmo. Os trabalhos apresentados neste III. Salão são considerados os melhores que se têm feito atualmente, em termos de fotografia, no Brasil|53.

Como se percebe, os fotoclubistas não aceitavam muito tranquilamente a "acusação" de repetição fotográfica. Em contrapartida, os próprios catálogos veiculados nos salões, contendo as fotografias aí premiadas ou aceitas, serviam para nortear o que os júris desses salões acreditavam ser fotografias artísticas. Apesar de haver tal norte, não se pode dizer que existia uma corrente fotográfica única. Várias estéticas "conviviam" no mesmo espaço. Assim como expõem Helouise Costa e Renato Rodrigues da Silva:

Havia assumidamente um gosto pela convivência entre as várias concepções da estética fotográfica, o que só foi possível devido a duas razões: primeiro pela inexistência de um corpo teórico suficientemente estruturado que desse conta das consequências estéticas últimas de uma especulação moderna; segundo devido à defesa de uma ideologia liberal bem ao gosto da pequena burguesia urbana ${ }^{54}$.

Por isso, os organizadores dos salões colocavam nos júris fotoclubistas com visões diferenciadas, sendo, assim, comum que pessoas de outros fotoclubes fossem convidadas para compor o júri ${ }^{55}$ dos salões, a fim de garantir o ecletismo, além de aumentar o intercâmbio.

Buscando um relacionamento efetivo com os demais fotoclubes e, consequentemente, a adequação ao movimento fotoclubista, era usual que os fotoclubes participassem dos salões, levando a uma legitimação dos mesmos. Contudo, além da participação, muitos dos fotoclubes recém-criados, em contato com os mais antigos, que os auxiliavam, organizavam seus próprios salões. Em
50. Ver Eduardo Salvatore (1987), no texto é Considerações à margem do 39. Salão de Fotografias, referente ao 39o Salão Internacional de Arte Fotográfica promovido pelo FCCB

51. Idem, p. 5

52. Não há referência ao nome do jornal, apenas foi mencionado por Odessa Hermano em resposta à crítica; Cf. Odessa Hermano (1980).

53. Ibidem.

54. Helouise Costa e Renato Rodrigues da Silva (2004, p. 58)

55. Como se vê na composição do Júri do 1 . Salão Nacional de Arte Fotográfica do Clube da Objetiva, em 1977. 
56. Vicente João Pedro foi membro da comissão julgadora do 1. Salão. Na época fazia parte da Confederação Brasileira de Fotografia e Cinema e era presidente do Fotoclube de Jaú (SP).

57. Ver Vicente João Pedro (1977).

58. O prefeito de Goiânia na época era Manoel dos Reis e Silva.

59. Ver Clube da Objetiva (1972).

60. Os integrantes da comissão foram: Ruy Esteves Pereira, Hardy Silva, Luiz Mauro de Vasconcelos e Rosary Caldas Esteves Pereira.

61. Foram premiados: César Silva (Medalha de ouro); Marilda B. Assis (Medalha de prata); Décio Marmo de Assis (Medalha de prata); Marilda B. Assis (Medalha de bronze); Doracy Lemes (Medalha de bronze); Alois Feichtenberg (Medalha de bronze); Décio Marmo de Assis (Menção honrosa); Hélio Nunes de Oliveira (Menção Honrosa). Para as fotografias de Goiânia, por decisão do júri, não foi dado prêmio especial. consonância com este percurso, o fotoclube de Goiânia, ao longo das décadas de 1970 e 1980, promove os seus salões de fotografia.

Com a promoção desses salões, o Clube da Objetiva consegue a sua legitimação definitiva no ambiente fotoclubista, como fala Vicente João Pedro ${ }^{56}$ ao jornal O Popular, sobre o 1. Salão Nacional de Arte Fotográfica: "é um trabalho que deixa o Clube da Objetiva daqui em igualdade de condições com qualquer outro do país, e que o coloca entre os primeiros lugares em atividades fotográficas". ${ }^{57}$ Logo, os salões de fotografias, por constituírem espaços de trocas de fotografias e de intercâmbio entre fotoclubes, assumem uma importância fundamental no desenvolvimento do movimento fotoclubista brasileiro.

\section{Salão Estadual de Arte Fotográfica}

Antes da realização de um salão de fotografia em nível nacional, foi feito um estadual - 1.. Salão de Arte Fotográfica de Goiás -, em outubro de 1972, em estande na praça do Bandeirante. O evento estava ligado ao Encontro de Goiânia, como parte das comemorações do 39. Aniversário de Goiânia, de 20 a 31 de outubro.

Apesar de ter sido um salão de fotografias, o primeiro do $\mathrm{CO}$, ele não apresenta características típicas do fotoclubismo, uma vez que se restringia à participação de fotógrafos goianos. Por isso, seu apelo foi muito maior no ambiente cultural da cidade do que no movimento fotoclubista.

Além disso, o clube fora convidado a organizá-lo, pela prefeitura de Goiânia ${ }^{58}$, não sendo, portanto, uma ideia nele surgida. Havia, ainda, a preocupação em fazer menção à cidade de Goiânia, até por ser realizado em comemoração ao seu aniversário, o que justifica uma premiação especial à melhor fotografia da cidade, prêmio que, afinal, acabou não sendo concedido, com a justificativa da comissão julgadora de que "nenhum trabalho se mostrou realizado o bastante para merecê-lo" 59 .

Apesar de um distanciamento da prática fotoclubista, devido à ausência de intercâmbio com outros fotoclubes, a aproximação se dá pelo fato de formar-se a comissão organizadora com integrantes do $\mathrm{CO}^{60}$, que participaram da exposição, mas não da premiação. Os organizadores escolheram a comissão julgadora, formada por Adelmo de Moura Silva Café, José Amaury de Menezes, Marcos Henrique da Veiga Jardim, Moacir Laterza e Sílvio Berto, pessoas ligadas ao cenário artístico de Goiás, criando uma ligação da fotografia com a arte, mas não estritamente ligada ao fotoclubismo.

Entretanto, a maioria dos premiados era de integrantes do Clube da Objetiva, exceto Alois Feichtenberg, Doracy Lemes e Hélio Nunes de Oliveira. Apesar de a comissão organizadora ser composta por membros do clube, não houve restrição para a participação com concorrência de fotografias ${ }^{61}$.

Embora não tenha havido uma relação direta com o movimento fotoclubista, uma vez que os outros fotoclubes não participaram, ideologicamente 
o salão estava ligado ao CO. Com isso, constituiu-se a porta de entrada para instaurar a promoção de salões em nível nacional.

Salões Nacionais de Arte Fotográfica

O desejo de promover um salão nacional vinha desde 1973, um ano após a realização do salão estadual, contudo, a solicitação de patrocínio ao então prefeito de Goiânia foi indeferida. Somado a isso, o clube não se reuniu com frequência, de 1973 a 1976, o que contribuiu para a impossibilidade de realização do salão nacional no período.

Apesar dessa primeira tentativa frustrada, de 24 de setembro a 15 de outubro de 1977 acontece o 1ํ. Salão Nacional, no Parthenon Center. Os salões seguintes, do segundo ao quinto, aconteceram, respectivamente, em novembro de 1978, no Palácio da Cultura; em março de 1980, no Teatro Goiânia; em junho de 1981, no Palácio da Cultura; e em setembro-outubro de 1987, no Shopping Flamboyant.

Percebe-se que não houve regularidade nos intervalos de ocorrência dos salões, o que pode estar relacionado a questões de ordem econômica. Ainda em relação ao período, não há uma data fixa para a realização das exposições, uma vez que cada salão ocorreu em mês diverso (só houve coincidência nos meses do 1으 e do 5의.

É possível que a tentativa do clube fosse de que o salão se repetisse anualmente, mas, como acabou não acontecendo, o CO talvez tenha optado por não criar expectativas na sociedade em relação ao seu acontecimento, havendo sua descaracterização como marco cultural, por não ter data e local pré-estabelecidos.

A falta de regularidade, contudo, não invalidou a acolhida pelo público, percebida através do número de visitantes. $\bigcirc$ livro de visitas do 1. Salão teve mais de 1.500 assinaturas e, vale ressaltar, foi encerrado 10 dias antes do previsto, devido ao roubo de seis fotografias ${ }^{62}$. Cerca de 750 visitantes registraram presença no 2. Salão; e, no terceiro, cerca de mil. Por inexistirem seus livros de visitas no acervo do $\mathrm{CO}$, não é possível dizer quantas pessoas visitaram o $4 .{ }^{\circ} \mathrm{e}$

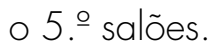

A falta de permanência relativa às datas dos salões, também se estende ao local, uma vez que eles não se repetem (exceto no $2 .{ }^{\circ}$ e no 4. ․ . Contudo, os locais estão ligados aos governos municipal e estadual, o que demonstra dependência ao poder público para a realização do evento. Somente o 5. Salão aconteceu em um centro comercial de caráter privado - mas isso não invalidou o apoio do governo, através da Secretaria Estadual de Cultura, informação que consta nos agradecimentos.

Quanto à divisão das categorias, 01. Salão apresenta apenas duas - Monocromáticas e Diapositivos -, que representam a divisão usual de qualquer salão. Mesmo havendo filme colorido, ainda não era de praxe utilizá-lo na prática
62. Ver Rachel Azeredo (1977). O salão teve de ser encerrado 10 dias antes do previsto, devido ao furto de 6 fotografias. Dentre elas estava Branca de neve, de Délcio Capistrano (1. lugar), e outras de nus femininos. No dia 30 houve o primeiro furto: Dois detalbes, de Wanda Werneck (Socidade Fotográfica de Nova Friburgo) Depois, entre os dias 2 e 3 , a citada Branca de Neve, de Délcio Capistrano (Associação Carioca de Fotografia). Também faziam parte do lote: Contraluz, de Paulo Vital (Academia Santista de Fotografia); Cláudia, de Antônio Carlos de Sousa (Socidade Fotográfica de Nova Friburgo); e Pensativa, de Ângelo Portela Neto (Fotoclube de Londrina); e mais uma, não identificada. 
63. Este júri popular foi formado por um funcionário público, uma dona de casa, uma chacareiro, um enfermeiro e um jovem estudante de nível médio, respectivamente, Almiro Moreira da Silva, Ana Maria Faria Marçal, José Wagner Cunha Barbosa, Manoel Lourenço Vivas e Rogério Álvares Faria Pereira.

64. Trechos tirados do texto de apresentação do catálogo assinado por Odessa Arruda Hermano, então presidente do CO. fotoclubista, pois, em geral, o próprio fotógrafo manipulava seus filmes, mais comumente $\mathrm{P} \& \mathrm{~B}$, também imbuído de uma dimensão artística que o filme colorido não tinha. No 3. Salão há a inserção da categoria Cópias Cor, refletindo o inevitável aumento do uso do filme colorido, notado também pela quantidade de fotos expostas nesta categoria. Isso porque, tanto no $3 .$. quanto no $4 . .^{\circ}$ Salão o número de fotografias $\mathrm{P} \& \mathrm{~B}$ supera o de coloridas, ocorrendo o inverso no 5. Salão, que aponta para a continuidade desse processo, reflexo do mercado fotográfico.

Apesar de haver essa mudança na relação de quantidade de fotografias nas referidas categorias, até o último salão, a escolha das fotografias impressas nos catálogos dos salões tende a privilegiar as Monocromáticas, em detrimento das Cópias Cor, o que reforça a necessidade de dar esse caráter artístico à produção fotoclubista. Entretanto, a escolha pode muito bem significar a restrição orçamentária do CO para a publicação.

Em relação aos membros da diretoria do $\mathrm{CO}$, percebe-se que, de um ano para o outro, não há diferenças gritantes entre os participantes dos salões, pois, entre o 1.e o 4. ․ (1977-1981), não há um intervalo significativo. Entretanto, em relação ao 5. (1987), já se identifica mudança nos componentes nesse intervalo de tempo, persistindo apenas dois.

Sobre a comissão julgadora, vê-se que o $1 .$. e $\circ 2 .$. salões agregam pessoas não pertencentes ao Clube da Objetiva, o que pode garantir a soma de outros valores à exposição. No 1. Salão, há a presença de dois convidados, também fotoclubistas - logo, esses "outros" valores podem ser estabelecidos no momento da escolha das fotografias, apesar de poder haver grande concordância em relação aos membros do clube, pois compartilham de critérios semelhantes de seleção e de valores estéticos e técnicos.

Já o 2.․․ Salão, a princípio, parece ser mais ousado, pois há a presença de um júri popular ${ }^{63}$, o que pode agregar valores diferentes dos tratados no ambiente fotoclubista. Em contrapartida esse júri não participou da seleção das fotografias inscritas, escolhendo apenas quatro dentre as já selecionadas, da categoria Monocromáticas.

A intenção do júri do CO era dar o 1. lugar a uma fotografia "normal", ou seja, uma que por si só transmitisse uma mensagem, sem o emprego de recursos técnicos, pois "seria a valorização de um trabalho comum, mais próximo da arte popular" 64 . Mas não houve tal fotografia. $\bigcirc$ júri acreditou que isso ocorreu porque a tendência dos salões é premiar fotos com técnicas intricadas; e os autores só enviaram fotos desse tipo. Vê-se que, mais do que a criatividade, o acabamento técnico é valorizado, até pelo efeito visual que causa, o que levou o júri a escolher para $\circ 1$. - lugar uma foło com técnica. Fato que se deu também na escolha dos slides. $\bigcirc$ que é interessante notar é a novidade do júri popular, que mostrou o distanciamento entre a escolha do leigo e a do júri especializado, como se pode perceber pelas fotografias escolhidas para o $1 .$. lugar (Figuras 1 e 2).

Pelas fotografias, pode-se perceber o afastamento nos aspectos da técnica. Enquanto a primeira utiliza a manipulação no laboratório, a segunda usa a fotografia direta, sem intervenções. Além da diferença na escolha do 1.. lugar, 


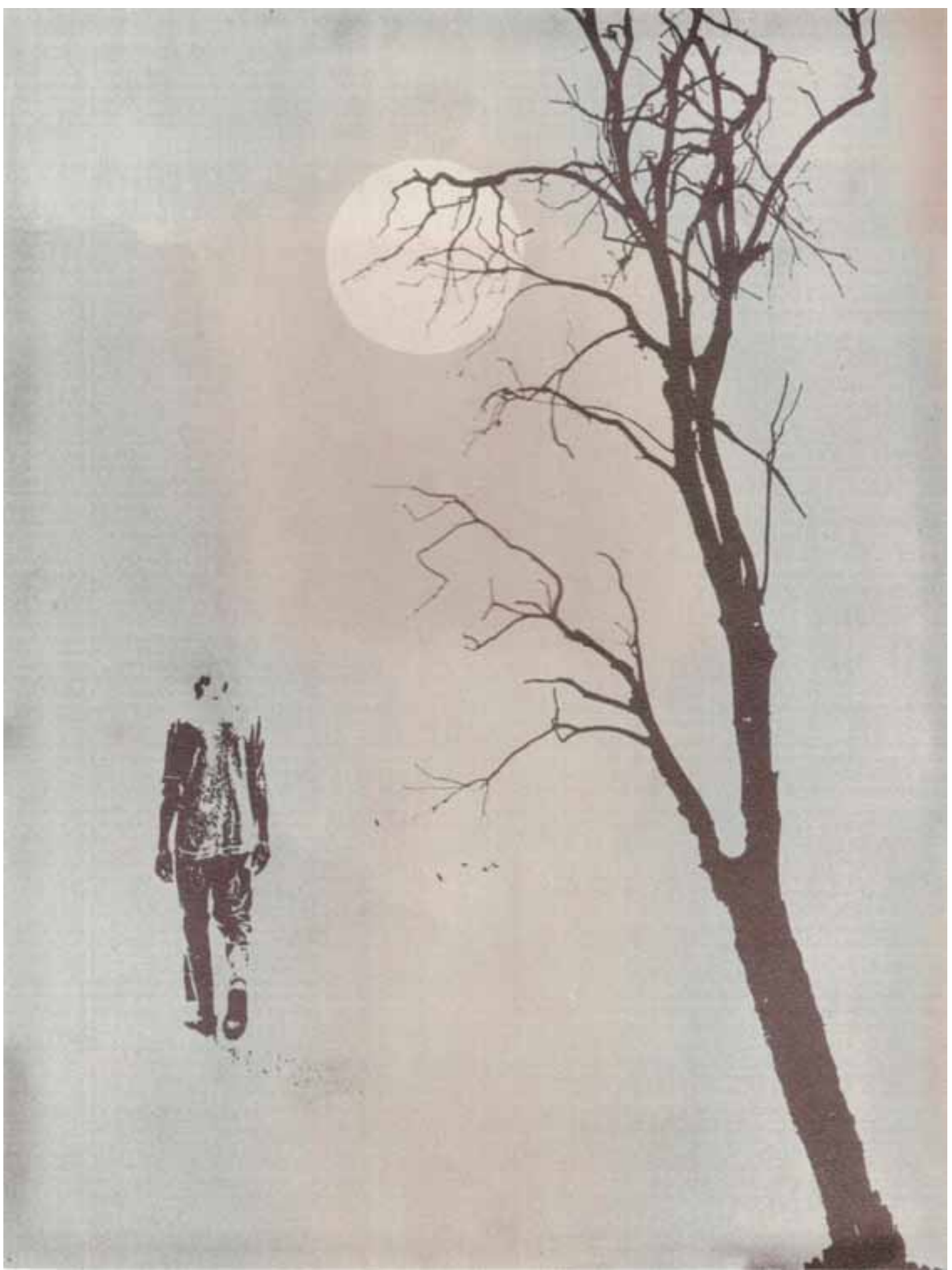

Figura 1 - 1. lugar - Júri fotoclube, "Sem título" - Amílcar Carelli (IFG) - 1978. Catálogo do 2. Salão Nacional de Arte Fotográfica. Acervo do Clube da Objetiva (CO), Goiânia. 


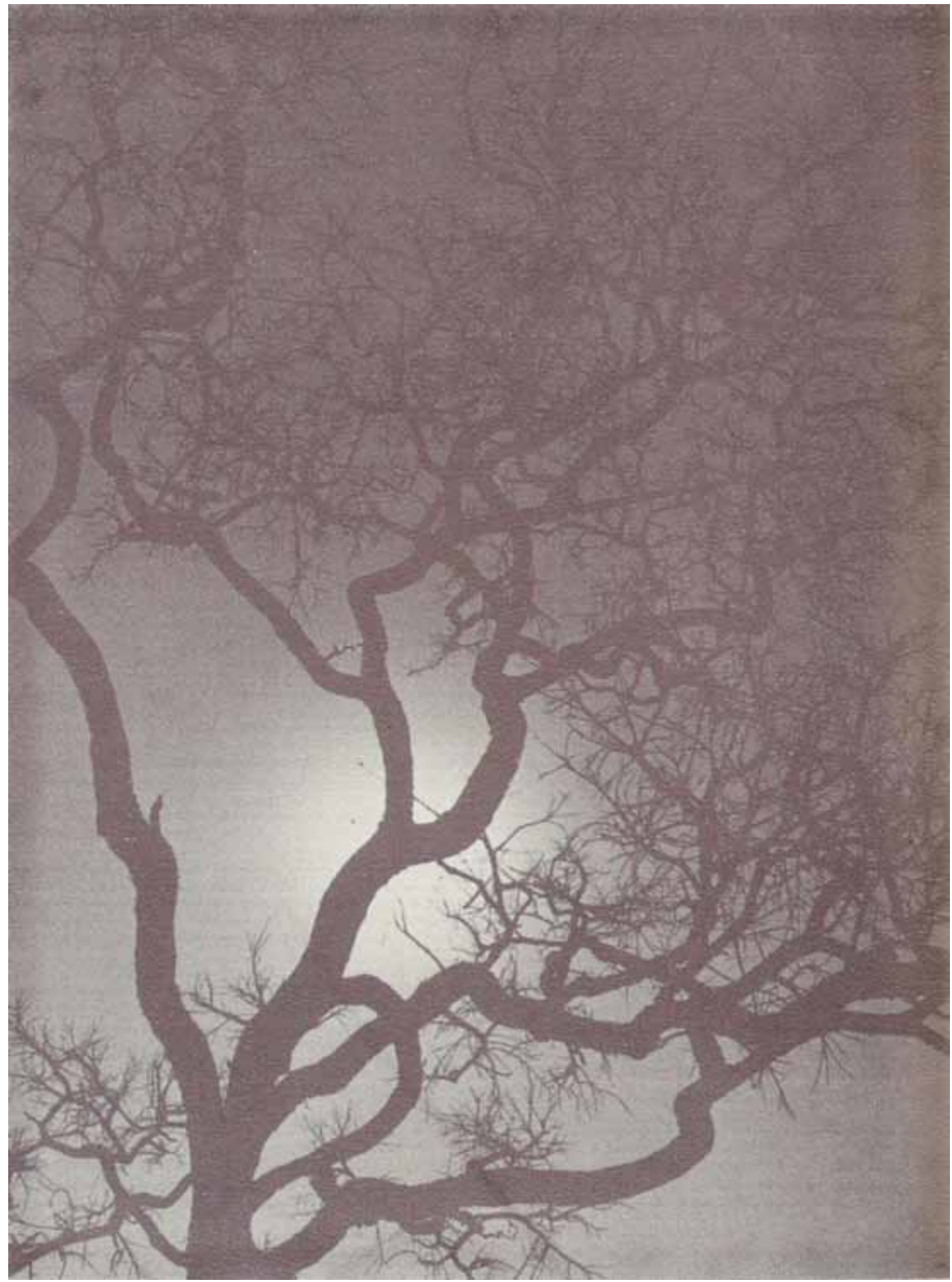

Figura 2 -1. lugar - Júri Popular"Sonata" - Sylvio Moraes (SFF) - 1978. Catálogo do 2. Salão Nacional de Arte Fotográfica. Acervo do Clube da Objetiva (CO), Goiânia. 
não houve nas outras colocações nenhuma fotografia selecionada pelas duas instâncias julgadoras. Assim, não parece que as pessoas "comuns" realmente tenham interferido ou de fato decidido sobre as fotografias da exposição. Entretanto, verifica-se o afastamento criado pelo movimento em relação ao público, na medida em que segue uma forma muito particular de analisar e conceber a fotografia.

Além das fotografias premiadas e aceitas, foram expostas também fotografias dos membros do $\mathrm{CO}$, fora de seleção ${ }^{65}$ (mostra paralela, que não ocorre no 3. e no 5. Salão), constituindo um marco importante, pois há a divulgação do trabalho fotográfico local, que coaduna com o dos outros expositores, dando aos fotoclubistas do CO uma dimensão de qualidade em nível nacional aos olhos do público goianiense.

Quanto à técnica fotográfica predominante, pode-se dizer que também é a fotografia direta, mas tal avaliação provém apenas do 2. Salão, cujo catálogo contém imagens de somente nove fotografias, sendo que, delas, uma única usa técnica de manipulação, a fotomontagem. Assim, não é possível afirmar com certeza, mas aponta para isso.

Essa técnica da fotografia direta, percebida nas fotografias, também é reforçada no texto de apresentação do 2.․ Salão, escrito por Odessa Martins Arruda Hermano, onde são explicitados alguns critérios pautados pela comissão para a escolha das fotografias. Já os textos de apresentação dos outros três salões expõem a importância da realização de um salão de fotografia e sua relação com a cultura.

Nesse sentido, Lurdinha Pacheco, no catálogo do 4. Salão, afirma: "Este quarto salão tem o objetivo maior de deixar patente a disposição da diretoria do Clube da Objetiva de levar a todos a fotografia como atividade útil, necessária e estética, de grande valor documental, e não como um simples hobby dispendioso de uns poucos que somente buscam o inédito, para brilhos individuais" 60 .

No 4. salão, fica claro o desejo do clube de se aproximar da sociedade goianiense através da exposição. E, para isso, critica algumas práticas do fotoclubismo que, por vezes, dão-the a conotação de "gueto", na medida em que sua produção fotográfica é bastante distante do senso comum, como foi mostrado no 2. Salão, com as diferenças de escolha do júri popular e do júri fotoclubista.

Por último, em relação à participação dos fotoclubes, nota-se que ela é superior à dos "avulsos", o que revela o caráter de associativismo do fotoclube de Goiânia em relação aos demais, previsto na própria concepção do fotoclubismo. Além disso, não há grande rotatividade, pois inexistem grandes variações de fotoclubes participantes de um salão para o outro, mesmo no que diz respeito à quantidade.

A atuação do Foto Clube de Londrina é notória, em termos de quantidade de fotografias inscritas, talvez por isso mesmo tenha sido o mais escolhido na maioria dos salões. O Foto Cine Clube Bandeirante, de São Paulo, pioneiro nas experimentações construtivas e fundador de uma estética moderna, também foi bastante atuante, exceto no 1. Salão.
65. Somente no catálogo do 2. Salão Nacional de Arte Fotográfica há fotografias dos membros do CO.

66. Ver Clube da Objetiva (1981). 
67. Faz-se empréstimo deste conceito etnográfico como proposto por Norman K. Denzin (1997).

68. Cf. Idem, p. 54.

69. Cf. Walter Benjamin, (1994, p. 92).
Além dos salões nacionais, sem tema definido, foram realizados dois salões cujos temas foram ecologia e autorretrato. Assim, salões estaduais e nacionais, com ou sem temas, todos contribuíram para o processo de reconhecimento do Clube da Objetiva, tanto em âmbito local quanto no nacional. O clube passou a ser parte das atividades culturais de Goiânia, ao mesmo tempo em que se adequou às práticas do movimento fotoclubista. Portanto, foi legitimado como a instituição de associação de fotógrafos amadores representante da capital do estado de Goiás e do movimento fotoclubista.

Clube da Objetiva como seletor de imagens

fotoclube de Goiânia teve como base para a criação de suas atividades institucionais a prática de outros fotoclubes brasileiros, especialmente o Foto Cine Clube Bandeirante, de São Paulo. Existiria também uma aproximação em relação à prática fotográfica? De forma superficial, a resposta a esta questão é afirmativa, uma vez que fotoclubes fazem parte de um movimento de nível mundial, o fotoclubismo, com o desenvolvimento de uma prática fotográfica voltada à intenção de dar à fotografia o estatuto de "obra de arte", através de trocas de experiências entre integrantes dos clubes ou mesmo interclubes.

Uma das formas de troca de experiências era o envio de fotografias aos salões, de um clube para outro, como visto nos itens anteriores. $\bigcirc$ fotoclube promotor do salão recebia as fotografias e as selecionava. $\bigcirc$ resultado dessa seleção era o panorama fotográfico escolhido pela instituição, mas que mantinha relação com a representação imagética da prática fotoclubística vigente.

Neste sentido, o Clube da Objetiva, nos cinco salões nacionais que promoveu, escolheu as fotografias que deles deviam fazer parte. Com isso, mostrou o seu ponto de vista sobre o que é uma fotografia artística, mediante a aceitação em Salões Nacionais de Arte Fotográfica.

Assim, tal ponto de vista local estava intimamente coerente com o do movimento fotoclubista, na medida em que se baseava na experiência adquirida ao longo do desenvolvimento dos estilos fotográficos que o caracterizavam. Toma-se como pressuposto o "ponto de vista" 67 como experiência de um grupo excluído do discurso dominante ${ }^{68}$.

Trata-se do distanciamento do discurso ligado a um conceito fetichista de "arte", fundamentalmente antitécnico e que pressente seu fim no advento da própria técnica ${ }^{69}$. A tentativa do movimento fotoclubista é justamente a de dar um caráter artístico à fotografia, acreditando que, mesmo através da câmera fotográfica, um meio técnico, é possível obter um produto artístico.

Apesar de haver essa discordância, a tentativa de agregar um caráter artístico à fotografia dá-se de forma a adequar-se aos cânones vigentes de arte, ditados pela pintura, a partir da estética pictorialista. Com isso, há a preocupação em transformar a fotografia em uma obra única, eliminando o seu caráter de reprodutibilidade. 
Com isso, a cisão com o pensamento dominante não é radical. Contudo a partir dessa ligação pictórica começa-se a pensar a fotografia como arte, culminando em um pensar artístico para tal, tendo como representantes e semeadores desse ponto de vista as associações de fotógrafos amadores, os fotoclubes ${ }^{70}$.

Como, em um primeiro momento, há essa sujeição à arte dominante, na medida em que se pensa a arte ligada ao belo ${ }^{71}$, a fotografia praticada pelos fotoclubistas também faz essa associação. Portanto, é possível pensar os estilos fotográficos como possibilidades de um desenvolvimento estético, sejam com características que se aproximem da pintura ou não. Para isso, tanto em nível mundial quanto nacional, a prática fotográfica fotoclubista foi desenvolvida em um primeiro momento pela estética fotográfica do pictorialismo, mais tarde do modernismo, sofrendo influências, ainda, do fotojornalismo e da fotopublicidade.

Assim, existiria uma visualidade própria do movimento fotoclubista? Especificamente em relação ao Foto Cine Clube Bandeirante, que deu base à prática institucional do Clube da Objetiva, seria possível pensar em uma aproximação estética à sua produção fotográfica? Estas perguntas podem ser pensadas tendo em vista as escolhas que o fotoclube de Goiânia fez nos cinco salões. Aqui, o Clube da Objetiva é percebido em sua condição de seletor de imagens.

Para atingir esse objetivo e verificar uma possível relação com $\mathrm{FCCB}^{72}$, usa-se, como suporte deste texto, o entendimento das estéticas fotográfica presentes na história da fotografia em nível internacional e nacional, sendo as características da estética moderna apreendidas através de fotografias presentes na história da fotografia, para uma compreensão do contexto geral do seu desenvolvimento. $\bigcirc$ local entra em cena com o paralelo entre algumas fotografias do FCCB e as publicadas nos catálogos dos cinco salões nacionais promovidos pelo Clube da Objetiva, e por ele escolhidas.

As imagens foram tiradas de catálogos impressos em P\&B, portanto, não se leva em consideração a questão da cor, mesmo tendo sido escolhidas fotografias coloridas ou diapositivos. Parte-se do pressuposto de que são impressões em P\&B passíveis para se fazer a apreensão das estéticas do modernismo por meio da caracterização da forma de se retratar o objeto. Os catálogos compreendem 23 (1..), 97 (2.), 19 (3..), 62 (4.), e 17 (5.) fotografias impressas nos respectivos catálogos dos salões de Arte Fotográfica ${ }^{73}$.

Com isso, é possível constatar as características e influências na prática fotográfica dos fotoclubes das décadas de 1970 e 1980, com especial atenção ao Clube da Objetiva, neste momento visto como seletor de imagens, a fim de se verificar a sua forma de conceber a prática fotográfica e sua possibilidade como arte.

Como as fotografias foram escolhidas pelo Clube da Objetiva, na ocasião dos salões por ele promovidos, isso possibilita a percepção da existência ou não de uma relação com a estética moderna, ao apreender suas características, e, assim, a ligação deste fotoclube com o conceito fotográfico disseminado no fotoclubismo brasileiro, ou seja, a fotografia como produto artístico ${ }^{74}$.
70. A apropriação da estética pictorialista, pelo movimento fotoclubista se dá no fim do século XIX, na Europa No Brasil, isso ocorre somente em meados do século $\mathrm{XX}$, sobretudo com o Photo Club Brasileiro, no Rio de Janeiro; cf. Maria Teresa Bandeira de Melo (1998).

71. Ver Jean-Marie Schaeffer (1996).

72. Esse fotoclube foi escolhido devido à existência de pesquisas que contemplam o universo imagético, comprovando sua importância no desenvolvimento da fotografia moderna brasileira; ver, especialmente Helouise Costa eRenato Rodrigues da Silva (2004).

73. O universo de fotografias aceitas em cada salão é: 1 . (294); 2. (262); 3. (312); 4. (374); e 5. (403).

74. O objetivo é pensar a fotografia enquanto produto artístico a partir da visão de arte do movimento fotoclubista, tratado mais adiante sob o título Conceitos de arte fotográfica nas décadas de 1970 e 1980. 
75. Ver Philippe Dubois (1993, p. 254)

76. Cf. Paul Strand (1997, p. 780-781).

77. Idem, p. 780.

78. Paul Strand apud Susan Sontag (2004, p. 143).

79. Ver Jean-Marie Schaeffer (1996, p. 181)

80. Cf. Paul Strand (2003, p. 105-108).

81. Ver Edward Weston (2003).
Fotografia moderna

Do ponto de vista histórico, a relação entre arte e fotografia inicia-se com o movimento pictorialista ( 1890 - 1914), que demonstra o desejo da fotografia de "se fazer pintura"75. Para isso buscou na pintura bases para composição e enquadramento em sua materialização visual, a fim de reclamar o mesmo prestígio dado a ela, considerando, assim, a fotografia uma das belas-artes.

Em âmbito internacional, a proposta de arte fotográfica ligada ao pictorialismo começa a ser questionada no início do século XX. Um dos expoentes desse questionamento é o fotógrafo Paul Strand, na época integrante do Grupo Photo Secession. Em decorrência disso, em 1917, escreve em um dos últimos artigos da Camera Work76: "O poder potencial de todo meio é dependente da pureza de seu uso, e toda tentativa de mistura termina na morte de algumas coisas, como o colorir, tornando a fotografia em pintura fotográfica, a goma-bicromatada, etc., em que a introdução do trabalho manual e manipulações escondem a expressão em um impotente desejo de pintar"77.

Nesse sentido, Sontag recupera Strand, que, na década de 1920, escreve que o fato de "os produtos de uma câmera se enquadrarem na categoria de Arte é irrelevante"78. Logo, a autora vê a herança modernista avessa à preocupação de ser vista como arte, diferente de sua colocação no pictorialismo.

Com isso, a estética fotográfica passa de romântica a funcional. Schaeffer a conceitua como "uma estética cognitiva, mas [que] postula um conhecimento das formas e não um conhecimento dos objetos" "79. Uma cognição que passa a ser feita pela forma, e não pelo objeto em si, propiciando uma nova maneira de conceber o fazer fotográfico, que não necessariamente está no processo (como no pictorialismo), mas em sua visualidade.

Assim, a fotografia moderna surge em resposta às novas concepções de uso da câmera fotográfica, buscando uma formalização visual voltada à utilização dos meios fotográficos como expressão autônoma ${ }^{80}$

Em algumas fotografias de Strand, percebe-se a utilização de características próprias à estética fotográfica e materialização da estética funcional. Há uma valorização das formas em detrimento da referência a objetos, com o uso de valores tonais, texturas e linhas, sem o objeto aparecer como um todo.

Edward Weston ${ }^{81}$ também compartilha da ideia de que, pelas suas características ópticas e químicas, a fotografia pode ser usada de maneira criativa, por meio da variação do ângulo de tomada, uso de filtros ou pela mudança da iluminação.

Diferente dessa produção moderna iniciada pela crítica ao pictorialismo, Man Ray alia-se às vanguardas europeias, como o dadaísmo e o surrealismo, com uma produção também essencialmente fotográfica e sem a preocupação de estar fazendo arte ou não.

Além dos experimentos ópticos e químicos, Man Ray propunha experimentos visuais, compreendidos em três fases: os fotogramas e rayogramas 
(na década de 1920); as solarizações dos anos 30; e os desenquadramentos, com a inversão do ângulo de tomada ${ }^{82}$.

Fotografia moderna no Brasil

Com essa breve contextualização histórica da fotografia moderna em âmbito internacional, parte-se da concepção de que ela nasce no início do século $X X$, em consonância com as vanguardas europeias e a partir da problematização do potencial e das limitações da linguagem fotográfica. Contudo, no Brasil, ela só se manifesta em meados da década de 1940 e, ideologicamente semelhante aos Estados Unidos, como um questionamento ao pictorialismo, restringindo-se, entretanto, ao ambiente fotoclubista. Isso porque "o palco da renovação modernista foi o Foto Cine Clube Bandeirante (SP)"83. Helouise Costa defende que somente com a prática fotográfica do Foto Cine Clube Bandeirante o modernismo se estrutura de maneira sistemática, tendo como finalidade uma produção artística seguida de reflexão teórica ${ }^{84}$.

Já a autora Heloísa Espada ${ }^{85}$ argumenta que o desenvolvimento dessa fotografia moderna brasileira deu-se devido ao contato dos clubistas com a fotografia moderna norte-americana, com a vinda da exposição Fotografia artística $^{86}$. Segundo Espada, a modernidade fotográfica não fora construída fechada no Foto Cine Clube Bandeirante, uma vez que manteve contato com a fotografia internacional, cuja estética influenciou sobremaneira o desenvolvimento deste novo conceito de fotografia.

Apesar de Helouise Costa e Renato Rodrigues da Silva não mencionarem explicitamente tal influência do contato com fotógrafos estrangeiros, como expõe Espada, ambos vêem na fotografia a inserção de novas bases estéticas no interior do FCCB: "A modernidade se caracterizou pela intenção de recolocar a arte sobre bases estéticas, pretendendo negar a tradição pela renovação constante da expressão artística. Consequentemente, ela acabou por fundar uma outra tradição: a tradição do novo" 87 .

Segundo esses autores, a fotografia moderna surge do desejo da instauração de uma nova estética baseada na superação da perspectiva, sistema nascido no Renascimento e que sintetiza o modo de olhar do homem que a criou. Sobre a perspectiva, Arlindo Machado expõe: "A perspectiva central e unilocular inventada no Renascimento introduziu nos sistemas pictóricos ocidentais a estratégia de um efeito de 'realidade' e fez com que os seus artífices mobilizassem todos os recursos disponíveis para produzir um código de representação que se aproximasse cada vez mais do 'real' visível, que fosse o seu analogon mais perfeito e exato" 88 .

surgimento da fotografia veio carregado de um teor de realidade, encaixando-se perfeitamente no conceito de perspectiva. Na contramão disso, a fotografia moderna vem transformar o seu uso. Isso foi feito através da exploração de características da própria fotografia, como a linha, as formas, não
82. Cf. Antônio Fatorelli (2003, p. 111).

83. Ver Helouise Costa (2006, p. 144).

84. Apesar de examinar tal reflexão teórica, Helouise Costa a considera incipiente; ver Helouise Costa (2006).

85. Ver Heloísa Espada (2006).

86. Esta exposição aconteceu em 1947, na Biblioteca Municipal de São Paulo. Trazida do Museu de Arte Moderna de Nova York (MoMA), com imagens de Andréas Feininger, Helen Levitt, Ansel Adams, Ralph Steiner, Arthur Rothstein, Chaim Soutine, Charles Sheele, Eric Salomon, Louise Dahl Walfe, Henri-Cartier Bresson, Walder Evans, Berenica Abbot, Paul Strand, Edward Weston, Barbara Morgan e Cedric Wright; cf. Heloísa Espada (2006, p. 48).

87. Cf. Helouise Costa e Renato Rodrigues da Silva (1987, p.11).

88. Cf. Arlindo Machado (1984, p. 27). 
89. Cf. Helouise Costa e Renato Rodrigues da Silva (2004, p. 80).

90. Cf. Helouise Costa (2006, p. 144).

91. Termo utilizado em Helouise Costa e Renato Rodrigues (2004). Já Arlindo Machado utiliza a variante código perspectivo; ver Arlindo Machado (1984).

92. Cf. Helouise Costa e Renato Rodrigues da Silva (2004, p. 37). necessariamente condicionadas ao seu objeto, mas ao figurativismo. Com isso, há a busca de formas de representação visual voltadas ao abstracionismo. Logo, "a fotografia moderna tornou-se o elo entre duas realidades antagônicas da arte do século XX: a figuração e a abstração"89.

A construção desta nova estética fotográfica, uma estética moderna, foi feita por alguns fotógrafos pioneiros, a partir de suas pesquisas individuais, que, apesar de díspares, instauraram um novo olhar, caracterizando-se por uma clara ruptura com a prática acadêmica. Essa experiência fotográfica moderna passou por três fases: a Fase dos Pioneiros, a Escola Paulista e a diluição da experiência moderna, dentro do Foto Cine Clube Bandeirante ${ }^{90}$.

A fase dos Pioneiros é o período em que foram delineadas as principais características da fotografia moderna no Brasil, a partir da obra fotográfica de José Yalenti, Thomaz Farkas, Geraldo de Barros e German Lorca. Nas fotografias deles podem ser percebidos os elementos que caracterizam e dão sustentação à nova proposta estética.

Os Pioneiros do Foto Cine Clube Bandeirante trabalharam no sentido do experimentalismo, deslocado da questão puramente técnica para a construção de uma nova sensibilidade e a denúncia da arbitrariedade do "código perspético"91. Com isso, o desenvolvimento da fotografia moderna voltou-se para a exploração das potencialidades da luz, o uso do contraluz, a geometrização dos motivos, as especulações de ordem formal, enfatizando ritmos, planos e texturas, enquadramentos e ângulos inusitados, e as intervenções do processo fotográfico, a fim de questionar os limites da fotografia.

Essas características se encontram nos trabalhos desses fotógrafos pioneiros, que, apesar de terem trilhado caminhos distintos, embora complementares, objetivavam colocar a fotografia como meio de expressão autônomo, deixando de lado o seu caráter exclusivamente documenta ${ }^{92}$. Isso possibilitou pesquisas posteriores, mudanças na produção fotoclubista e, sobretudo, a consolidação de uma nova linguagem fotográfica. Para perceber-se isso, foram escolhidas quatro fotografias, uma de cada um destes pioneiros, a fim de traçar um paralelo com a produção fotográfica de alguns fotoclubistas atuantes nas décadas de 1970 e 1980

O objetivo principal é identificar, através do paralelo de imagens, as características que deram base à fotografia moderna no Brasil. E permitir que se perceba também o modo de adesão a essas mudanças de ordem estética por parte dos fotoclubes posteriores, inclusive do Clube da Objetiva, através da identificação das características da estética moderna de algumas imagens escolhidas pelo CO para que compusessem o conjunto fotográfico dos catálogos dos seus cinco salões nacionais.

Este paralelo imagético prevê a identificação das características da estética moderna, conforme expostas no panorama histórico da fotografia moderna. Assim, não se pretende fazer análise de imagens. Por isso, não foi escolhida uma metodologia de análise de imagens, mas propõe-se um diálogo entre as imagens, como expõe Boris Kossoy: "Podemos imaginar um diálogo entre as imagens e com as imagens? Creio que podemos imaginar como o fenômeno 
ocorre. Não se trata, obviamente, de um diálogo convencional. Trata-se de um diálogo mudo, subliminar, sensível e inteligente, que é gestado entre o nosso olhar e a nossa mente diante de uma foto ou de um conjunto de fotos"93.

Assim, será quem mesmo com um afastamento temporal entre o $\mathrm{CO}$ ( 1970-1980) e o FCCB (1940-1950), é possível verificar características comuns à estética moderna? Para isso, as fotografias serão colocadas em pares, para verificar as aproximações entre elas.

Umas das características marcantes da fotografia moderna, bastante explorada por José Yalenti, foi o uso do contraluz (Figura 3), em que o ponto de luz está atrás do objeto principal, que fica em silhueta, ou seja, mais escuro do que o resto da cena. A Figura 4 também utiliza esse recurso, criando uma outra referência para os objetos retratados, vistos mais em função de sua geometria do que do próprio referente. Além do elo quanto ao tipo de iluminação, há também entre as figuras 3 e 4 uma aproximação quanto ao assunto, ambos essencialmente urbanos, assunto moderno típico.
93. Cf. Boris Kossoy (2005, p. 36).

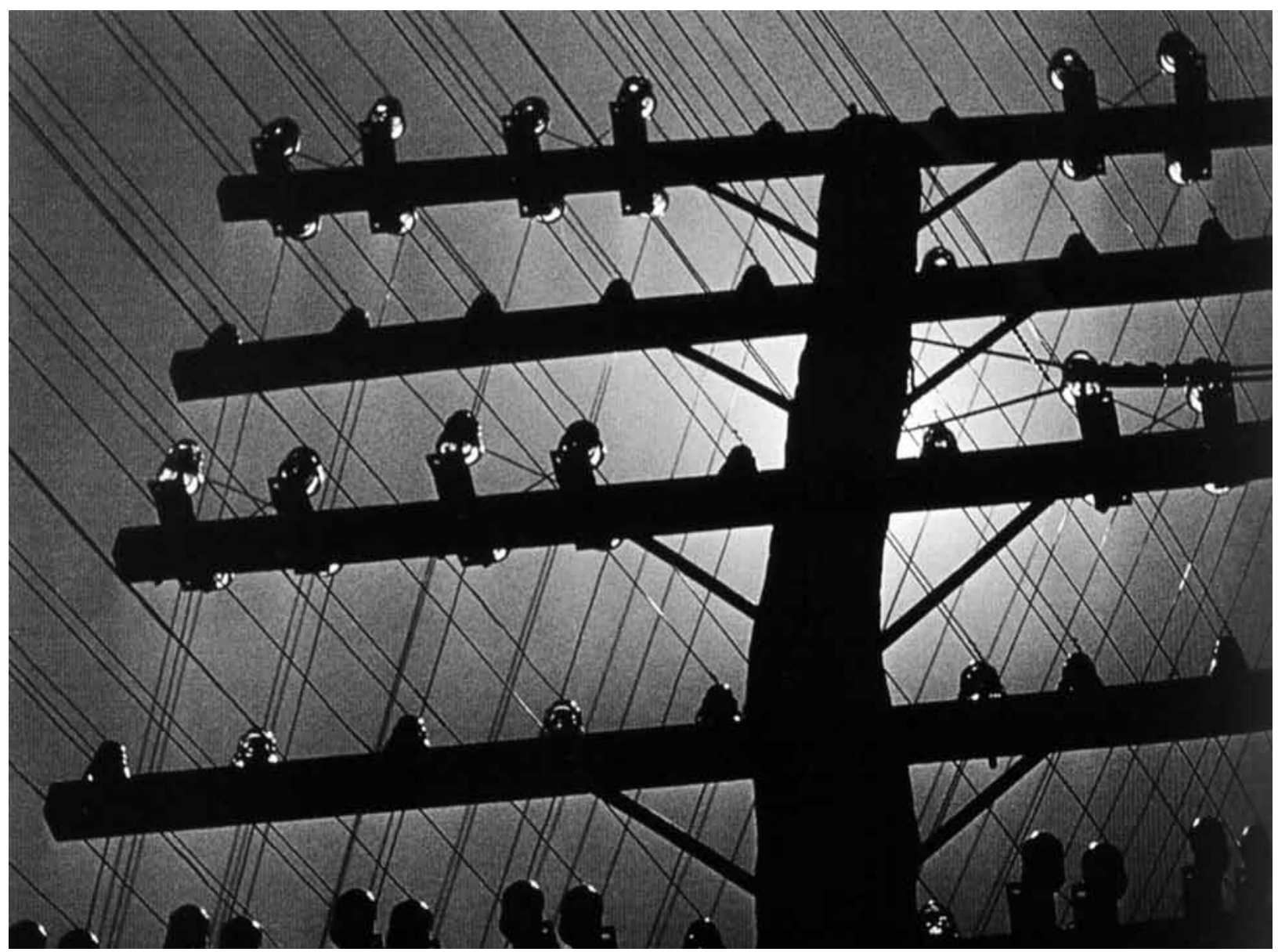

Figura 3 - José Yalenti (FCCB) - Energia / 1945. Costa; Silva, 2004, p. 132 


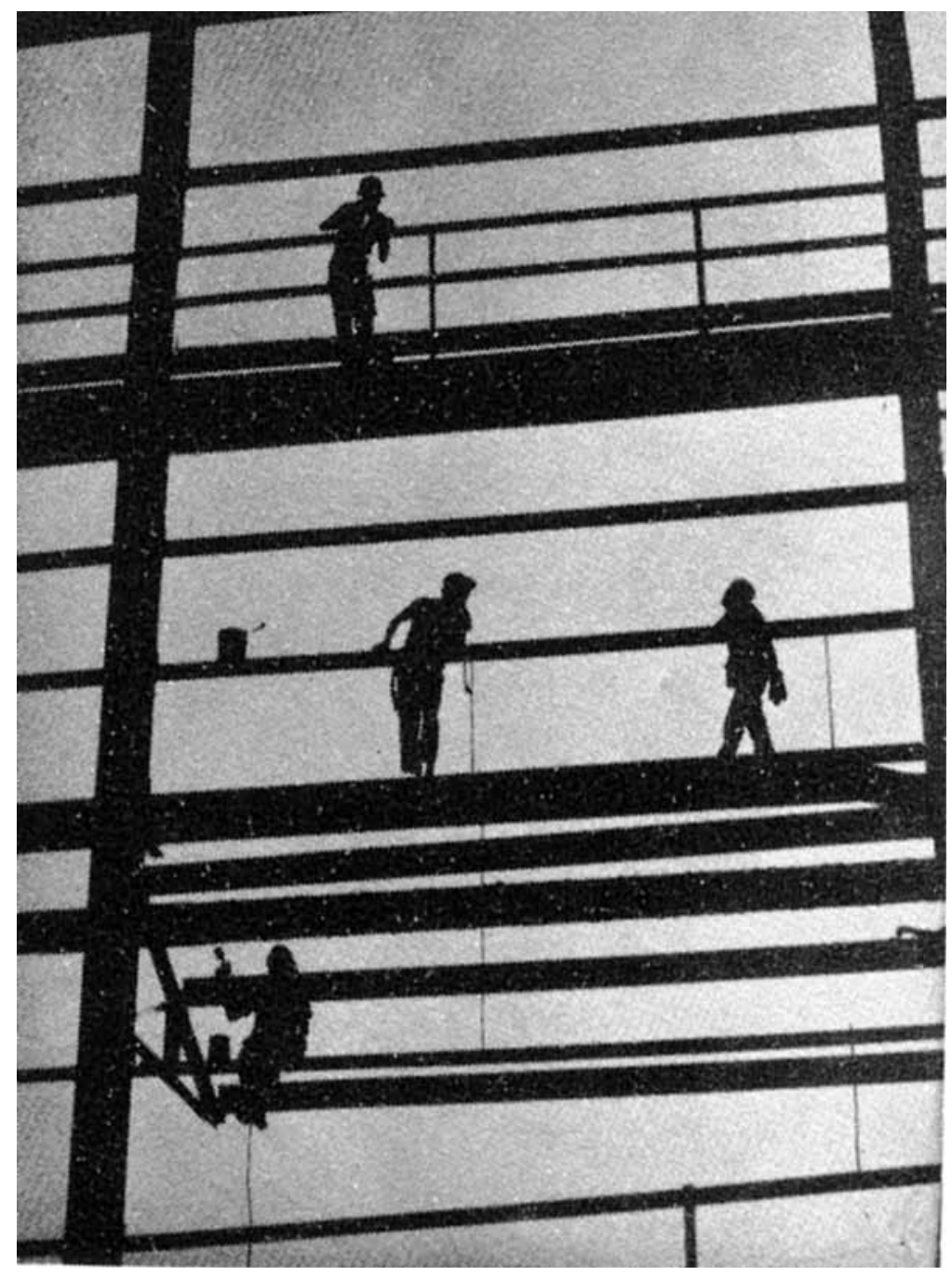

Figura 4 - Antônio J. M. Calino (CFFNVR) - Pintores / 1978. Catálogo do 2. Salão Nacional de Arte Fotográfica. Acervo do Clube da Objetiva (CO), Goiânia.

Assim como Yalenti, Thomaz Farkas (Figura 5) fez uso da fotografia direta, além de, dentre outros recursos, um enquadramento arrojado, propiciando uma outra visão ou mesmo o estranhamento do referente. Como se percebe, o assunto é a cidade, no caso a barragem de uma usina. Quanto a isso, a figura 6 se afasta, mantendo uma relação com a fotografia de Farkas no que tange a esse enquadramento criador de uma nova visualidade. Além de perceberem-se essas aproximações com a fotografia moderna, a imagem mostra a diferença em relação ao pictorialismo, no que diz respeito ao registro da nudez feminina, cujo enquadramento seria mais aberto.

Por caminhos diferentes, Geraldo de Barros trabalha a fotografia moderna fazendo uso de experimentações de laboratório, recortes, superposições, 


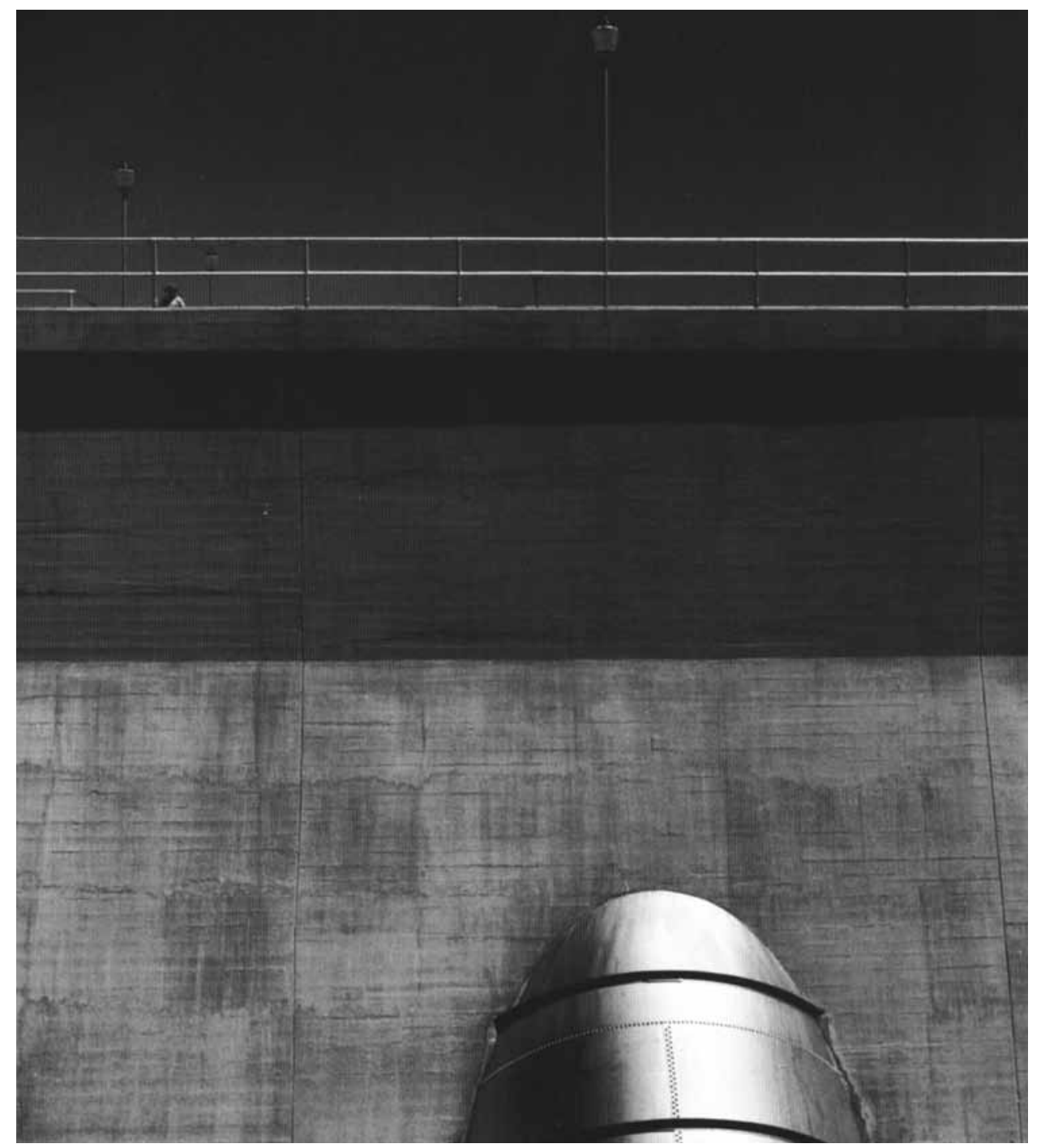

Figura 5 - Thomaz Farkas (FCCB) - Barragem de usina / 1951. Acervo do fotógrafo no Instituto M oreira Salles.

desenhos feitos no negativo, fotomontagens e fotogramas, questionando os limites da fotografia, como mostra a figura 7. A figura 8 , de Walter Brugger, também mostra essa inventividade, através do uso da fotomontagem, passando a mensagem de "Pare a polvição" pela exploração da plasticidade fotográfica.

German Lorca seguiu tanto a fotografia direta quanto a intervencionista. Contudo, a figura 9, vai ao encontro da manipulação fotográfica, com a aplicação da técnica de solarização, possibilitando a abstração do referente. A figura 10 também faz uso dessa técnica, o que propicia uma nova visualidade acerca do retrato, assim como no do homem retratado por Lorca. Apesar de enquadramentos distintos, a técnica une essas imagens, especialmente por transformar a suas referências. 


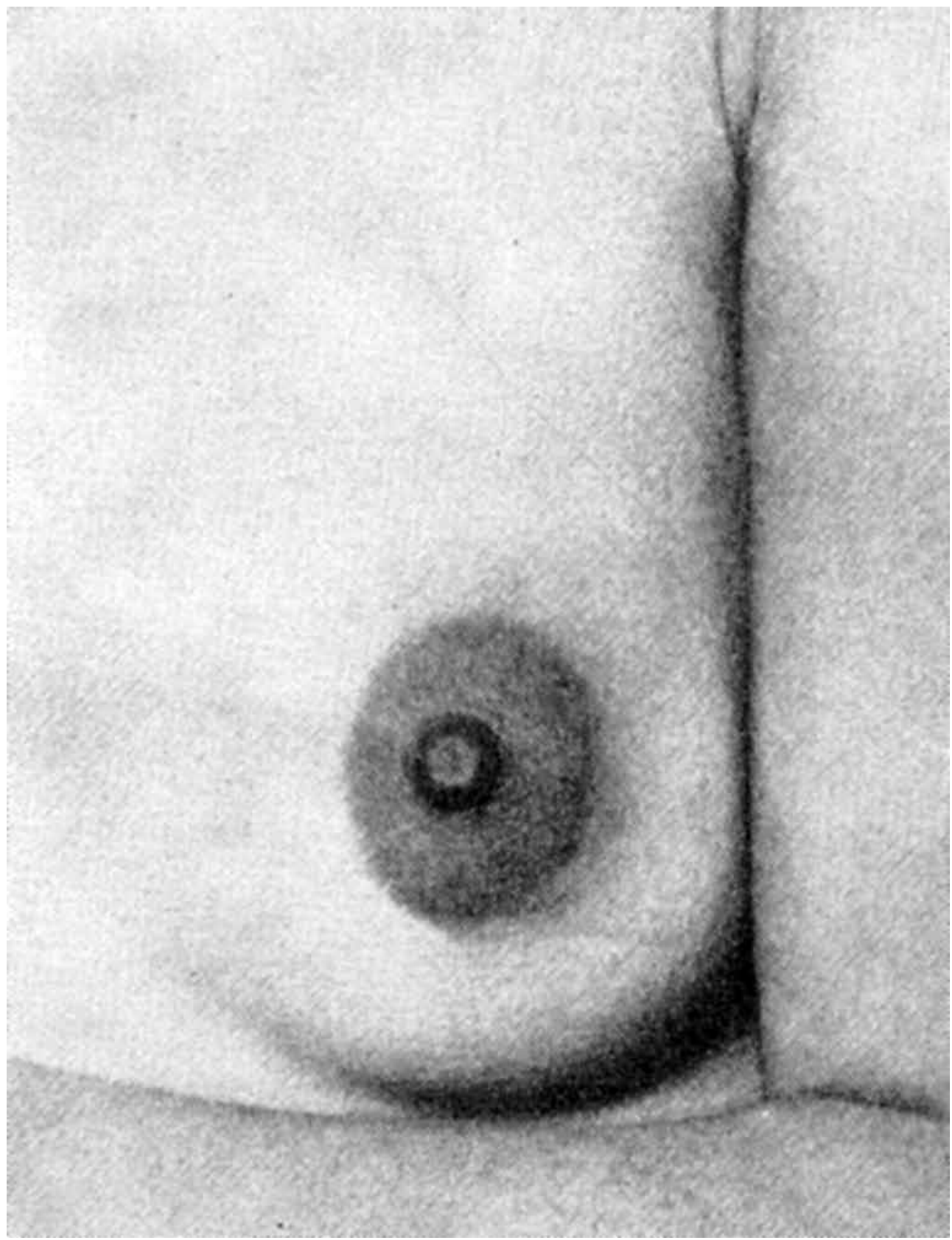

Figura 6 - Frederico Mielenhausen (CGF) - Seio / 1987. Catálogo do 5. Salão Nacional de Arte Fotográfica. Acervo do Clube da Objetiva (CO), Goiânia. 


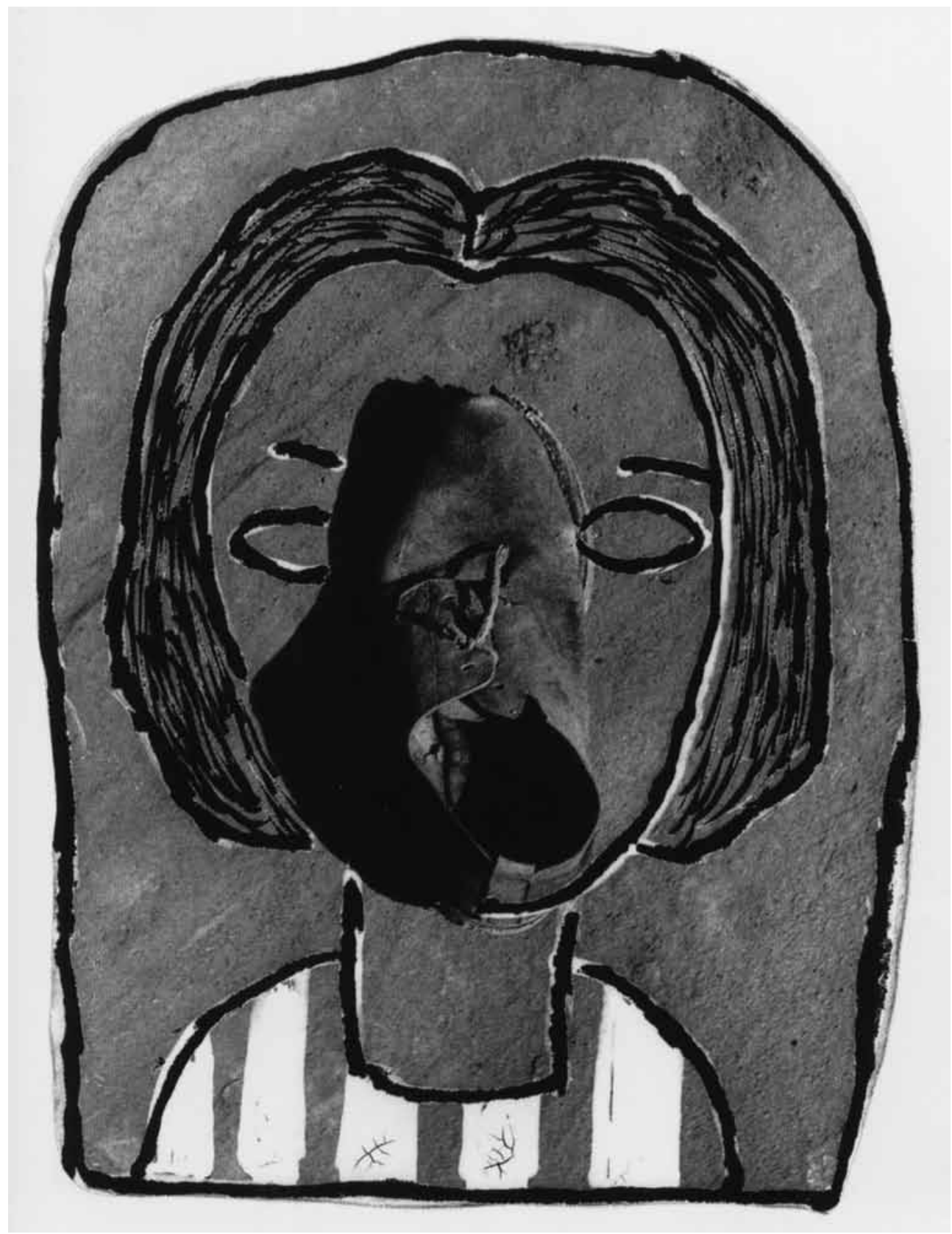

Figura 7 - Geraldo de Barros (FCCB) - A menina do sapato / 1949. Acervo do fotográfo sob guarda da família. 


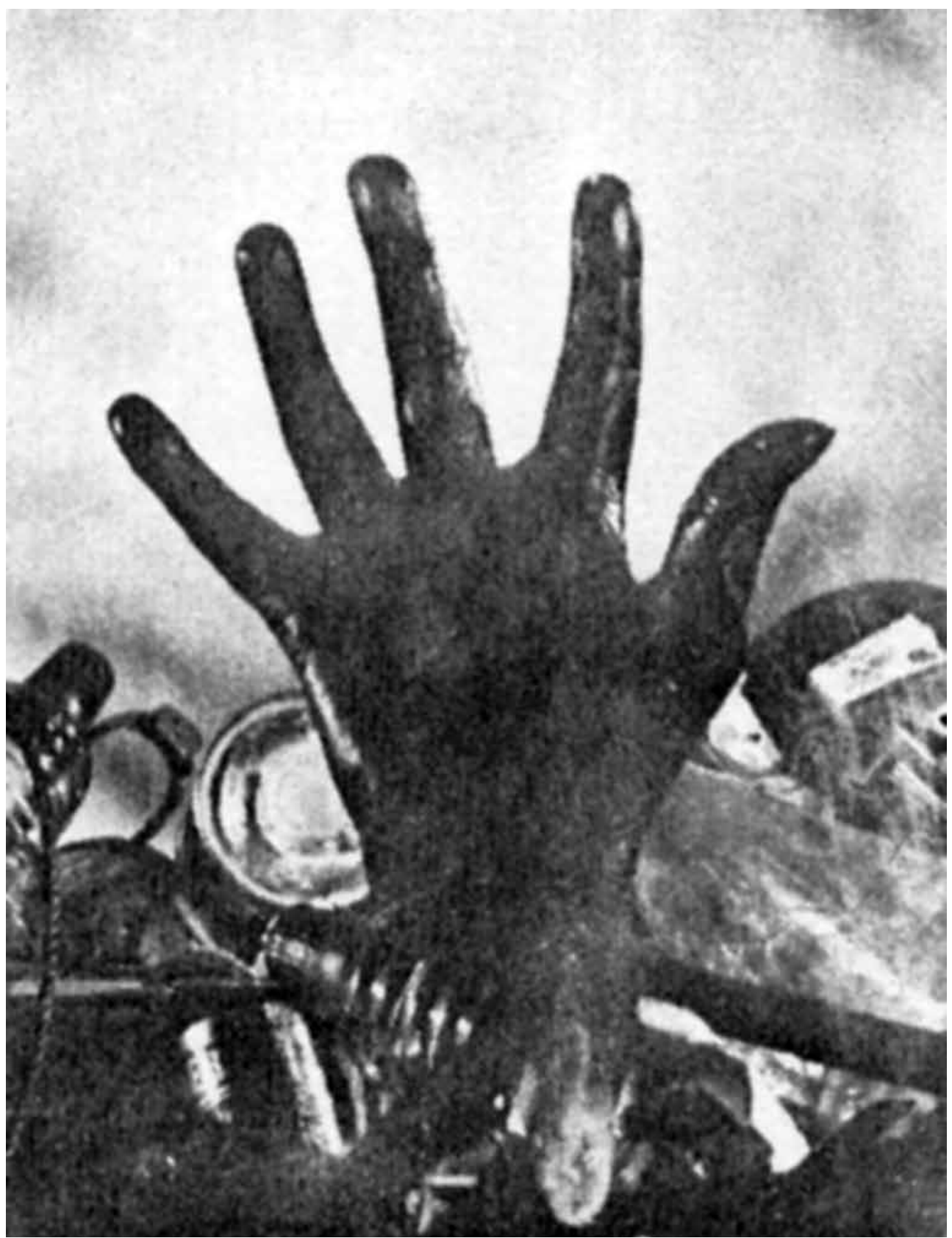

Figura 8 - Walter Brugger (CFACS) - Stop Pollution no 3 / 1987. Catálogo do 5. Salão Nacional de Arte Fotográfica. Acervo do Clube da Objetiva (CO), Goiânia. 


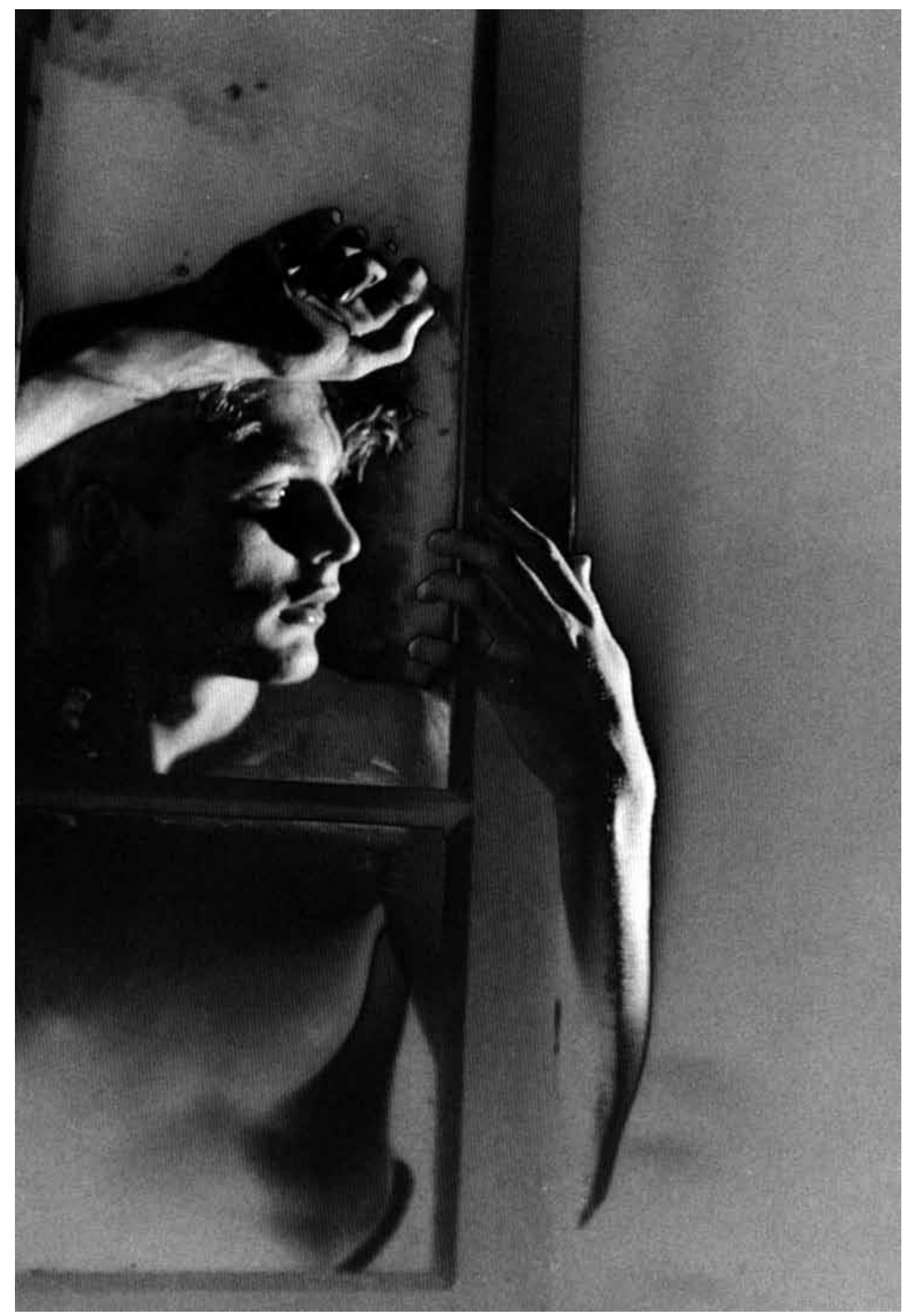

Figura 9 - German Lorca (FCCB) - Le diable au corps / 1949. Acervo do fotográfo. 


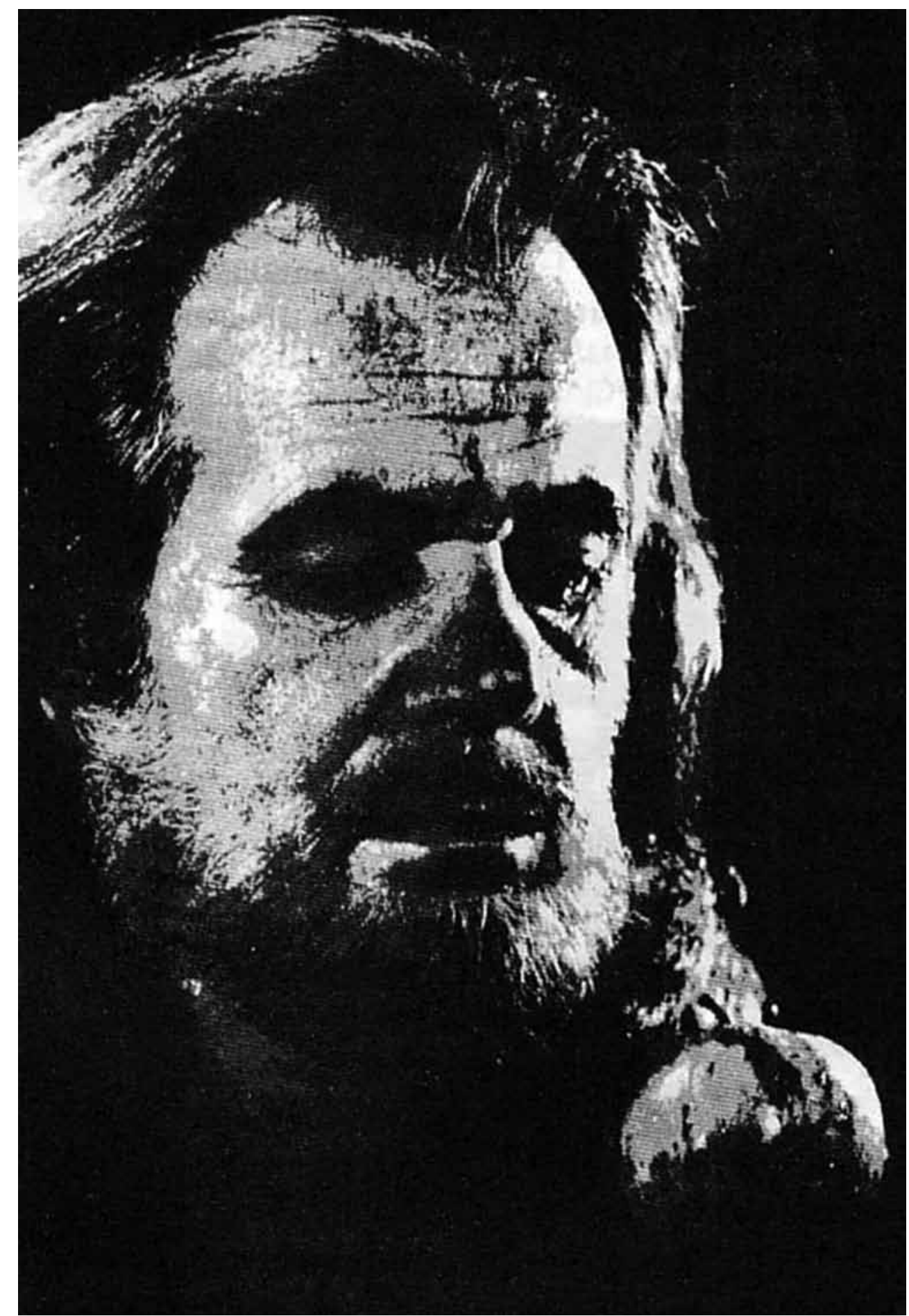

Figura 10 - Delcio Capistrano (ACF) - Tentação / 1980. Catálogo do 3. Salão Nacional de Arte Fotográfica. Acervo do Clube da Objetiva (CO), Goiânia. 
A forma de utilização da sombra na fotografia moderna adquire nova feição, como mostra a imagem de Salvatore (Figura 111), em que a sombra não só cria o equilíbrio no quadro, como fazia no pictorialismo, mas torna-se um elemento de expressão autônoma. Uso semelhante da sombra está na figura 12, em que as duas sombras de pessoas são os elementos de maior atenção e os objetos à volta tornam-se secundários. A sombra transforma-se no fundamento dessa imagem.

Esses quatro retratos fazem parte dos catálogos do Clube da Objetiva e servem para que se perceba a diferença em relação ao pictorialismo ao se trabalhar o tema. $\bigcirc$ contraste entre preto-e-branco, luz e sombra, tornam-se fundantes, realçando a geometrização e perda da referência do objeto. Isso possibilita uma nova visualidade, além de criar uma nova relação com a perspectiva. Nessas quatro figuras 13, 14, 15 e 1694, os retratados parecem estar em um único plano, achatado, não existe nada além.

Com isso, são ressaltadas as linhas e formas de cada uma das pessoas, que acabam perdendo as características de um ser humano comum. Em Gabriela, a mulher está cortada por linhas e parece ter perdido parte da face devido à iluminação escolhida. Já os retratados de Alma branca e Obscuromisturam-se com - fundo, perdendo alguns elementos do rosto humano. $\bigcirc$ enquadramento desconcertante de Man corta, de forma abrupta, o olhar do retratado, envolto por um negro intenso.

Percebe-se, pelas imagens acima, uma grande aproximação entre a estética moderna dos anos 1940 e 1950 e a de 1970 e 1980. Além das características citadas através das imagens, vê-se que, apesar de ter havido uma mudança radical em relação à estética do pictorialismo no que tange à sua visualidade, ainda há uma relação com temas e títulos desse movimento. Embora se crie um distanciamento referencial, como nas figuras 5 e 6 - respectivamente, Barragem da usina, de Thomaz Farkas, e Seio, de Frederico Mielenhausen -, há um direcionamento do que é o objeto através dos respectivos títulos, retornando o olhar ao seu referente.

Conclui-se que a fotografia moderna acabou mostrando uma outra possibilidade visual, diferente daquela feita inicialmente no interior do movimento fotoclubista. Não quer dizer, como se percebe pelas fotografias dos catálogos em questão, um abandono de práticas pictorialistas, mas a agregação das modernas, sem muito questionamento, uma assimilação espontânea daquilo que era visto nas imagens de outros salões e catálogos.

movimento fotoclubista caminhou esteticamente balizado nesses dois movimentos, tornando-se possível um intercâmbio maior entre os fotoclubes, com a troca de experiências. Isso se deu por meio da criação de uma instituição com o intuito de organizar e unir as diversas associações.

Em dezembro de 1950, durante a 1.․․ Convenção Nacional de Arte Fotográfica, promovida pelo Foto Cine Clube Bandeirante, com a presença de todos os fotoclubes existentes no país, foi criada a Confederação Brasileira de Fotografia e Cinema (CBFC), que passou a representar o Brasil na Fedération Internationale de l'Art Photographie (FIAP).
94. Apesar de ser de autoria de uma fotógrafa do Clube da Objetiva, a Figura 22 foi colocada aqui por fazer parte do catálogo do 5 . Salão Nacional e criar um diálogo com as demais. Mas, neste momento, o objetivo não é o de apresentar fotografias dos integrantes do clube mas das imagens aí escolhidas para compor o conjunto fotográfico dos catálogos de seus salões nacionais, algumas delas selecionadas por possibilitar a percepção de relações com a estética moderna. 


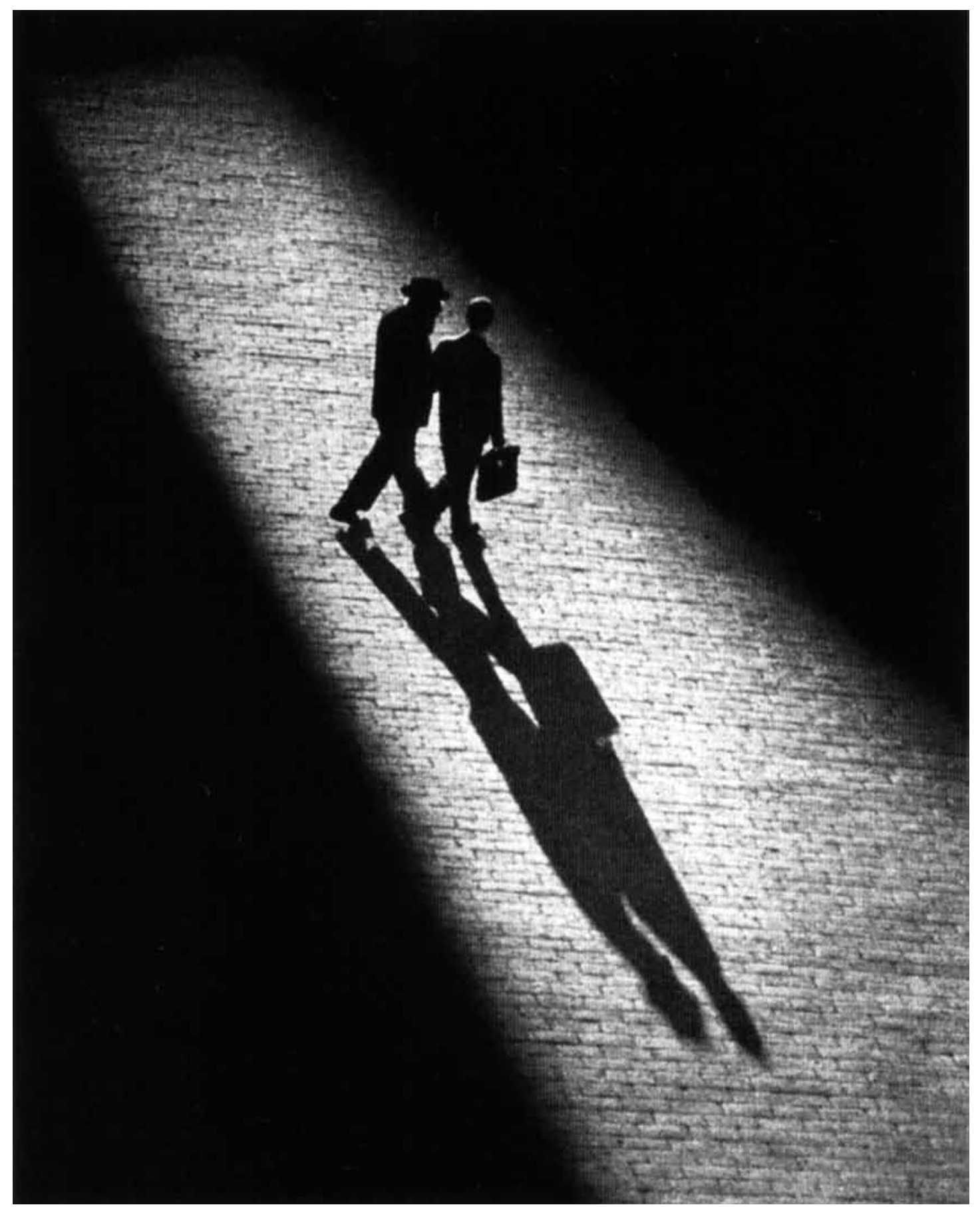

Figura 11 - Eduardo Salvatore (FCCB) - Sombras da tarde / 1948. Acervo do fotográfo sob guarda da família. 


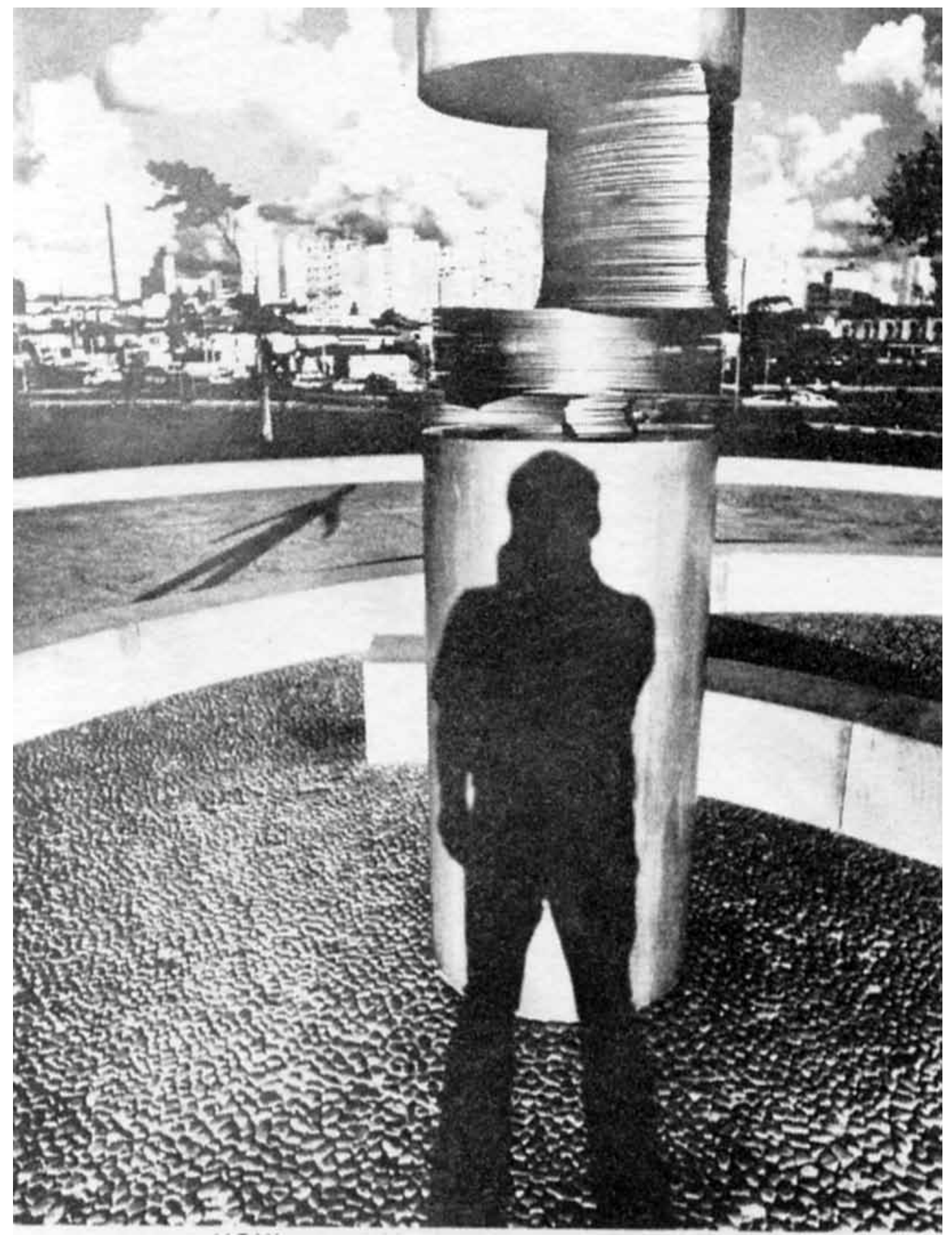

Figura 12 - Frederico Mielenhausen (CGF) - Silhuetas / 1981 . Catálogo do 4. Salão Nacional de Arte Fotográfica. Acervo do Clube da Objetiva (CO), Goiânia. 


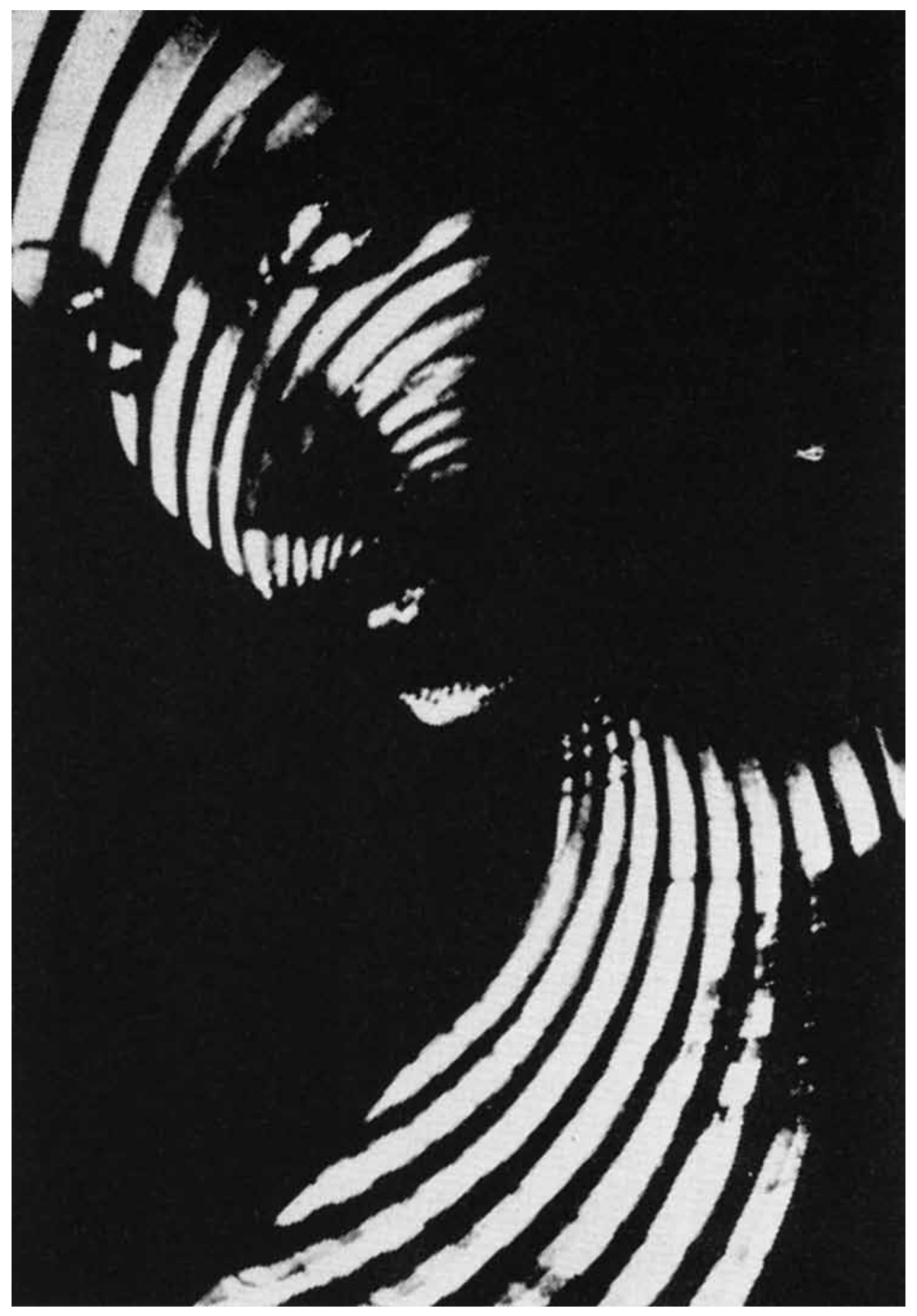

Figura 13 - Décio Brian (SFNF) - Gabriela / 1977. Catálogo do 1.Salão Nacional de Arte Fotográfica. Acervo do Clube da Objetiva (CO), Goiânia. 


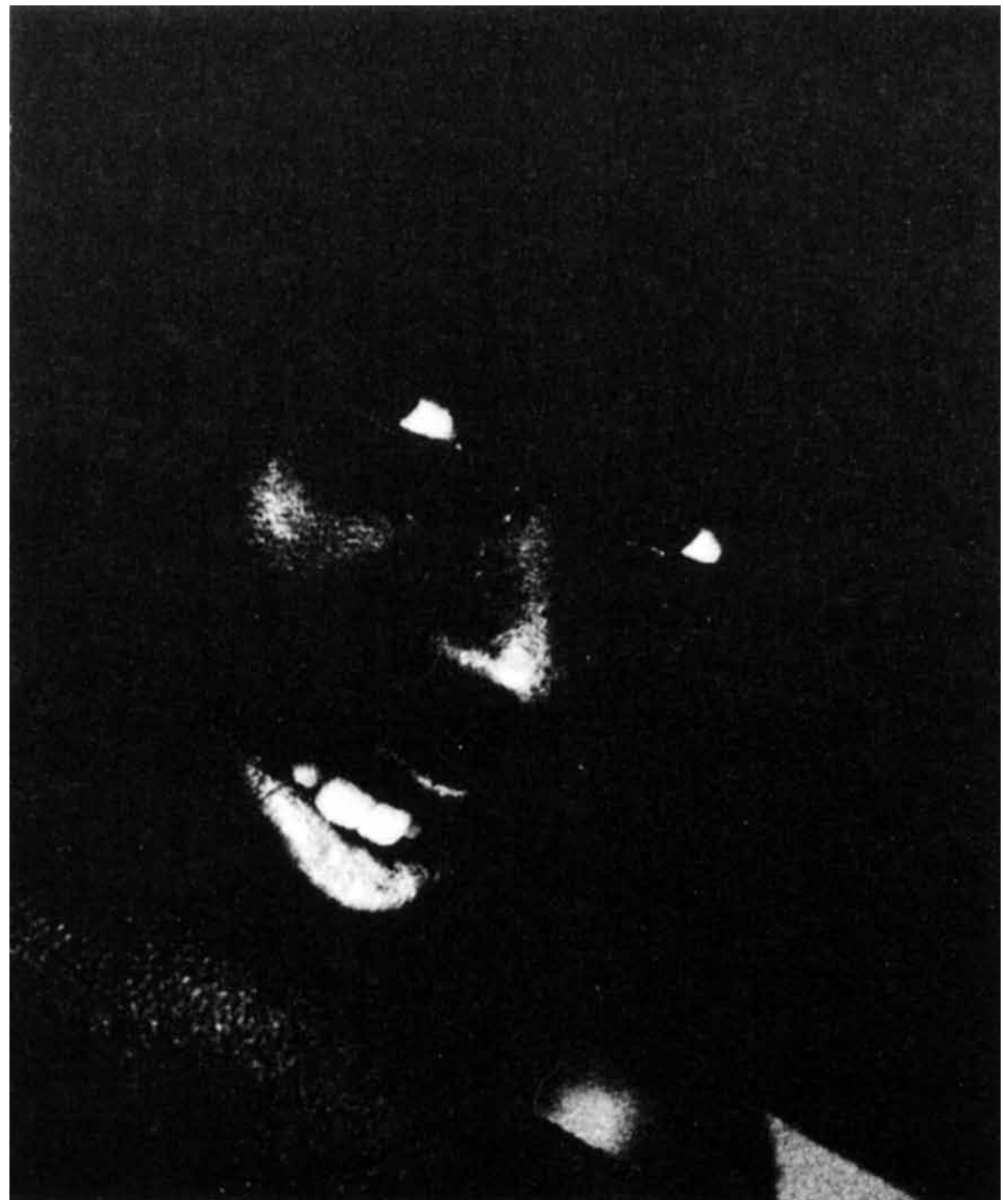

Figura 14 - Rui Mello Porto (FCL) - Alma Branca/1980. Catálogo do 3. Salão Nacional de Arte Fotográfica. Acervo do Clube da Objetiva (CO), Goiânia. 


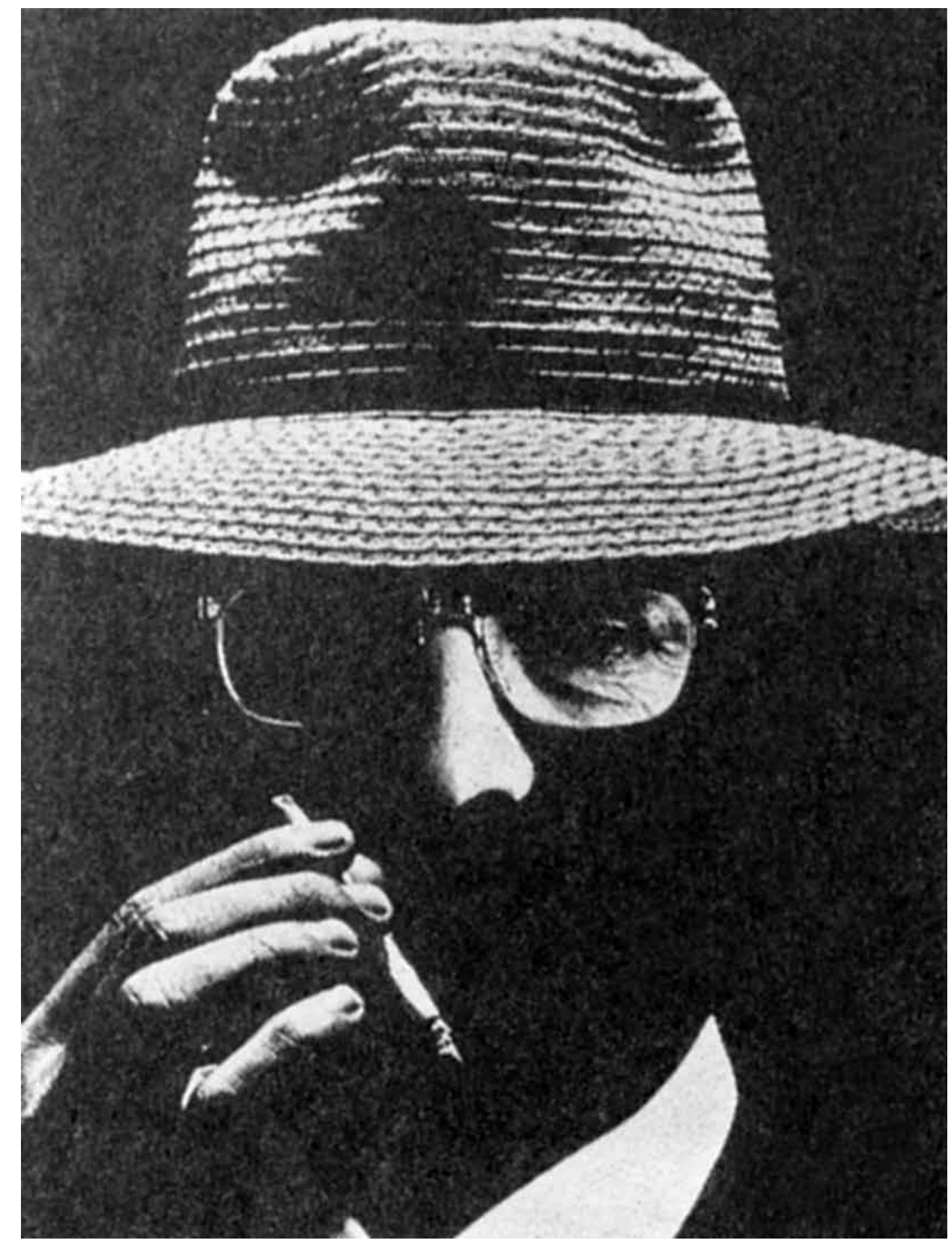

Figura 15 - Álvaro de Pereira Gomes (ACF) - Obscuro / 1987. Catálogo do 5. Salão Nacional de Arte Fotográfica. Acervo do Clube da Objetiva (CO), Goiânia. 


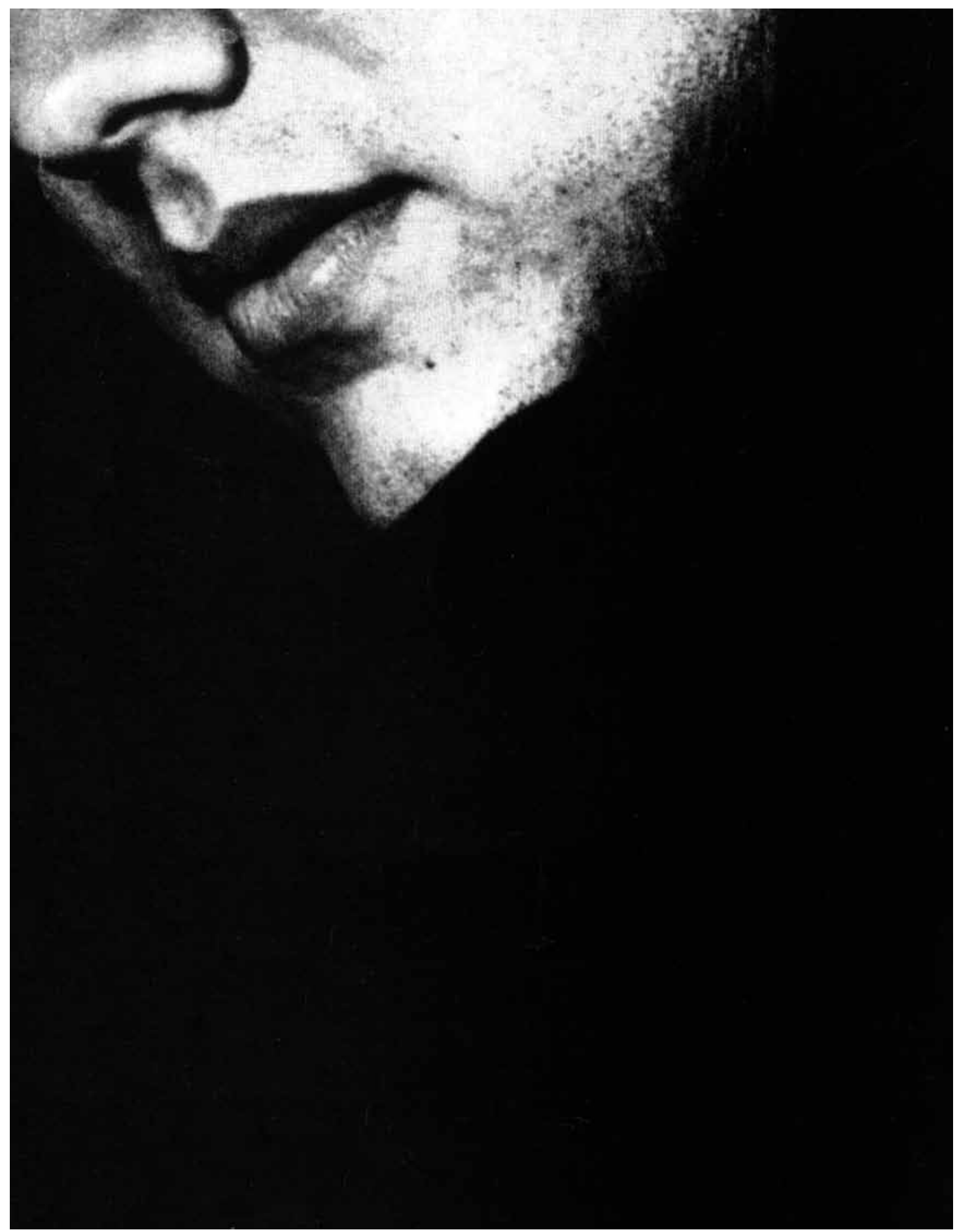

Figura 16 - Sílvia de Souza (CO) - Man / 1987. Catálogo do 5. Salão Nacional de Arte Fotográfica. Acervo do Clube da Objetiva (CO), Goiânia. 
95. O termo Escola Paulista foi criado pela crítica das revistas especializadas da época para designar a produção moderna do FCCB

96. Cf. Helouise Costa e Renato Rodrigues da Silva (2004, p. 61)

97. Idem, p. 95

98. Os conceitos aqui tratados relacionam-se ao modo como o movimento fotoclubista no Brasil concebe a arte fotográfica.
Com isso, o movimento fotoclubista adquire um alto nível de organização, havendo inúmeros salões pelo país, e intenso intercâmbio entre os fotoclubes, com a publicação de seus boletins informativos e também da revista Íris, que circulava desde 1947, a primeira revista de caráter comercial sobre fotografia.

Nesse contexto do movimento fotoclubista, surge a Escola Paulista de Fotografia ${ }^{95}$, que, paralelamente ao trabalho dos pioneiros, fotografava com o objetivo de criar uma nova sensibilidade artística, com a quebra das regras clássicas de composição, uso do claro-escuro radical, ênfase nas linhas, ressaltando o caráter abstrato, geometrização dos motivos e quebra da integridade do processo fotográfico tradicional.

Segundo Helouise Costa e Renato Rodrigues da Silva, "A força e a originalidade da Escola Paulista fizeram com que a fotografia chegasse finalmente aos museus, impondo o reconhecimento da crítica de arte que até então havia se mostrado totalmente alheia a essa forma de expressão"96.

Em 1949 aconteceu exposição de Thomaz Farkas, no Museu de Arte Moderna (MAM). Neste ano, o Museu de Arte de São Paulo (MASP) organizou um laboratório fotográfico no museu, pelo qual Geraldo de Barros, Thomaz Farkas e German Lorca ficaram responsáveis. A partir daí, aconteceram outras exposições, como a de Geraldo de Barros, no MASP, em 1950; de German Lorca, no MAM-SP, em 1952; a da Escola Paulista, em sala especial na II Bienal Internacional de São Paulo, em 1953; de Ademar Manarini, no MAM-SP, em 1954; e, em 1956, de José Mauro Pontes e Eduardo Ayrosa, no foyer do Teatro Maria Della Costa.

No fim da década de 1950, a experiência moderna no interior do Foto Cine Clube Bandeirante começou a diluir-se. Contudo, ainda permaneceu um grupo que deu continuidade à Escola Paulista, produzindo trabalhos que conduziram a um novo figurativismo, de cunho humanista e que redefiniu os rumos da modernidade ${ }^{97}$.

Essa continuidade da utilização da estética moderna pode, inclusive, ser percebida nos fotoclubes da década de 1970 e 1980, e, também, no Clube da Objetiva, como seletor de imagens e, por isso, conivente com a agregação dessa estética funcional.

Conceitos de arte fotográfica nas décadas de 1970 e $1980^{98}$

Pouco ou quase nada tem sido escrito sobre o que houve com o movimento fotoclubista brasileiro após os anos 1960, seja em relação a sua produção seja quanto à teorização de sua estética fotográfica. Por isso, aqui estão colocadas reflexões sobre como as estéticas fotográficas desenvolvidas no interior do fotoclubismo contribuíram com o desenvolvimento da fotografia artística. Isso é verificado a partir da produção fotográfica dos fotoclubes da época e de 
escritos publicados em boletins-informativos e revistas de fotografia guardados no acervo do Clube da Objetiva.

Percebe-se que, apesar do intervalo temporal em relação ao fotoclubismo em nível internacional, foram agregadas algumas características, tanto em relação ao pictorialismo quanto à concepção de fotografia moderna, sobretudo como havia sido difundido no Foto Cine Clube Bandeirante.

Desde o início do movimento fotoclubista, houve uma tentativa de padronização de técnicas, o que foi parcialmente conseguido através do intercâmbio entre fotoclubes, possibilitando a criação de uma base de funcionamento comum. Essa prática de intercâmbio, tanto de fotografias quanto de informações, através da veiculação de boletins-informativos, cartas e catálogos aconteceu nas décadas de 1970 e 1980.

Por isso, parte-se dos escritos de alguns boletins informativos 99 encontrados no acervo do CO para se entender as principais características que contribuem para a construção do conceito de fotografia artística no interior do movimento fotoclubista, o que já cria uma relação com a estética pictorialista. Além da obra de arte relacionada ao estilo do autor (sentimento, personalidade, individualidade); controle de todas as etapas do fazer fotográfico, assegurando a geração de uma cópia única, e práticas fotográficas ligadas à fotografia manipulada e pura.

Nota-se, então, a existência de uma ligação ainda muito forte com o pictorialismo. Claro que algumas técnicas foram substituídas, como o bromóleo, a gomabicromata, mas havia ainda a tentativa da geração de uma cópia única, através de fotomontagens, por exemplo.

Nos textos dos fotoclubistas, porém, não há essa referência direta ao pictorialismo, em que o termo seja utilizado ou se faça um apanhado ou estudo das fotografias do século XIX ou início do XX. Entretanto, é clara a tentativa de dar "ares" de arte para a fotografia, buscando uma sensibilidade visual que ultrapassa a representação pura do real, criando assim uma disposição quanto ao pensar e desenvolver uma arte fotográfica no interior dos fotoclubes brasileiros nas décadas de 1970 e 1980.

Essa discussão entre arte e fotografia, além de se ligar ao pictorialismo, principalmente no conceito da produção de uma obra única, mantém também relação com a fotografia moderna, pela teorização dos seguintes temas: expressão do artista enquanto marca e visão pessoais, comunicação da obra com o público, e fotógrafo amador. Contudo, assim como com a relação ao pictorialismo, não há uma menção direta à fotografia moderna.

Mas é possível apreender características do pictorialismo e da fotografia moderna não só na sua produção fotográfica como também na tentativa dos fotoclubes de teorizar sobre o fazer fotográfico, expressa nos textos dos boletins informativos e nas revistas da época, mesmo que tais termos não sejam utilizados explicitamente.

Algumas revistas de fotografia da época acabavam constituindo um espaço de discussão do fotoclubismo brasileiro. Dentre elas destacam-se Fotoarte, Foca e Fotoptica. Tanto a primeira quanto a segunda parecem ter uma grande
99. Os boletins informativos pesquisados pertencem aos seguintes fotoclubes: Foto Cine Clube Bandeirante, Associação Brasileira de Fotografia, Clube Foto Amigos de Santos e Confederação Brasileira de Fotografia. Na bibliografia estão relacionadas as edições utilizadas neste texto. 
100. Francisco Aszmann, fotógrafo húngaro radicado no Rio de Janeiro.

101. Apesar de haver este contato com fotógrafos e fotografias fora do ambiente clubista, não é possível dizer se existia discussão sobre os mesmos, ou como se dava a circulação dessas revistas dentro do CO. Apenas se sabe da existência das revistas, mas não de seu modo de circulação ou de seus conteúdos.

102. Dr. Olavo Nery, médico, era um veterano da Abaf. Dados extraídos de Olavo Nery (1977). ligação com o movimento fotoclubista, porque seus conteúdos, como textos e fotografias, discutem a estética dos fotoclubes.

Na Fotoarte (Figura 17), um dos redatores e diretor artístico era Francisco Aszmann ${ }^{100}$, membro da Associação Carioca de Fotografia. Além do mais, havia textos sobre a arte fotográfica, como na edição n. 189 da revista, de 1974, em que Heber Jardim propõe a integração e a cooperação entre as artes, pintura, gravura, escultura e fotografia, sendo que a última poderia regulamentar formas de julgamento em salões e concursos, por já possuir tabelas e critérios menos abstratos de julgamento, sistemas de financiamento de salões e programas de organização.

A Foca (Figura 18) também "encarnava" o espírito do fotoclubismo, além de abrir espaço para textos e imagens desses fotógrafos-artistas. Os textos assemelhavam-se aos dos boletins dos fotoclubes, ora sobre técnicas, ora sobre estética fotográfica, além de calendários de exposições, salões e concursos promovidos pelos clubes. Na edição n. 81 da revista, de setembro de 1981, por exemplo, a fotografia da capa é de autoria de um membro do Íris Foto Grupo, Paulo Pires, com apresentação do portfólio do fotoclubista Délcio Capistrano, da ABAF.

Diferente dessas duas revistas, a Fotoptica (Figura 19) apresenta um teor mais voltado para o fotógrafo profissional (publicidade, casamento) e não para o fotoclubista, cuja produção acaba sofrendo influência do fotojornalismo e da fotopublicidade. Na edição da Fotoptica de setembro e outubro de 1985, por exemplo, há matérias com os títulos Como ser um fotógrafo profissionale e Fotografia na capa de disco e o artigo Quanto vale o seu clic? Há, ainda, a apresentação de portfólios, como os dos fotógrafos profissionais J. R. Duran, David Drew Zingg e Márcia May. Logo, existe o contato dos integrantes do clube com o que se estava produzindo na época, mesmo fora do ambiente clubista ${ }^{101}$.

Já os boletins informativos, mensais ou bimestrais, em geral seguiam o mesmo padrão. Continham informes sobre concursos, salões e exposições da época, atividades internas e textos que discutiam a relação entre fotografia e arte, produzidos por membros do próprio clube ou de outros.

No Boletim da ABAF, de novembro e dezembro de 1977, Olavo Nery ${ }^{102}$, por exemplo, discute essa relação, partindo do pressuposto de que arte "é a expressão de um ideal realizado em forma plástica", e que a fotografia, artisticamente realizada, se enquadra nesse conceito.

Para Olavo Nery, o conceito de criação, implícito na ideia de arte, é evidenciado nas escolhas feitas pelo fotógrafo para a "conclusão" de sua mensagem, e relacionadas ao assunto, à originalidade, ao apelo, à composição e ao bom gosto, ângulo de tomada e originalidade da iluminação. Logo, a arte, de acordo com Nery, está relacionada à intuição, mesmo as artes mais diretas, como a fotografia:

Neste particular, deve ser sempre lembrado que a arte não se dirige à percepção consciente, mas à apreensão intuitiva. A presença da obra de arte não se faz sentir ao nível da inteligência, mas da emoção. É mais um símbolo do que a afirmação de uma verdade, por mais direta que ela seja, como é o caso da fotografia. Podemos dizer que o racional não preside 


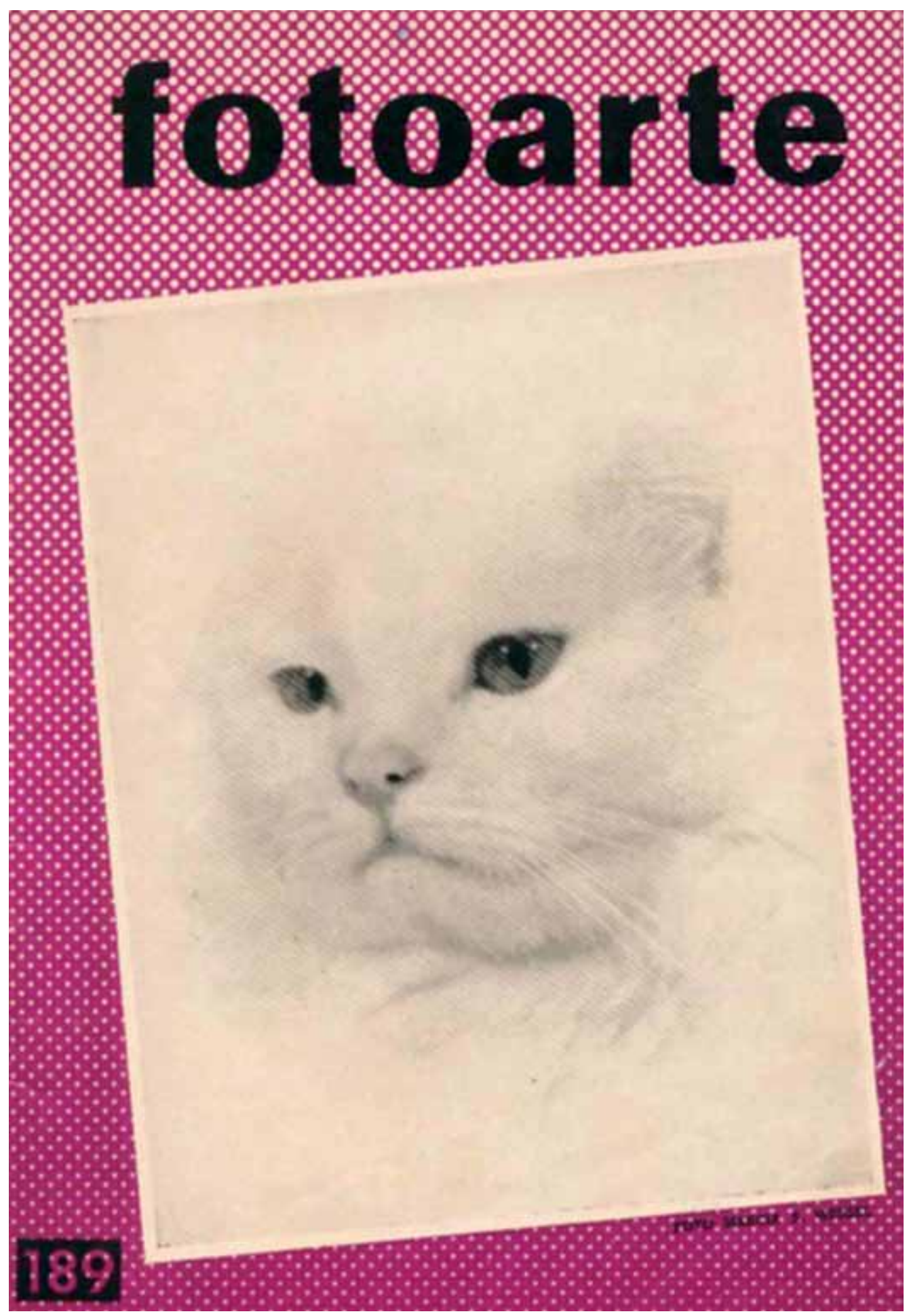

Figura 17 - Capa da revista Fotoarte, ํo 189, 1974. Acervo do Clube da Objetiva (CO), Goiânia. 


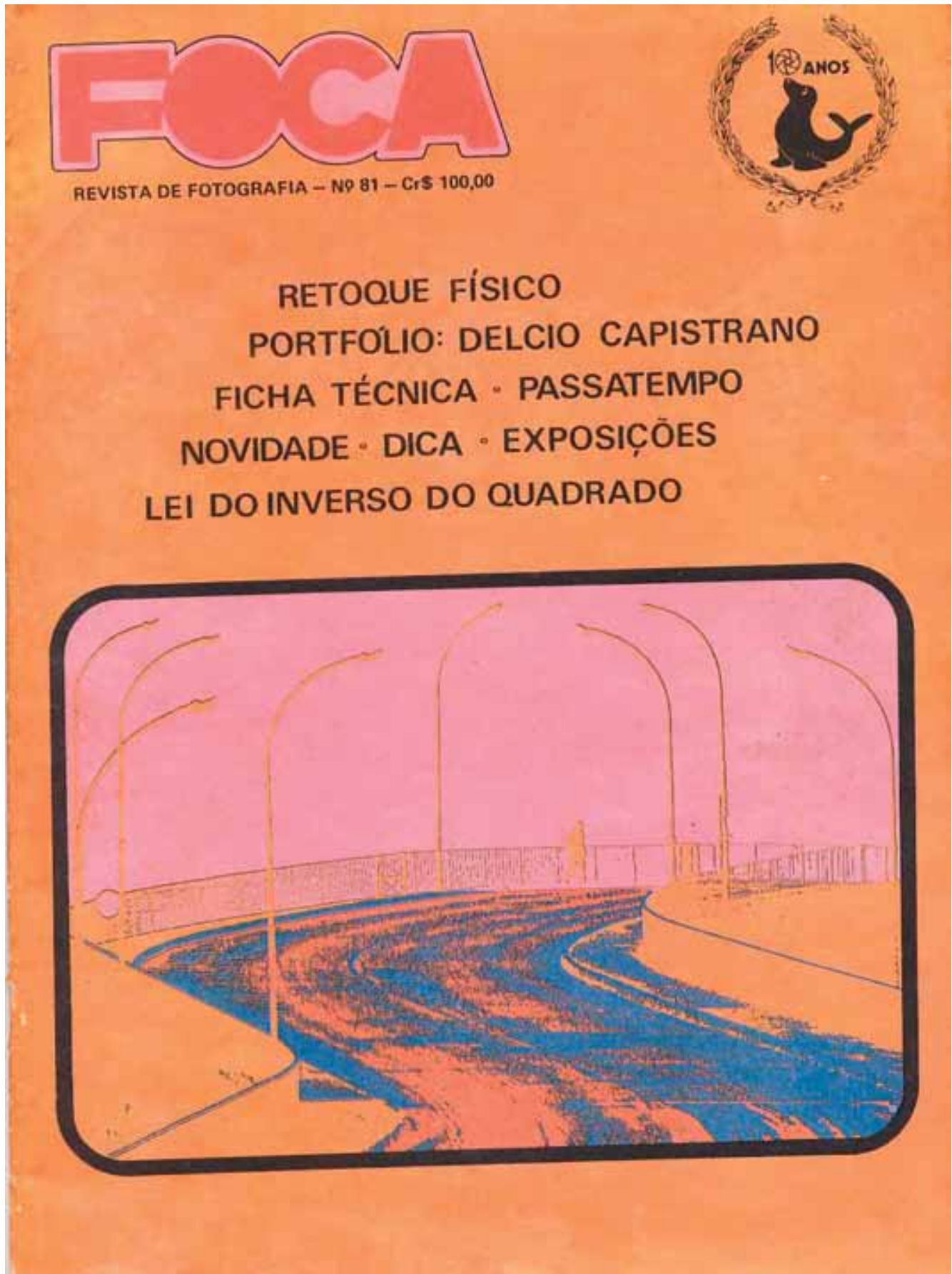

Figura 18 - Capa da revista Foca, nº 81, 1981. Acervo do Clube da Objetiva (CO), Goiânia. 


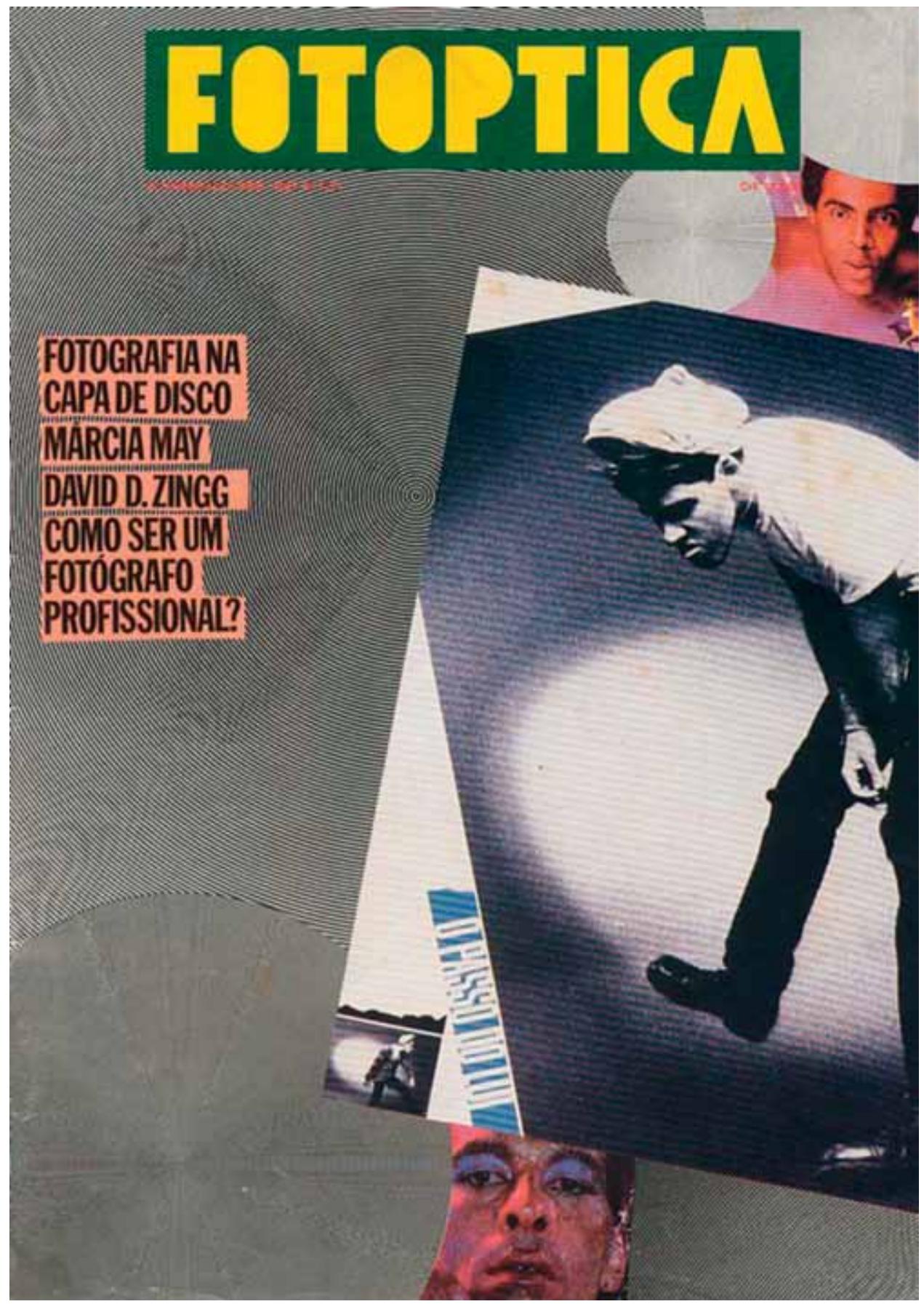

Figura 19 - Capa da revista Fotoptica, n 125, 1985. Acervo do Clube da Objetiva (CO), Goiânia. 
103. Ibidem

104. Cf. Jaffet Nacle Vieira (1978a); o texto em questão, na realidade, é uma tradução livre de Giovanni Campana, extraído da revista italiana Progresso Fotografico, publicada em Milão.

105. Délcio Capistrano iniciou sua carreira em 1971 , ano em que conquistou 7 prêmios em salões nacionais e internacionais. Recebeu diploma de Artista Fotográfico Brasileiro, concedido pela Confederação Brasileira de Fotografia e Cinema e pela Fédération Internationale de l'Art Photographique, com sede na Suíça.

106. Ver Foca (1981, p. 13-17).

107. Ver José Carlos Filizola (1978a; 1978b).

108. Ver Robert Pontual (1979).

109. Ver Jafet Nacle Vieira (1980).

110. Ver P. Ladetto (1988) a gênese da obra de arte, mesmo que o artista assim o pense. Forças profundas instigam a sua escolha deliberada e são essas que denunciam a sua sensibilidade da maneira a mais implacável103.

Além dessa ligação da arte com a criação, muito se fala sobre a marca pessoal do fotógrafo, que, junto com a afirmação anterior, o caracteriza como artista. Nesse sentido, Jafet Nacle Vieira, fotoclubista da ABAF, em boletim informativo do mês de maio de 1978, escreve um texto ${ }^{104}$, no qual defende que o estilo é marcado pela personalidade e, portanto, pode ser visto não só na experiência histórica, mas na seleção dos equipamentos fotográficos, nos conhecimentos, no caráter, nas ideias e convicções de cada um. Com isso, o estilo caracteriza e personaliza o trabalho de um fotógrafo.

Apesar disso, percebe-se que o fato de obterem-se imagens mediante um processo mecânico, com a câmera fotográfica, oferece dificuldades para a impressão de uma marca pessoal. Contudo, fatores ligados à experiência de vida (conhecimentos, sensibilidade e personalidade) e o momento político, social e cultural podem ir além dessa mecanicidade. Um exemplo de um fotógrafo-artista que imprime uma marca pessoal ao seu trabalho é o fotoclubista da ABAF, Délcio Capistrano ${ }^{105}$, que tem um trabalho voltado para retratos em $P \& B$, no qual interfere com solarização ou separação de tons. Ele teve um portfólio publicado na revista Foca ${ }^{106}$ (Figuras 20 a 24).

Essa marca pessoal, como se percebe até mesmo pelas imagens de Délcio Capistrano, é reforçada pelo uso de técnicas específicas. Vê-se que, na prática fotoclubista, em alguns momentos não há uma separação bastante clara entre arte e técnica e, em outros, parece não existir.

Por exemplo, na sessão Fotografia e Arte de dois boletins informativos da ABAF, o sócio José Carlos Filizola discute, respectivamente, acerca do ritmo na composição fotográfica e sobre contraste ${ }^{107}$.

Tal questão entre arte e técnica, por não ser consenso, abriu muito espaço para discussão nos boletins informativos dos clubes. É o que aponta um texto de Robert Pontual ${ }^{108}$, em que, considerando o período de 1978 a 1979, ele defende a existência de uma tendência, no Brasil, de se encarar a fotografia não apenas como técnica, mas também como linguagem. Para Jafet Nacle Vieira, "quando uma fotografia é boa (no sentido técnico e artístico), a forma não 'briga' com o conteúdo. Em outras palavras: a forma 'é' o conteúdo"109. Ou seja, o domínio técnico deve caminhar junto à expressão artística.

A discussão em relação à técnica aplicada à fotografia artística era promovida também nos fotoclubes internacionais, como o italiano II Fotoamatore, em que, em texto republicado no Boletim FCCB de maio de 1988, o autor parte da pergunta "Que peso dar à técnica na fotografia?"110. Deve-se, primeiro, distinguir "técnica de câmara" (sobre a câmera fotográfica enquanto equipamento ou aparato tecnológico, óptica, impressão de cópia) de "técnica estética" (preceitos de tomada e composição). E somente esses conhecimentos técnicos não são suficientes. É preciso partir de uma ideia, para, depois, utilizar meios técnicos e técnico-estéticos. E arremata afirmando: "acho que os fotógrafos não devem se 


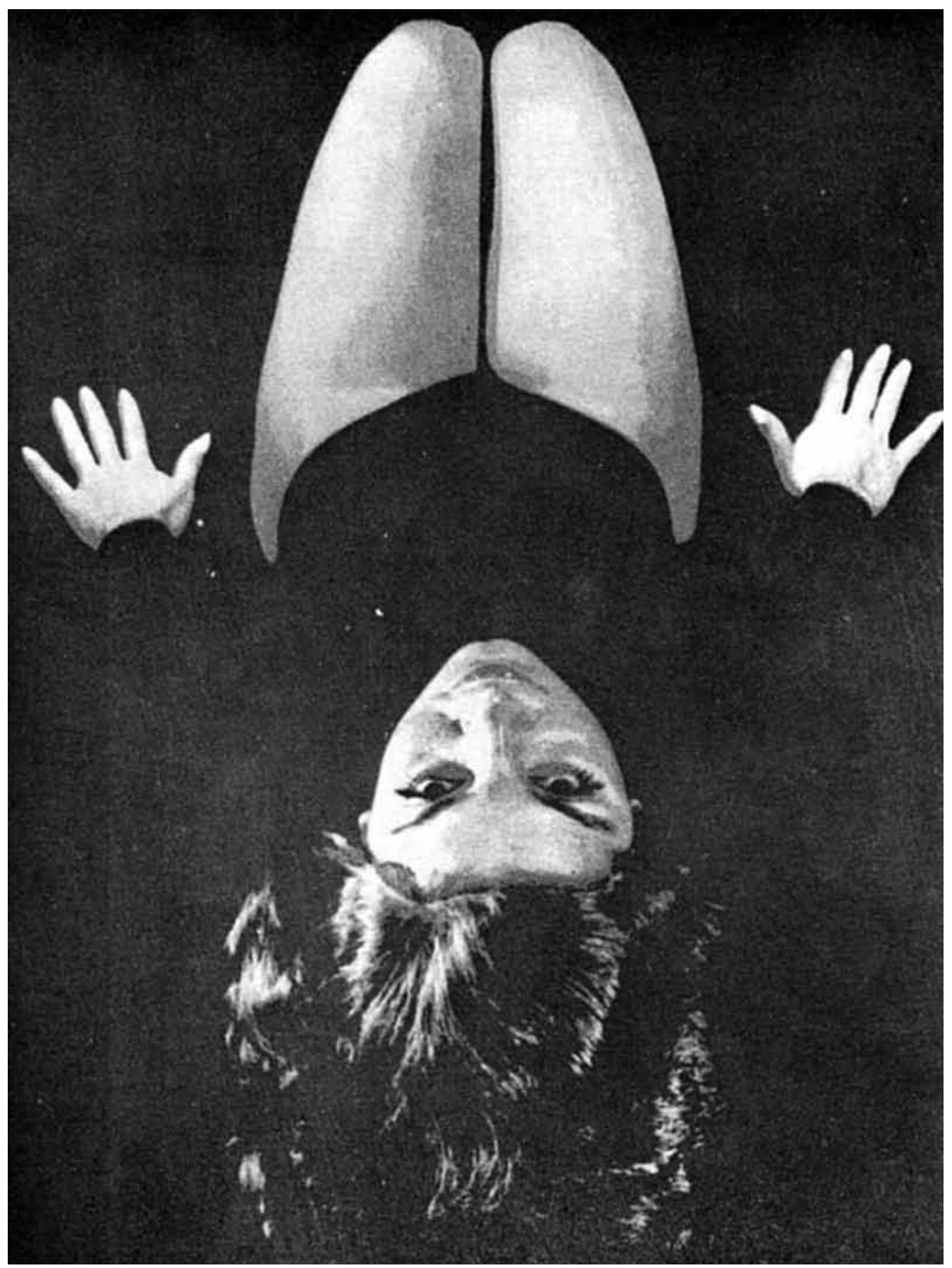

Figura 20 - Imagem integrante do conjunto de fotografias de Délcio Capistrano. Foca, São Paulo, $\mathrm{n}^{\circ} 81,1981$, p. 13-17. 


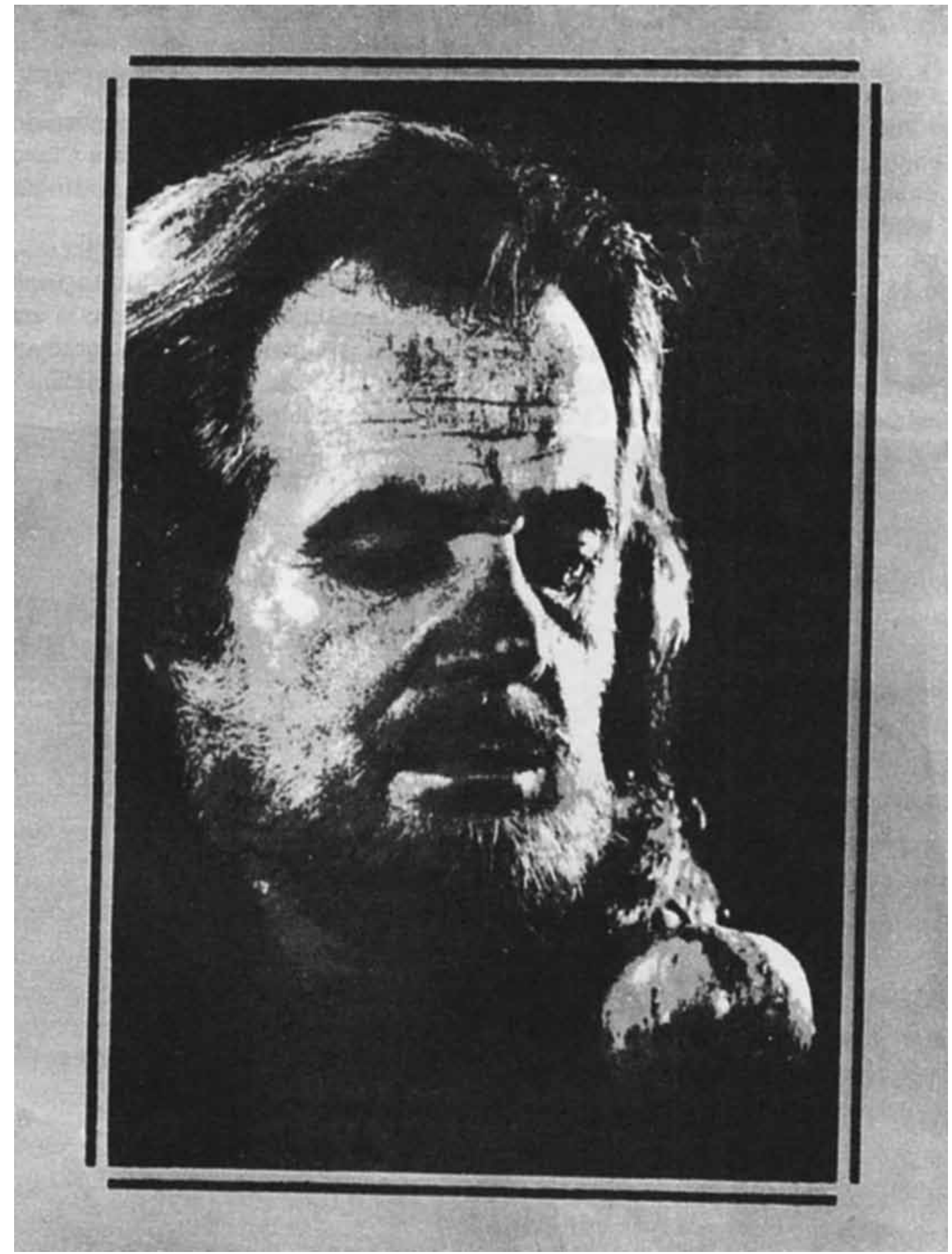

Figura 21 - Imagem integrante do conjunto de fotografias de Délcio Capistrano. Foca, São Paulo, no 81,1981, p. 13-17. 


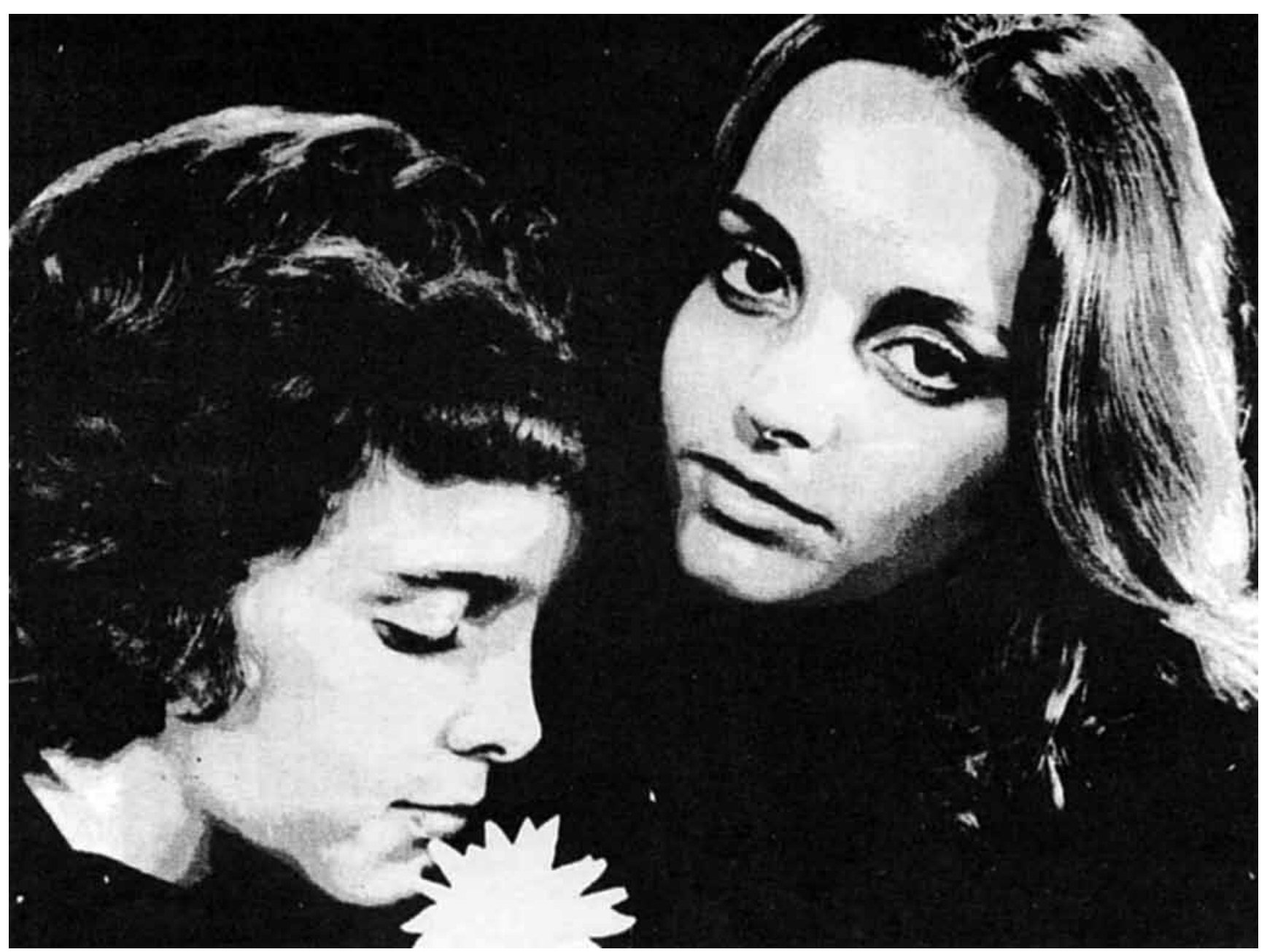

Figura 22 - Imagem integrante do conjunto de fotografias de Délcio Capistrano. Foca, São Paulo, no 81, 1981, p. 13-17. 


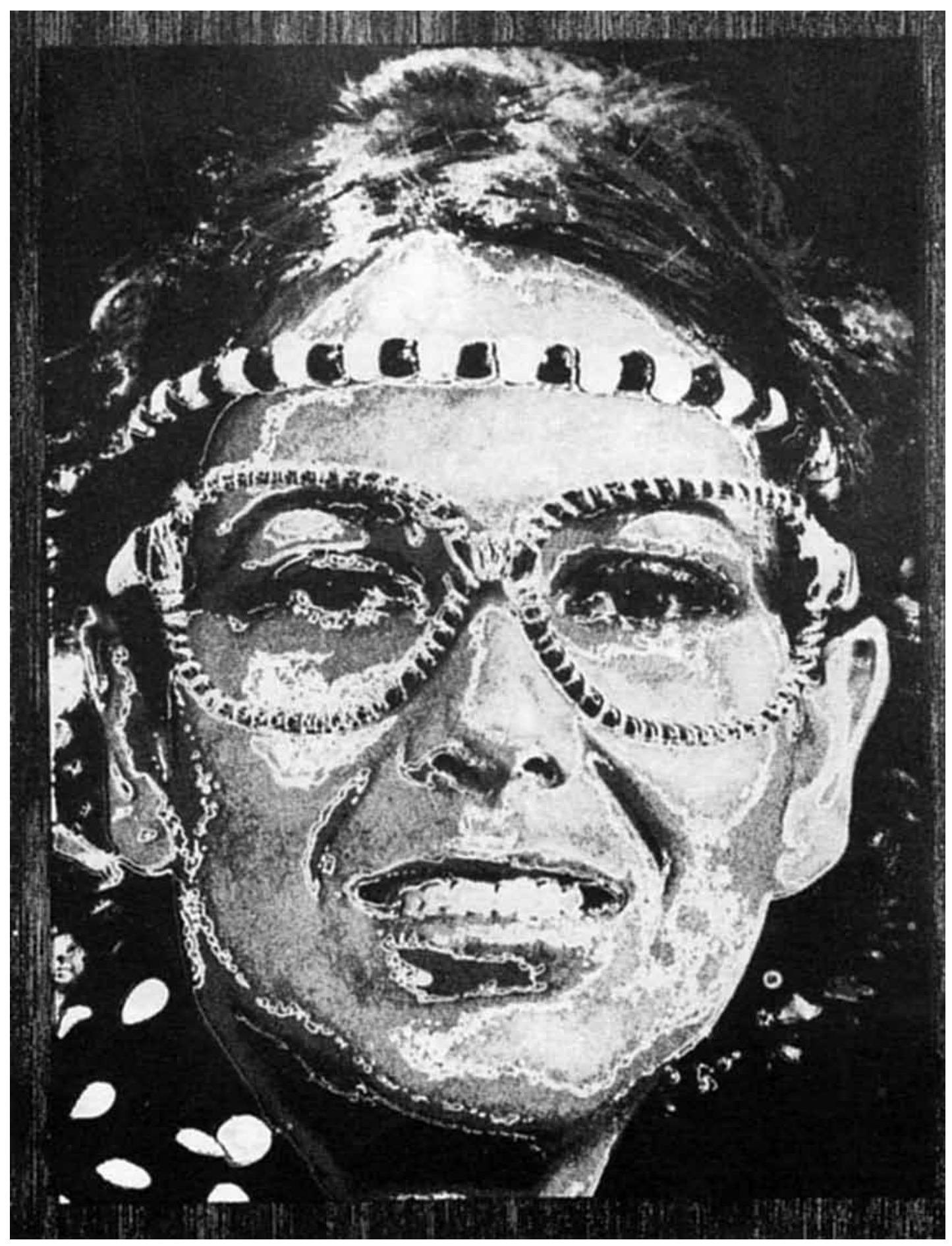

Figura 23 - Imagem integrante do conjunto de fotografias de Délcio Capistrano. Foca, São Paulo, ํo 81 , 1981 , p. 13-17. 


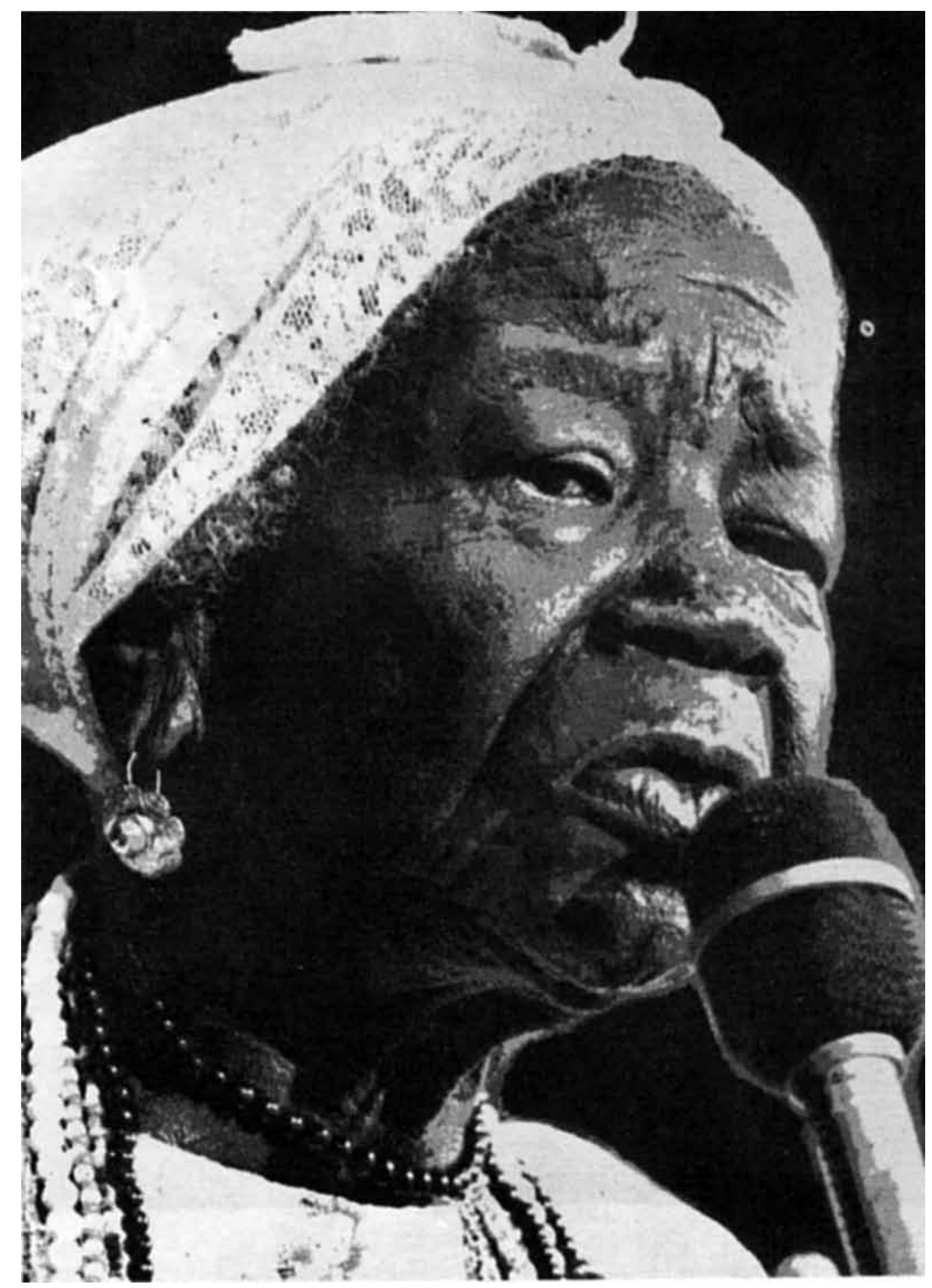

Figura 24 - Imagem integrante do conjunto de fotografias de Délcio Capistrano. Foca, São Paulo, no 81,1981, p. 13-17. 
111. Ibidem

112. Ver Aníbal Siqueira (1988).

113. Fotógrafo moderno, discípulo de Ansel Adams,

114. Cf. Minor White (2003, p. 250)

115. Ver Ricardo Zwecker (1987).

116. Ver Renzo Bruni (1985).

117. Alfred Stiglietz apud Rodrigo Torres Costa (2006, p. 49). tornar escravos de uma técnica, mas saber perguntar, antes de qualquer outra consideração, o que pretendo obter com o aparelho fotográfico?" 111

Com relação ao que Ladetto defende sobre a ideia antes de fotografar, Aníbal Siqueira, esboça uma concordância ${ }^{112}$, em que debate sobre $\mathrm{o}$ ato de fotografar, que se origina com o olhar atento, emocionado e criativo, captando a imagem, a matriz original. Depois, a câmera escura pode criar e recriar a imagem fotográfica, originada na imagem mental. Nesse sentido o fotógrafo Minor White ${ }^{113}$ diz que a fotografia deve funcionar pela seguinte equação: "Fotografia + Pessoa olhando = Imagem Mental" 114 .

Também Ricardo Zwecker ${ }^{115}$ expõe essa necessidade de se pensar na imagem fotográfica antes mesmo de fazê-la, com o argumento de que quem não procede dessa maneira não conhece os fundamentos da arte. Logo, a arte fotográfica estaria ligada ao pensamento conectado ao sentimento, sendo estes anteriores ao ato fotográfico de Siqueira ou à técnica, tanto a "técnica de câmara" quanto a "técnica estética" de Ladetto.

Esse "pensar" fotográfico pode ser utilizado por qualquer fotógrafo, contudo só o fotoclubista, também chamado fotoamador, pode fazê-lo livremente. Isso porque, só se é um fotoamador quando, liberto de quaisquer vínculos, se dá expansão aos próprios desejos. "Ser fotoamador é um estado de alma: o de experimentar, divertir-se com a câmara fotográfica e com os processos, sentir-se livre para realizar qualquer coisa sem conhecer aonde o levará o caminho empreendido." 116 .

Sobre o fotoamadorismo Alfred Stiglietz, completa o que Bruni expõe:

Permitam-me chamar a atenção para um dos mais frequentes erros que se comete quando se trata de fotografia: o erro de se classificar trabalhos de alto nível como profissionais e usar o termo amador para transmitir a ideia de produção imatura e para desculpar fotografias pobres e detestáveis. Na realidade, quase todos os trabalhos de alto nível estão sendo feitos - sempre foram feitos - por aqueles que estão seguindo seu amor pela fotografia, e não meramente por razões financeiras. Como o nome subentende, o amador é aquele que trabaIha por amor; e, visto sob este ângulo, o erro da classificação popular fica totalmente aparente ${ }^{17}$.

Apesar de o ambiente fotoclubista gerar tal fotoamador, Bruni, alerta para a diminuição de sua quantidade, pois o espaço que deveria dar livre expansão à criatividade e ser uma derivação dela, está se transformando em um estado de ânimo próximo ao dos profissionais, no que tange à participação em concursos e salões. Para ele, isso se deve ao fato de não estar mais a realização das fotografias ligada ao próprio gosto, mas à busca de se agradar um júri, ao "gosto da moda", "ao gosto do cliente". Para ele, isso representa um risco à liberdade de cada amador, já que abdica de sua própria expressividade.

A livre expressão, que caracteriza o fotoamador, deve ser exercida pelo fotógrafo desde que através da fotografia seja transmitida uma ideia, e isso assume grande importância na fotografia artística. Eduardo Salvatore argumenta que o primeiro elemento de uma criação artística é a transmissibilidade, pois sem 
isso não há comunicação com a obra de arte; e questiona: "que valor poderá ter uma obra se ela for tão hermética que só tem sentido para o próprio autor?"1118.

Para Salvatore, uma obra de arte deve conter ideia e emoção, com elementos capazes de proporcionar transmissibilidade, ainda que seja para um público mais restrito e especializado. Tanto que é possível realizar obras tecnicamente perfeitas sem serem consideradas obras de arte, não passando de exercícios experimentais.

Assim, para ser considerada artística, ou seja, uma obra de arte, uma fotografia deve conter elementos estéticos capazes de transmitir uma ideia, uma sensação, uma emoção, por meio de elementos que falem mais ao espírito que aos olhos do observador.

Com todos esses conceitos colocados até aqui sobre a definição de arte fotográfica na prática fotoclubista, conclui-se, adotando pensamento de Salvatore, de que "fotos artísticas são realmente produto de uma visão e interpretação pessoal do autor, quando não de sua inteira concepção"119.

Para ele, o que caracteriza a obra de arte é a essência pessoal do artista refletida na escolha do assunto e no seu tratamento, que engloba, entre outros fatores, o desenho ou arranjo composicional, o ponto de vista, as cores e, por último a técnica. Deve ser mencionada, ainda, a motivação para criar, que pode ter origem em uma disposição visual ou mesmo ser íntima ou psíquica.

Com a discussão dessas questões nos textos publicados em boletins informativos, revela-se a postura, dos fotoclubes, de evidenciar para seus sócios os parâmetros que norteiam uma fotografia artística, embora não se mencione, em nenhum momento, a existência da concepção de uma estética moderna.

Contudo, pode-se dizer que os conceitos presentes na fotografia moderna tomam forma na produção fotográfica dos fotoclubes das décadas de 1970 e 1980, como se verifica pelo paralelo antes traçado, em que são mostradas imagens de diversos fotoclubes do país e algumas selecionadas pelo Clube da Objetiva para os seus salões. Ou seja, mesmo não havendo uma discussão profunda e que ligue diretamente a essa estética, ela, imageticamente, assim como o pictorialismo, também caracteriza o movimento fotoclubista.

Os salões de fotografia eram os grandes expoentes dessa fotografia, caracterizada pelo fotoclube como artística:

Atualmente aqui no Brasil a fotografia está começando a ter aceitações como obra de arte, haja visto [sic] o aparecimento de cada vez mais salões nacionais e internacionais de Arte Fotográfica. Nos últimos anos Goiânia tem se engajado neste processo e já está podendo se equiparar aos valores dos grandes centros culturais do País. [...] Os salões de arte fotográfica fazem muito em prol do crescimento do artista. No Brasil temos muitos salões nacionais e internacionais, inclusive em Goiânia já organizamos o 1. Salão Nacional de Arte Fotográfi$\mathrm{ca}$, que obteve uma grande performance. Acredito que toda pessoa que goste e se dedique à fotografia deva participar destes salões de arte, pois são eles uma amostragem do que se faz de mais atual no campo fotográfico ${ }^{120}$.

Vê-se que, apesar do intervalo de tempo em relação ao início da estética moderna, ela ainda deu forma ao movimento fotoclubista nas décadas
118. Ver Eduardo Salvatore (1987b).

119. Cf. Eduardo Salvatore (1988g, p. 5).

120. Rosary Esteves apud Odessa Hermano (1978)

Annals of Museu Paulista. v. 18. n.2. July.-Dec. 2010. 
121. Cf. Helouise Costa e Renato Rodrigues da Silva (2004, p. 147)

122. Idem, p.111.

123. Cf. Antônio Augusto de Araújo Sá (1979, p. 2).

124. Informações dispooníveis em: <www.confoto.art. br>.

125. Ver Eder Chiodeto (2006).

126. Dessas 140 fotografias, 4 eram do CO. Três de autoria de Regina Esteves: $\mathbf{M u}$ lher maravilha (menção honrosa), Mesquita, e Cochicho; e uma de Paulo Fonseca: Ruínas.

127. Dessas 66 fotografias, duas eram do CO: Mãe alimento, de Cidinha Coutinho, e Sem Título, de Rosary Esteves. de 1970 e 1980, com a definição de um conceito peculiar para a fołografia artística. Entretanto, os conceitos ficam distanciados do que a história da Arte denomina como arte fotográfica deste período, ligada à ruptura em relação à arte acadêmica.

Contexto atual da produção fotoclubista

Com a ascensão do fotojornalismo, em que o fotógrafo participa direta e imediatamente do mundo, dissemina-se uma estética em que a gratuidade do fotoclubismo não se encaixa. Com isso, em meados de 1960, há uma perda de espaços conquistados nas décadas anteriores e, consequentemente, da importância social desse movimento. Acrescente-se que a produção dos fotoclubistas se tornou anacrônica diante de novas questões culturais que se apresentavam ${ }^{121}$.

Apesar de considerar-se o declínio do movimento fotoclubista, em decorrência da redefinição das práticas fotográficas, apontadas pelo fotojornalismo e pela fotopublicidade, a atuação dos fotoclubes ainda persiste. Neste sentido, Helovise Costa e Renato Rodrigues da Silva apontam que essas associações "vivem da lembrança do seu passado, das antigas glórias vividas e do sonho de retornar aos bons velhos tempos - que não voltam mais" 122.

Entretanto, muitos fotoclubistas não concordam com essa condição de decadência do movimento, como Antônio Augusto de Araújo Sá, que em 1979 foi presidente da Associação Brasileira de Fotografia (Abaf-R): "O Foło Clube está cada vez mais vivo não só no Brasil como em todo mundo e podemos constatar isso, pelo número de novos fotoclubes no Brasil e em vários países e pelos salões nacionais e internacionais no mundo inteiro" 123 .

Contudo, há registro, na Confederação Brasileira de Fotografia ${ }^{124}$, de que essas associações quase deixaram de existir após a década de 1960, chegando apenas a 14 entidades. Há dados indicando que, hoje, existem em torno de 40 fotoclubes no Brasil, dos quais 33 fazem parte da Confederação ${ }^{125}$. Para Chiodeto, autor da matéria, esse novo impulso do fotoclubismo pode ser consequência da existência de novas tecnologias e do fácil acesso a elas, o que possibilita uma retomada dessa prática.

A fim de mostrar este retorno da prática clubista no cenário cultural brasileiro, foram realizadas no mês de junho e julho de 2006, no Museu da Imagem e do Som de São Paulo, duas exposições. No primeiro andar, ocorreu a 24. Bienal de Arte Fotográfica Brasileira em Preto e Branco, composta por 140 fotografias ${ }^{126}$ que mostram a produção recente de cerca de 33 fotoclubes brasileiros. No segundo andar, 66 imagens ${ }^{127}$ apontavam para uma retrospectiva dos fotoclubistas dos anos 1940 a 1970.

Apesar da defasagem temporal entre o primeiro e segundo andar, Eder Chiodeto afirma que "na mostra do primeiro andar a estética dominante ainda presta um tributo a essas práticas. $\bigcirc$ fazer fotográfico dos fotoclubes parece 
irremediavelmente atrelado a uma linguagem que sofre pouca variação no tempo. A ruptura se tornou tradição" 128 .

Com a afirmação de Chiodeto e as fotografias apresentadas na exposição, percebe-se que a decadência do movimento fotoclubista colocada por alguns autores talvez se deva à ausência de experimentação, característica da prática desenvolvida desde os anos 1940 e não propriamente pela diminuição do número de fotoclubes.

É nesse contexto de "decadência" do movimento fotoclubista que, no estado de Goiás, na década de 1970, surge em Goiânia o Clube da Objetiva, fundado por um grupo de entusiastas da fotografia. Como, então, este fotoclube e outros do período trabalharam visualmente suas imagens?

fotoclubismo, nos níveis internacional e nacional, nasce da estética pictorialista. Da crítica ao pictorialismo surge o modernismo, havendo pouca variação na prática fotoclubista desde então, como assinala Chiodeto ${ }^{129}$.

Mesmo não sendo mencionada a estética moderna, ou mesmo o pictorialismo, na prática fotoclubista, eles permeiam, em termos imagéticos, a produção fotográfica. Como não há uma discussão acerca disso e, assim, uma consciência clara por parte dos fotoclubistas, tais estéticas não aparecem de forma separada.

Com isso é possível pensar em uma "estética em trânsito", ou seja, uma estética de "natureza híbrida, fronteriça e tranversal"130, que está balizada pela visualidade dos salões de arte fotográfica. $\bigcirc$ Clube da Objetiva, tendo sido seletor das imagens nos cinco salões que organizou contribuiu também para a construção dessa visualidade do fotoclube no Brasil.

\section{REFERÊNCIAS}

LIVROS, PERIÓDICOS, BOLETINS

ASBORNO, Carlos R. Concursos internos. Boletim FCCB, São Paulo, nov. 1987.

AZEREDO, Rachel. Ladrões impediram a mostra de fotografia. O Popular, Goiânia, 7 out. 1977.

BARBI, G. O retrato. Boletim FCCB, São Paulo, abr. 1988.

BARTHES, Roland. A câmera clara: nota sobre fotografia. Rio de Janeiro: Nova Fronteira, 1984.

BENJAMIM, Walter (Org.). A pequena bistória da fotografia. In: Paulo: Brasiliense, 1994. p. 91-115.

BOLETIM Clube Foto Amigos, Santos, v. 6, n. 44, jul. 1979.

BOLETIM Clube Foto Amigos, Santos, v. 5, n. 53, jun. 1980.

BOLETIM Clube Foto Amigos, Santos, v.8, n. 69, nov. 1981.

BRUNI, Renzo. O Fotoamador. Boletim FCCB, São Paulo, jul. 1985.
128. Ver Eder Chiodeto (2006).

129. Ibidem

130. Cf. José Luis Molinuevo (2002, p. 17) 
CHIODETO, Eder. Ruptura e tradição se encontram no MIS. Folba de São Paulo, São Paulo, 24 jun. 2006, E4.

CIRCULAR da CBFC, Rio de Janeiro, jan.-mar. 1988.

CLUBE DA OBJETIVA (Goiânia, GO). Salão de Arte Fotográfica de Goiás, 1: catálogo. Goiânia, 1972.

Salão Nacional de Arte Fotográfica, 1: catálogo. Goiânia, 1977.

Salão Nacional de Arte Fotográfica, 2. catálogo. Goiânia, 1978.

Salão Nacional de Arte Fotográfica, 3. catálogo. Goiânia, 1980.

Salão Nacional de Arte Fotográfica, 4. catálogo. Goiânia, 1981.

Salão Nacional de Arte Fotográfica, 5. catálogo. Goiânia, 1987.

COSTA, Helouise. Fotografie und Modernismus in Brasilien: Anmerkungen zu einer einzigartigen Avantgard [Fotografia e modernismo no Brasil: a propósito de uma vanguarda singular]. In: DRESSEL, Helga. Zeitgenössische Fotokunst aus Brasilien [Arte fotográfica contemporânea do Brasil]. Berlim: Braus, 2006. p. 144-148.

COSTA, Helouise; SILVA, Renato Rodrigues da. A fotografia moderna no Brasil. São Paulo: Cosac \& Naify, 2004.

COSTA, Leila Daher. Clube da Objetiva: quando fotografar é uma arte. O Popular, Goiânia, [s.d.].

COSTA, Rodrigo Torres. Fotografia como arte ou arte como fotografia? Fotógraphos, v. 2, n. 8, p. 13-17, 2006.

CRUZ, Tadeu J. Definição da natureza. Boletim FCCB, São Paulo, jul. 1985.

DELLAYE, F. A necessidade de um sentimento estético. Boletim FCCB, São Paulo, out. 1988.

DENZIN, Norman K. Interpretive ethnography: ethnographic practices for the $21^{\text {st }}$ century. Thousand Oaks: Sage, 1997.

DUBOIS, Philippe. O ato fotográfico e outros ensaios. Campinas: Papirus, 1993.

EDITORIAL. Os "problemas" dos salões de arte fotográfica. Boletim FCCB, São Paulo, out. 1987. Por uma nova modernidade. Boletim FCCB, São Paulo, jun. 1988. As lições de Yousuf Karsh. Boletim FCCB, São Paulo, dez. 1988.

ESPADA, Heloísa. Panamericanismo e straight photography como impulsos da fotografia moderna paulistana. Boletim [Grupo de estudos do Centro de Pesquisas em arte e fotografia do Departamento de Artes Plásticas ECA-USP], São Paulo, n. 1, p. 48-57, 2006.

FATORELLI, Antônio. Fotografia e viagem: entre a natureza e o artifício. Rio de Janeiro: Relume Dumará; Faperj, 2003.

FELÍCIO, Brasigóis. Tiokô para os destaques. O Popular, Goiânia, 25 set. 1987. 
FILIZOLA, José Carlos. Fotografia e arte. Boletim Abaf, Rio de Janeiro, jan. 1978a. Fotografia e técnica. Boletim Abaf, Rio de Janeiro, abr. 1978b. . Fotografia e arte. Boletim Abaf, Rio de Janeiro, maio 1978c.

FOCA, Revista de Fotografia, São Paulo, v. 11, n. 80, ago. 1981a. v. 11, n. 81 , set. $1981 b$. , v. 11, n. 84, ago. $1981 \mathrm{c}$.

FOTOARTE, Rio de Janeiro, n. 178, 1973. , n. 189, 1974. n. 192,1974 .

FOTOPTICA, São Paulo, n. 125, set.-out. 1985.

GIBSON, Andrew J. F. A Fiap define fotografia da natureza. Boletim FCCB, São Paulo, jul. 1988. HERMANO, Odessa. [Entrevista de Rosary Esteves]. Top News, Goiânia, 23-30 jan. 1978. . Clube da Objetiva e outras. Top News, Goiânia, 15-21 abr. 1979. [Sem título]. Top News, Goiânia, 1-6 abr. 1980.

J.C.S. A foto experimental. Boletim FCCB, São Paulo, ago, 1988.

KOSSOY, Boris. O relógio de Hiroshima: reflexões sobre os diálogos e silêncios das imagens. Revista Brasileira de História, São Paulo, v. 25, n. 49, p. 35-42, 2005.

LADETTO, P. Técnica e estética. Boletim FCCB, São Paulo, maio 1988. MACHADO, Arlindo. A ilusão especular. Rio de Janeiro: Funarte, 1984.

MAGALHÃES, Ângela; PEREGRINO, Nadja. Fotografia no Brasil: um olhar das origens ao contemporâneo. Rio de Janeiro: Funarte, 2004.

MELO, Maria Teresa Bandeira de. Arte e fotografia: o movimento pictorialista no Brasil. Rio de Janeiro, Funarte, 1998.

MOLINUEVO, José Luis. La experiencia estética moderna. Madrid: Sintesis, 2002.

NERY, Olavo. Fotografia e arte. Boletim Abaf, Rio de Janeiro, nov.-dez. 1977.

OLIVEIRA, Eliézer Cardoso de. História cultural de Goiânia. Goiânia: Alternativa, 2003.

PEDRO, Vicente João. O momento atual da fotografia. O Popular, Goiânia, 11 set. 1977, Caderno 2. PERMUTH, Mário. Auto Crítica. Boletim FCCB, São Paulo, set. 1985. 
POLACOW, Jacob. Arte fotográfica em seus aspectos locais. Studium, Campinas, 1-3; disponível em: <www.studium.iar.unicamp.br>.

PONTUAL, Roberto. Fotografar: um modo de ver. Boletim Abaf, Rio de Janeiro, abr. 1979.

ROUILLÉ, André. Historia de la fotografía. Barcelona: Martínez Roca, 1986.

SÁ, Antônio Augusto de Araújo. Foto Clube: Salões de Fotografia. Boletim Abaf, Rio de Janeiro, ago. 1979.

SALVATORE, Eduardo. A crítica fotográfica. Boletim FCCB, São Paulo, set. 1987

.Considerações à margem do 39. Salão de Fotografias. Boletim FCCB, São Paulo, set. 1987.

. Em busca de uma estética fotográfica. Boletim FCCB, São Paulo, nov. 1987.

. Um preconceito tolo. Boletim FCCB, São Paulo, jan. 1988a.

_. A fotografia abusiva. Boletim FCCB, São Paulo, mar. 1988 b.

O nu, em fotografia. Boletim FCCB, São Paulo, abr. 1988c.

Criticando a crítica. Boletim FCCB, São Paulo, maio 1988d.

História e tradições. Boletim FCCB, São Paulo, jun. 1988e.

O primeiro fotoclube do Brasil. Boletim FCCB, São Paulo, jul. 1988f.

—. A fotografia artística. Boletim FCCB, São Paulo, ago. 1988g.

. Os novos "descobridores". Boletim FCCB, São Paulo, set. 1988h.

Considerações sobre o movimento fotográfico. Studium, Campinas, 1-3; disponível em: <www.studium.iar.unicamp.br>.

SOBRINO, Vanessa. Crítica fotográfica no Boletim do Foto-cine Clube Bandeirante, 1948-1953. Studium, Campinas; disponível em: <www.studium.iar.unicamp.br>.

SCHAEFFER, Jean-Marie. A imagem precária: sobre o dispositivo fotográfico. Campinas: Papirus, 1996.

SEGISMUNDO. Para ser um bom julgador... Boletim FCCB, São Paulo, jul. 1988.

SEQUEIRA, Aníbal. O ato fotográfico. Boletim FCCB, São Paulo, jun. 1988.

SONTAG, Susan. Sobre fotografia. São Paulo: Companhia das Letras, 2004.

STIEGLITZ, Alfred. Pictorial photography. In: PHILIPPI, Simone (Ed.). Camera work: the complete illustrations 1903-1917. New York: Taschen, 1997. p. 351-357.

STRAND, Paul. La motivación artística em fotografía (1923). In: FONTCUBERTA, Joan (Org.). Estética fotográfica: una selección de textos. Barcelona: Gustavo Gili, 2003. p. 105-120. 
Photography. In: PHILIPPI, Simone (Ed.). Camera work: the complete illustrations 1903-1917. New York: Taschen, 1997. p. 780-781.

TALBOT, Willian Henry Fox. El lápiz de la naturaleza (1846). In: FONTCUBERTA, Joan (Org.). Estética fotográfica: una selección de textos. Barcelona: Gustavo Gili, 2003. p. 49-51.

VIEIRA, Jafet Nacle. O estilo é o homem: a marca registrada. Boletim Abaf, Rio de Janeiro, maio 1978 .

O "encontro" criativo. Boletim Abaf, Rio de Janeiro, ago. $1978 \mathrm{~b}$.

Técnica e Talento. Boletim Abaf, Rio de Janeiro, ago. 1980.

WESTON, Edward. Viendo fotograficamente (1943). In: FONTCUBERTA, Joan (Org.). Estética fotográfica: una selección de textos. Barcelona: Gustavo Gili, 2003. p. 245-251.

WHITE, Minor. El ojo y la mente de la cámara (1952). In: FONTCUBERTA, Joan (Org.). Estética fotográfica: una selección de textos. Barcelona: Gustavo Gili, 2003. p. 237-244.

Equivalencia: tendencia perpetua (1963). In: FONTCUBERTA, Joan (Org.). Estética fotográfica: una selección de textos. Barcelona: Gustavo Gili, 2003. p. 245-155.

ZAYAS, Marius de. Photography and artistic-photography. In: PHILIPPI, Simone (Ed.). Camera work: the complete illustrations 1903-1917. New York: Taschen, 1997. p. 709-711.

ZWECKER, Ricardo. Uma pequena reflexão fotográfica. Boletim FCCB, São Paulo, out.1987.

SITES

<www.abaf.art.br>, acesso em dez. de 2005.

<www.confoto.art.br>, acesso em abr. de 2006.

<www.folha.com.br>, acesso em jun. de 2006.

<www.fotoclub.art.br>, acesso em jan. de 2006.

<www.irisfotogrupo.hpg.ig.com.br>, acesso em dez. de 2005.

<www.studium.iar.unicamp.br>, acesso em abr. de 2006.

\section{DEPOIMENTOS PESSOAIS}

ASSIS, Décio Marmo de. Depoimento [maio 2006]. Entrevistadora: Ana Rita Vidica Fernandes, Goiânia, 2006.

ESTEVES, Rosary. Depoimento [maio 2006]. Entrevistadora: Ana Rita Vidica Fernandes, Goiânia, 2006.

ESTEVES, Ruy. Depoimento [set. 2006]. Entrevistadora: Ana Rita Vidica Fernandes, Goiânia, 2006. 
HERMANO. Odessa Arruda. Depoimento [jun. 2006]. Entrevistadora: Ana Rita Vidica Fernandes, Goiânia, 2006.

MENEZES, Amaury. Depoimento [mar. 2006]. Entrevistadora: Ana Rita Vidica Fernandes, Goiânia, 2006.

PACHECO, Lurdinha. Depoimento [out. 2006]. Entrevistadora: Ana Rita Vidica Fernandes, Goiânia, 2006.

SOUZA, Sílvia de. Depoimento [ago. 2006]. Entrevistadora: Ana Rita Vidica Fernandes, Goiânia, 2006.

VASCONCELlOS, Luis Mauro. Depoimento [jun. 2006]. Entrevistadora: Ana Rita Vidica Fernandes, Goiânia, 2006.

CARTAS

Carta enviada ao prefeito de Goiânia, Dr. Manoel dos Reis e Silva, 27 fev. 1973.

Carta recebida da Federação do Comércio de Goiás, 29 ago. 1979.

Carta enviada ao CFAS, 1988.

Artigo apresentado em 2/2010. Aprovado em 5/2010. 